
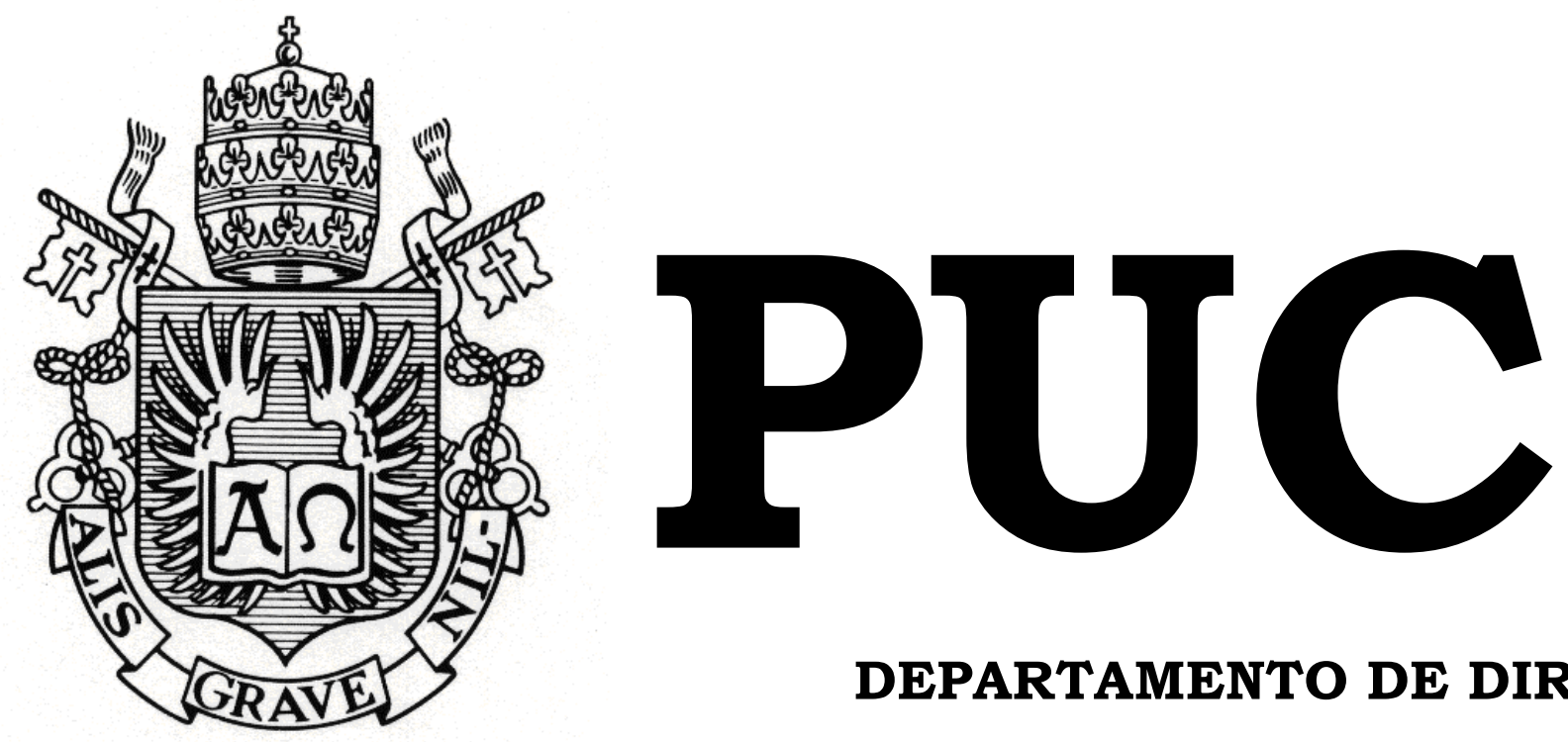

DEPARTAMENTO DE DIREITO

\title{
A INTERVENÇÃO DO ESTADO NO DOMÍNIO ECONÔMICO E O REGIME JURÍDICO DOS CONTRATOS DA PETROBRAS
}

por

ANDRÉ RIBEIRO TOSTA

ORIENTADORA: MARIANNA MONTEBELLO WILLEMAN 2014.2

PONTIFÍCIA UNIVERSIDADE CATÓLICA DO RIO DE JANEIRO

RUA MARQUÊS DE SÃO VICENTE, 225 - CEP 22453-900

RIO DE JANEIRO - BRASIL 


\title{
A INTERVENÇÃO DO ESTADO NO DOMÍNIO ECONÔMICO E O REGIME JURÍDICO DOS CONTRATOS DA PETROBRAS
}

\author{
por
}

ANDRÉ RIBEIRO TOSTA

Monografia apresentada ao

Departamento de Direito da

Pontificia Universidade Católica do Rio de Janeiro (PUC-Rio) para a obtenção do Título de Bacharel em Direito.

Orientadora: Marianna Montebello Willeman 


\section{AGRADECIMENTOS}

A monografia, para seu autor, representa muito mais do que o produto de meses de pesquisas extensivas e de horas de trabalho. Ela representa, na verdade, o final de um ciclo, a passagem de uma fase para outra, a certidão de óbito definitiva da infância e a certidão de nascimento da maturidade. Não se trata exclusivamente de um documento acadêmico, muito embora seja esse seu propósito formal.

Os desafios que serão vividos daqui para frente serão inteiramente diversos daqueles que enfrentamos no passado e, ao mesmo tempo que há um medo inegável do desconhecido e do abandono da zona de conforto com a qual nos acostumamos por tanto tempo, a sensação de ansiedade para enfrenta-los se desenvolve progressivamente. Por isso, não considero fútil uma seção de agradecimentos que vá evidenciar o quanto o suporte de diversas pessoas se fez marcante ao longo de todo esse período e que seguramente será imprescindível para o novo paradigma que se aproxima.

Trata-se de tarefa extremamente difícil elencar todos aqueles que nos transformaram e que nos moldaram ao longo do tempo, mas a realidade é que a vida é um grande processo de trocas; em cada nova experiência, em cada nova amizade, ou mesmo em cada nova inimizade, tomamos um pouco para nós e deixamos um pouco de nós, o que significa que, para ser justo, eu seria obrigado a listar cada pessoa com quem já me relacionei, exercício evidentemente impossível.

Assim, com a certeza de que deixarei alguns de fora, mas ao mesmo tempo na tentativa de ser econômico, seguem os agradecimentos.

Em primeiro lugar, agradeço à minha família que, para minha sorte, conta com dois núcleos igualmente importantes e cuja dedicação à minha educação e felicidade é incondicional. Minha mãe Regina Lúcia, meu irmão Gustavo e meu padrasto Sérgio. Meu pai Paulo Roberto e minha madrasta Florys. Eu não seria 
nada sem seu amor, carinho, conselho e, por que não, sem as eventuais discussões. Amo a todos.

Agradeço aos meus amigos da Escola Alemã Corcovado, que, em muitos casos, me acompanham há mais de 10 anos e cujos nomes eu não vou citar por apreço à paciência do leitor.

Agradeço aos meus amigos do clube Piraquê, cuja influência positiva na minha vida me engrandece a cada encontro e a cada constante e sincero gesto de afeto.

Agradeço aos meus amigos de golfe pelas constantes risadas e pelos memoráveis eventos que me proporcionaram.

Agradeço aos colegas de faculdade que se imiscuíram junto a mim nessa longa jornada lado a lado, ajudando sempre que possível.

Agradeço postumamente a Nelson Nascimento Diz, seguramente o principal responsável direta e indiretamente pela minha escolha pelo direito.

Agradeço a Luís Roberto Barroso por ter me iniciado na carreira profissional dentro de Direito Público, matéria com a qual me identifiquei prontamente e na qual pretendo seguir, e também pela sua irrefutável contribuição para os estudos nessa área que certamente influenciaram em muito o presente trabalho.

Agradeço aos colegas do Escritório Barroso Fontelles, Barcellos \& Mendonça, cujas contribuições para a minha vida profissional e acadêmica, não só, mas, sobretudo no campo jurídico, são incomensuráveis.

Agradeço, finalmente, à minha orientadora, Marianna Montebello Willeman, por estar sempre à disposição para debates acadêmicos objetivando, acima de tudo, o meu crescimento, além da constante motivação, não só para a realização do presente estudo, mas para o estudo do Direito em geral.

Enfim, para aqueles que não se sentiram representados com os agradecimentos acima, mas que sentem ter participado positiva ou negativamente da minha vida, agradeço a vocês também.

Muito obrigado! 
"Human progress is neither automatic nor inevitable. Every step toward the goal of justice requires sacrifice, suffering, and struggle; the tireless exertions and passionate concern of dedicated individuals".

- Martin Luther King Jr. 


\section{SUMÁRIO}

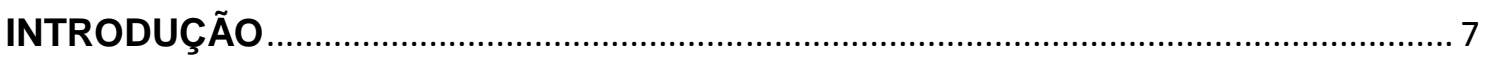

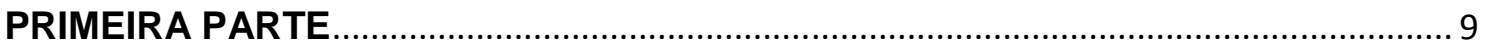

Capítulo 1 - A Intervenção Do Estado No Domínio Econômico................................ 9

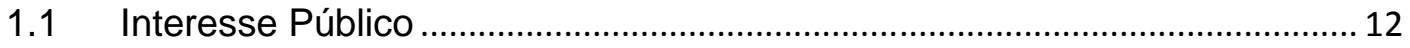

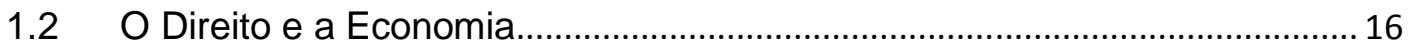

1.3 Modalidades de Intervenção do Estado no Domínio Econômico ................... 19

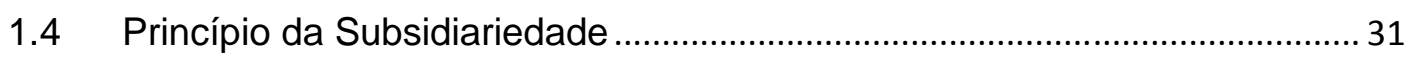

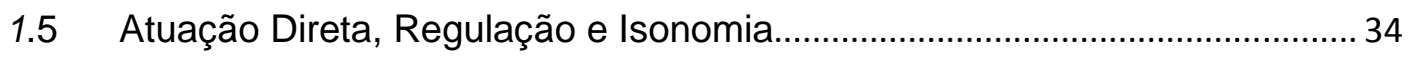

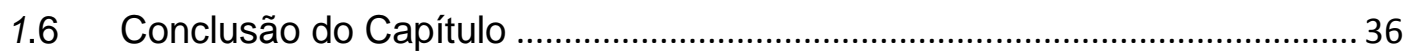

Capítulo 2 - Os Contratos Administrativos e o Regime Público: Das Cláusulas

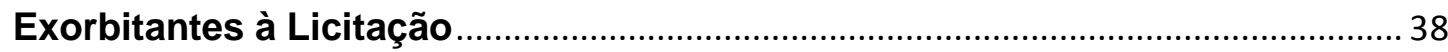

2.1 A classificação dos contratos da Administração Pública ................................ 39

2.2 Características diferenciais dos contratos administrativos ........................... 41

2.2.1 Características específicas típicas de contratos em geral ............. 41

2.2.2 Cláusulas Exorbitantes......................................................................... 44

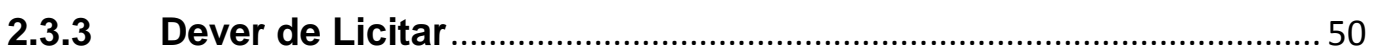

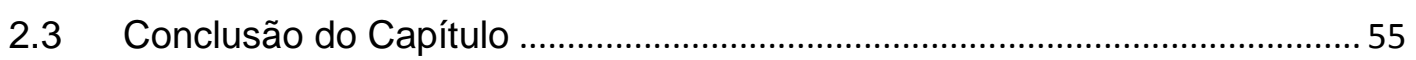

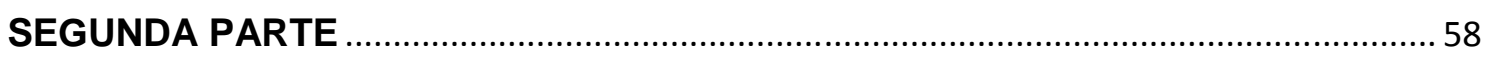

Capítulo 3 - As Sociedades de Economia Mista .................................................... 58

3.1 O Regime das Sociedades de Economia Mista ...............................................59

3.2 Cláusulas Exorbitantes e Obrigatoriedade de Licitação nas Sociedades de

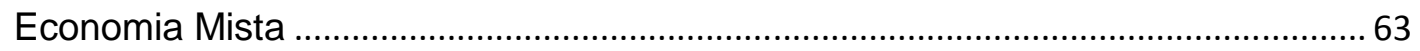

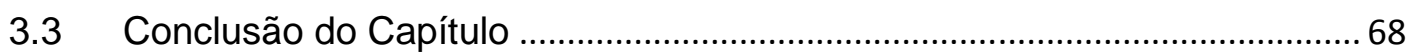

Capítulo 4 - O Caso da Petrobrás: Peculiaridades e o Procedimento Licitatório

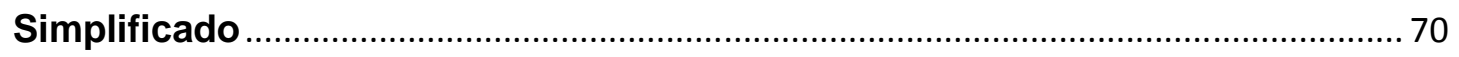

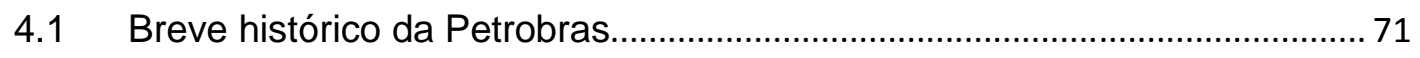

4.2 O Atual Regime da Petrobras ....................................................................... 75

4.3.1 O Regime Licitatório Simplificado da Petrobras................................. 78

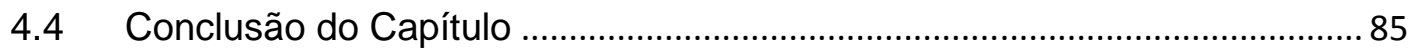

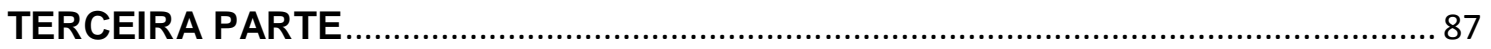

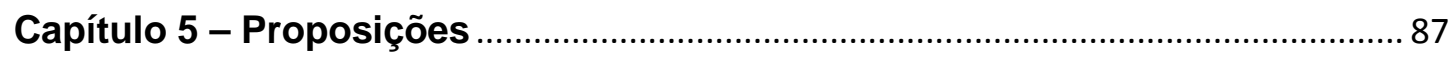


5.1 A Superação da Dicotomia Inflexível dos Regimes Público e Privado ......... 87

5.2 A Aplicação da Análise Econômica do Direito à Atuação da Petrobras ...... 93

5.3 A Petrobras Como Sociedade de Economia Mista e Instrumentalização de

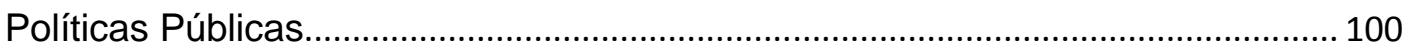

CONCLUSÃO

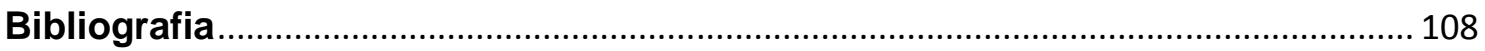




\section{RESUMO}

Esta monografia tem como objeto de análise os meios através dos quais o Estado intervém na economia e, notadamente, como o faz através da Petrobras e seus contratos. Para tanto é desejável se compreender exatamente as possíveis modalidades de intervenção estatal, norteadas pela evolução do modelo de Estado e pela noção de interesse público. O prosseguimento do estudo passa pelo o esforço de diferenciação prática analítica entre os regimes público e privado quando da celebração de contratos. Em seguida e com base nesses conceitos, busca-se, através do exame do regime híbrido das sociedades de economia mista, sistematizar a problemática advinda das diferenças entre os regimes contratuais. Então, após a contextualização indispensável ao debate, será possível se analisar especificamente o caso da Petrobras. Nessa análise se busca demonstrar as especificidades advindas de um tratamento normativo diferenciado e da importância da estatal no cenário nacional. Ao final, e essa é a conclusão alcançada, percebe-se que é possível otimizar em muito a atuação da empresa de modo a garantir a sua eficiência na tutela dos direitos humanos, sendo a diferenciação rígida e apriorística entre os regimes incompatível com o atual estágio jurídico em que vivemos, bem como a sua instrumentalização sistemática para concretização de políticas públicas. Isso só é possível, entretanto, após um exame profundo, para além do positivismo, acerca do contexto histórico, social e econômico em que nos encontramos.

\section{PALAVRAS-CHAVE}

Intervenção do Estado na Economia - Interesse Público - Princípio da Subsidiariedade - Contrato Administrativo - Regimes Contratuais - Lei $\mathrm{n}^{\circ}$ 8.666/93 - Licitação - Cláusulas Exorbitantes - Sociedades de Economia Mista - Petrobras - Contratos da Petrobras - Análise Econômica do Direito. 


\section{INTRODUÇÃO}

A presente exposição, destinada a sistematizar e criticamente analisar o regime jurídico aplicável à Petrobras e, sobretudo, aos seus contratos, é dividida em três partes. O propósito da primeira parte é o de, inicialmente, delinear brevemente os meios pelos quais o Estado intervém na economia, relacionandoos com o interesse público e destacando-se a atuação direta estatal, tanto no que diz respeito à exploração econômica feita pelo Estado em regime de competição quanto à exploração em regime de monopólio, ambas permeadas pelo princípio da subsidiariedade.

Em seguida, busca-se contextualizar o universo dos contratos administrativos para que seja possível compreender as repercussões típicas do regime contratual público, quando posto em comparação com os contratos privados. Espera-se demonstrar as distinções clássicas entre os regimes a fim de justificar eventuais peculiaridades de cada um deles.

A segunda parte, por sua vez, destina-se, inicialmente, à compreensão do regime jurídico aplicável às sociedades de economia mista em geral, levando em conta a sua natureza híbrida, resultado de uma fusão entre o regime privado e o regime público. Nesse ponto, se destacarão as distinções entre cada um dos regimes contratuais vistos na primeira parte no que diz respeito às suas repercussões práticas. Passa-se, finalmente, à análise específica do caso da Petrobrás e seus contratos, que, a despeito de possuirem as muitas das mesmas polêmicas teóricas concernentes às outras sociedades de economia mista, apresentam controvérsias próprias, sobretudo em função da sua importância para a economia e desenvolvimento nacional e da edição de normas contratuais próprias.

Como se sabe, há relevante debate doutrinário e prático acerca da constitucionalidade da disciplina normativa destinada exclusivamente à Petrobras (Decreto $n^{\circ} 2745$ ) e seu regime em geral, bem como acerca da natureza de seus 
contratos. Para compreendê-lo e, ao menos tentar solucioná-lo de forma adequada, é necessário aplicar todo o arcabouço teórico disposto nos tópicos descritos acima. É para esse esforço que se reserva a terceira parte da exposição, a tentativa de aplicação dos preceitos discorridos ao caso concreto da Petrobras e seu regime para uma conclusão ad legis ferenda que possa contribuir com o debate futuramente, no sentido de que se crie uma flexibilização na distinção entre os regimes público e privado, na esteira do princípio da juridicidade e que se repense os limites da instrumentalização da empresa para fins governamentais. 


\section{PRIMEIRA PARTE}

\section{Capítulo 1 - A Intervenção Do Estado No Domínio Econômico}

Uma das grandes questões das ciências humanas contemporâneas notadamente do direito, da política e da economia - reside na aferição da extensão e dos moldes que idealmente deveria ter a relação entre o Estado e a economia e, consequentemente, de como ela deveria afetar a vida dos cidadãos ${ }^{1}$. A consolidação do modelo capitalista nos Estados ocidentais e, posteriormente, a crise do modelo liberal-burguês elevou a discussão à posição central que hoje ostenta dentro do debate acadêmico e político ${ }^{2}$.

A relação entre o Estado - ainda durante a sua fase precária - e a economia data desde o desenvolvimento do feudalismo, passando pelo Estado absolutista, pelo Estado liberal e chegando hoje ao Estado democrático de direito. Pode-se dizer que o Estado moderno teve seu início sob a forma do absolutismo ${ }^{3}$, onde a soberania e o paternalismo eram predominantes. No que diz respeito à relação Estado/economia, que teve sua importância destacada primeiramente no seio do Estado liberal, onde houve um movimento de reação ao regime absolutista que antes imperava, a tarefa das instituições estatais era, inicialmente, apenas garantir a liberdade para que o mercado pudesse se desenvolver e se

\footnotetext{
${ }^{1}$ De Adam Smith até Lênin, de Hobbes até Rousseau, a enorme maioria dos grandes cientistas sociais se dedicaram a investigar o tema da interação Sociedade - quase sempre sob a forma de Estado - e indivíduo. As repercussões do debate são o cerne do convívio social. A extensão e os moldes da relação entre os cidadãos e sua interação com o Estado é a origem de todos os aspectos das ciências humanas.

${ }^{2}$ Em que pese a queda do muro de Berlin, o fim da Guerra Fria, a queda da União Soviética e a flexibilização do comunismo, ainda existe uma dicotomia indiscutível entre liberais e conservadores. É bem verdade que os extremos da atual contenda não são tão antitéticos quanto eram anteriormente e a divisão não se dá de forma tão maniqueísta quanto anteriormente se dava, no entanto, como se pode observar, por exemplo, nos Estados Unidos, o embate entre Democratas e Republicanos diz respeito exatamente ao papel do Estado em relação aos indivíduos e afeta os mais triviais aspectos da vida dos cidadãos americanos, como onde eles fazem suas compras ou até onde eles decidem morar. Confira-se, exemplificativamente, pesquisa que demonstra essa crescente polarização na política americana. A pesquisa se encontra disponível em: http://www.people-press.org/2014/06/12/political-polarization-inthe-american-publicl, consultada em: 17/10/2014.

${ }^{3}$ DALLARI, Dalmo de Abreu. Elementos da Teoria Geral do Estado, 23 ed. São Paulo: Saraiva, 2002. p. 275.
} 
expandir como seria próprio de sua natureza ${ }^{4}$. Fundado nos ideais de racionalidade e individualismo, era o chamado Estado mínimo, ou Estado do laissez faire que seguia a crença de que a "mão invisível do mercado" seria método mais eficiente de correção de qualquer adversidade ${ }^{5}$.

A crise do Estado mínimo, comumente associada com as consequências sociais negativas oriundas de falhas mercadológicas ensejadas pela lógica individualista típica do capitalismo liberal, notadamente após a revolução industrial, com o acúmulo de riquezas, com o surgimento do comunismo como modelo econômico/social concorrente e, finalmente, com as sequelas deixadas pela primeira guerra mundial ${ }^{6}$, alterou drasticamente o desempenho do ente estatal perante a atividade privada. O Estado passou a ter também a função de prevenir eventuais falhas sistêmicas que poderiam surgir do livre mercado e nele intervir, buscando seu desenvolvimento, tendo em vista fins de cunho social destacando-se aqui, geralmente, a distribuição de riquezas -, de acordo com a ideologia econômica e política específica de cada população, era o chamado Estado interventor, ou Estado social ${ }^{7}$, cujo marco inicial está comumente

\footnotetext{
4 "Sob o ângulo da atividade econômica privada os principais fundamentos do Estado liberal-burguês eram a propriedade, pela qual se assegurava a titularidade, o gozo e a fruição dos bens, os contratos, veículos de circulação destes bens. Sobre ambos à Administração Pública não competia impor qualquer restrição, salvo se necessária para que os direitos de outros cidadãos não fossem prejudicados. Acreditava-se que o mercado seria muito mais benéfico para o conjunto da sociedade se agisse livremente, não devendo ser funcionalizado por qualquer finalidade coletiva" ARAGÃO, Alexandre Santos de. Agências Reguladoras e a Evolução do Direito Administrativo Econômico, $3^{\text {a }}$ ed. Rio de Janeiro: Forense, 2013, p. 53. No mesmo sentido ver GRAU, Eros Roberto. A Ordem Econômica na Constituição de 1988. $5^{\mathrm{a}}$ ed. Malheiros: São Paulo, 2000. p. 14.

“"Já no inicio do século XVIII o poder público era visto como inimigo da liberdade individual, e qualquer restrição ao individual em favor do coletivo era tida como ilegítima. Essa foi a raiz individualista do Estado liberal (...). Quanto às relações econômicas, a obra célebre de Adam Smith, 'A riqueza das Nações', publicada em 1776, correspondia perfeitamente aos desejos dos grandes proprietários e comerciantes, sustentando que cada homem é o melhor juiz de seus interesses e deve ter a liberdade de promovê-los segundo a sua livre vontade. Afirmando a existência de uma ordem natural, capaz de assegurar a harmonia espontânea de todos os interesses" DALLARI, Dalmo de Abreu. op. cit. p. 275.

${ }^{6}$ ARAGÃO, Alexandre Santos de. op. cit. p. 58. O autor destaca, além disso, o sufrágio universal que conferiu ao Estado pós-liberal, uma natureza multiclasse, fazendo com que fosse possível a criação de um objetivo metaindividual do Estado como um todo, superando a noção de que sua única atribuição seria permitir que seus cidadãos pudessem perseguir seus fins individuais.

${ }^{7}$ Relevante, quanto ao ponto, a ressalva de ARAGÃO. Para o autor definir o Estado pós-liberal como intervencionista, do bem-estar social, pós-capitalista, pós-industrial, dirigente ou regulador seria uma simplificação demasiada dos contornos que adquiriu o Estado democrático de direito. Segundo o autor "todas essas denominações estão ao mesmo tempo certas e erradas (...)", uma vez que o Estado Democrático poderia "assumir diversas configurações, pode ter efetivamente se caracterizado em determinado iter histórico como intervencionista, liberal-social, social, etc. Todavia, nenhum destes submodelos pode ser tido como conatural ao Estado Democrático de Direito, já que a sua estrutura básica,
} 
associado à política do New Deal, nos Estados Unidos, política que se deu em reação à crise da bolsa de Nova York em 1929.

O Estado social assumia uma quantidade considerável de obrigações perante os cidadãos, obrigações essas que era incapaz de cumprir adequadamente. Assim, o movimento pendular de evolução de modelo estatal nos trouxe ao atual momento. Trata-se de um Estado cuja lógica é de atuação subsidiária, ou seja, dá-se espaço para os indivíduos, sem deixar de reconhecer que, em determinadas situações, será necessário que o ente estatal trace diretivas, no sentido de prevenir eventuais falhas, inerentes à liberdade mercadológica.

Exatamente por conta dessa nova conjectura política, passou a ser indispensável à ciência econômica e ao direito compreender os contornos da atuação estatal, de modo a ajustá-la à ideologia dominante, tornando a relação economia/Estado a mais harmoniosa possível. Na experiência nacional, em um primeiro momento iniciado por Getúlio Vargas e com auge no período ditatorial, houve uma publicização da vida social, onde o Estado interventor preponderava. Atualmente, após a redemocratização e os movimentos de reabertura da economia nacional, nos encontramos em um Estado constitucional de viés regulador, onde se procura um meio termo no movimento pendular que nos levou do liberalismo para o intervencionismo.

O propósito deste capitulo é analisar os meios pelos quais o Estado pode intervir no domínio econômico - no mercado - em abstrato e, mais especificamente no ordenamento brasileiro, e quais são as implicações de cada uma dessas modalidades de intervenção. Em outras palavras, analisaremos os meios pelos quais o Estado - sobretudo o brasileiro - procura agir para preservar e promover os princípios de sua ordem econômica ${ }^{8}$, que é, em última instância, o que justifica qualquer intervenção estatal na economia. Faz-se indispensável,

tal como, inclusive definido pelo art. $1^{\circ}$ da nossa Constituição Federal, deixa as portas abertas para outras sobconcepções políticas que possam se desenvolver em seu marco" ARAGÃO, Alexandre Santos de. op. cit. p. 59.

${ }^{8}$ BARROSO, Luís Roberto. A Ordem Econômica Constitucional e os Limites à Atuação Estatal no Controle de Preços, in Revista de Direito da Associação de Procuradores do Novo Estado do Rio de Janeiro:Direito da Regulação, v. XI, coord. Alexandre dos Santos de Aragão, Rio de Janeiro: Lumen Iuris, 2002, p. 60. 
entretanto, antes de qualquer análise, uma breve introdução sobre o que é o interesse público e quais são as particularidades do esforço de sua efetivação.

\subsection{Interesse Público}

Antes de adentrar especificamente no tema pertinente à intervenção do Estado no domínio econômico, é imprescindível o estudo do principal norte de qualquer atuação estatal, que irá permear o presente estudo em todo seu conteúdo. A tutela do interesse público é o fator que dá à pessoa jurídica que é o Estado sua natureza diferenciada. Porém, como defini-lo? Trata-se, na verdade, do principal dilema que abrange o Direito Público em sua integralidade ${ }^{9}$, afinal, como veremos, todo ato público deve, sob pena de nulidade, observá-lo. A corrente dominante no Direito Administrativo clássico conceitua o interesse público como "a dimensão pública dos interesses individuais, ou seja, dos interesses de cada indivíduo enquanto parte típice da Sociedade (entificada juridicamente no Estado)" $"$.

Essa concepção de interesse público - similar ao conceito de bem comum -, dá origem ao chamado princípio da supremacia do interesse público sobre o particular, que significa basicamente o que a sua denominação sugere. Seu conceito baseia-se na noção de que sendo o interesse público a soma dos interesses privados, a parte que constitui o todo jamais poderia a ele se sobrepor. Aqui, porém, se faz uma importante ressalva. Com efeito, o princípio da supremacia do interesse público, defendido na doutrina administrativista tradicional desde a sua construção ${ }^{11}$ e responsável pela concepção segundo a qual a Administração Pública invariavelmente ostenta posição preponderante sobre o particular, tem recebido duras críticas, e, a despeito de ainda ser frequentemente

\footnotetext{
9 "La pregunta [como definir o estado?], aparentemente sencilla, ha sido, sin embargo, el centro de lós debates que han hecho posible la elaboración dogmática del Derecho Administrativo". DE ENTERRÍA, Eduardo Garcia e FERNÁNDEZ, Tomás-Ramon. Curso de Derecho Administrativo I, 5a ed. Madri: Civitas, 1998, p. 23. E, na doutrina brasileira: GRAU, Eros Roberto. O Direito Posto e o Direito Pressuposto. São Paulo, Malheiros, 2005. p. 25.

${ }^{10}$ MELLO, Celso Antônio Bandeira de. Curso de Direito Administrativo, 30 a ed. São Paulo: Malheiros, 2013. p.60-61. No mesmo sentido, definindo o interesse público como "bem-estar coletivo", DI PIETRO, Maria Sylvia Zanella. Direito Administrativo, 14ª ed. São Paulo: Atlas, 2012. p 69.

${ }^{11}$ MELLO, DI PIETRO, MEIRELLES e CARVALHO FILHO são alguns dos muitos doutrinadores clássicos defensores do princípio.
} 
mencionado na grande maioria dos manuais de direito administrativo e constitucional, deve ser repensado ${ }^{12}$.

De fato, soa estranha a existência de um princípio cujo único propósito é definir aprioristicamente o que deve preponderar independentemente do caso concreto. O desenvolvimento do neoconstitucionalismo e a consolidação da máxima tutela dos direitos fundamentais como núcleo essencial do Estado democrático de direito impossibilita tal concepção. Vale dizer: os princípios constitucionais e as normas binárias se diferenciam, sobretudo pela gradação da aplicação dos primeiros de acordo com a conjectura casuística, contrariamente ao que ocorre com as normas, onde ou bem há a aplicação de seu conteúdo em sua totalidade, ou simplesmente não há a aplicação da norma em absoluto ${ }^{13}$. Desse modo, aplicar um princípio "hierarquicamente superior", impassível de mitigação, configuraria nada menos que uma transgressão aos valores constitucionais que objetivam a máxima efetividade (otimização) dos princípios responsáveis pela promoção dos direitos fundamentais através da ponderação ${ }^{14}$.

O próprio conceito prático de interesse público, como se expôs, envolve complexidade de tamanho grau que impossibilita a compreensão aplicada do princípio de sua supremacia. Muito embora haja esforços no sentido de classificar o interesse público como bem comum, "a ideia da existência de um interesse público inconfundível com os interesses pessoais dos integrantes de

\footnotetext{
${ }^{12}$ Sustenta-se, inclusive, que essa concepção, fruto da corrente utilitarista seria o que ensejou regimes autoritários e liberticidas. V. BINENBOJM, Gustavo. Uma Teoria de Direito Administrativo. $3^{\text {a }}$ ed. Rio de Janeiro: Renovar, 2014. p. 85. De fato, não se pode conceber o administrado com um sujeito meramente passivo da atividade administrativa. Para ENTERRÍA e FERNÁNDEZ "Este término "administrado" es, realmente, poco feliz; como participio pasivo del verbo administrar, parece argüir uma posición simplesmente pasiva de um sujeto que vendría a sufrir o soportar La acción administrar que sobre él ejerce outro sujeto eminente y activo (...). El absolutismo sí concebía em esse sentido pasivo la posición del individuo dentro de la comunidad política, titular de meras cargas, obligaciones y deberes que le imponía um poder público transcendente a todos y cada uno de los individuos y aun al conjunto de todos ellos (...)" DE ENTERRÍA, Eduardo Garcia e FERNÁNDEZ, Tomás-Ramon. Curso de Derecho Administrativo II, $5^{\text {a }}$ ed. Madri: Civitas, 1998, p. 17-18.

${ }^{13}$ ALEXY, Robert. Theorie der Grundrechte. 2 ed. Frankfurt am Main: Suhrkamp, 1994, pág. 93.

${ }^{14}$ A ponderação é uma técnica hermenêutica para resolver casos difíceis, onde há um conflito de princípios constitucionais. Se trata de sopesar, com os detalhes do caso concreto, os valores em choque e procurar conferir a eles a máxima efetividade possível, muitas vezes em um regime de mútua cedência, onde se procura sacrificar o mínimo possível de cada um deles. V.BARCELLOS, Ana Paula. Ponderação e Racionalidade. Rio de Janeiro: Renovar, 2005, p. 91 e ss. No mesmo sentido v. DWORKIN, Ronald. Taking Rights Seriously, Cambridge: Harvard University Press, 1977.
} 
uma sociedade política e superior a ele" ${ }^{\text {15 }}$ simplesmente não sobrevive à ductibilidade dos princípios constitucionais advinda dos deveres de integridade e unidade da Constituição sem, no entanto, comprometer seu pluralismo material ${ }^{16}$.

É desafio virtualmente insuperável a criação de um conceito preciso para o interesse público que prescinda das peculiaridades do caso concreto. Ao menos até a presente data, nunca houve uma definição universalmente aceita capaz de diferenciar em abstrato a "justa medida da cedência recíproca que deve existir entre interesses individuais e interesses coletivos em um Estado democrático de direito" $" 17$. O tema é de enorme complexidade e não é o escopo central da presente exposição ${ }^{18}$. É essencial, entretanto, a ressalva, de modo a que se conceba os institutos que serão expostos à luz dos princípios constitucionais a eles aplicáveis, em particular a razoabilidade que vai auxiliar o esforço de ponderação no caso a caso ${ }^{19}$. A posição preponderante da Administração Pública é, de fato, a regra ${ }^{20}$, entretanto, como se vem de expor, não há princípio absoluto, sendo imprescindível a análise do caso concreto permeado pelo princípio da razoabilidade a fim de se otimizar a tutela aos direitos fundamentais.

Outro princípio diretamente ligado ao interesse público é a sua indisponibilidade. Por não serem os titulares dos interesses ou bens públicos,

\footnotetext{
${ }^{15}$ BINENBNOJM, Gustavo. op. cit. p. 31.

16 "La coexistencia de valores y principios, sobre la que hoy debe basarse necesariamente una Constitución para no renunciar a sus cometidos de unidad y integración y al mismo tiempo no hacerse incompatible con su base material pluralista, exige que cada uno de tales valores y principios se asuma con carácter no absoluto, compatible con aquellos otros con los que debe convivir". ZAGREBELSKY, Gustavo. El derecho dúctil. Ley, Derechos, Justicia (trad. Mariana Gascón). Madrid: Editorial Trotta, 2011. p. 14.

${ }^{17}$ BINENBNOJM, Gustavo. op.cit. p. 30.

${ }^{18}$ Para uma profunda análise do tema v. BINENBNOJM, Gustavo. idem. p. 83 e ss. No mesmo sentido, v. ÁVILA, Humberto Bergmann. Repensando o "Princípio da supremacia do interesse público sobre o particular", in Interesses Públicos versus Interesses Privados: Desconstruindo o Princípio de Supremacia do Interesse Público org. Daniel Sarmento, Rio de Janeiro: Lumen Iuris. p 171-216. 2005. OSÓRIO, Fábio Medina. Existe uma supremacia do Interesse Público sobre o privado no direito Administrativo brasileiro? Revista de Direito Administrativo, Rio de Janeiro. v. 220, p. 69-107, 2000, SARMENTO, Daniel. Interesses públicos "versus" interesses privados na Perspectiva da Teoria e da Filosofia Constitucional in Interesses Públicos versus Interesses Privados: Desconstruindo o Princípio de Supremacia do Interesse Público org. Daniel Sarmento, Rio de Janeiro: Lumen Iuris. p. 23-116, 2005. e BARROSO, Luís Roberto. Curso de Direito Constitucional Contemporâneo. $4^{\mathrm{a}}$ ed. Rio de Janeiro: Saraiva, 2013. p. 91 e ss.

${ }^{19}$ Pra uma completa lição sobre o princípio da razoabilidade v. BARROSO, Luís Roberto. Curso de Direito Constitucional Contemporâneo. op. cit. p. 328

${ }^{20}$ Idem. p. 91-92.
} 
nem a Administração Pública nem seus agentes possuem a prerrogativa de deles dispor. Ocorre, no entanto, que nem todo interesse tutelado pela Administração é público, no seu sentido estrito.

Comumente confunde-se o interesse público propriamente dito - interesse público primário -, com o interesse da Administração Pública - interesse público secundário $^{21}$. O primeiro remonta, de fato, ao interesse da coletividade, fim próprio do Estado, o que justifica em essência a sua consolidação como corpo político e social. Seu objetivo fim é a promoção da tutela dos direitos fundamentais e, sobretudo, do princípio da dignidade da pessoa humana. O segundo, por sua vez, diz respeito aos interesses instrumentais do Poder Público. São os interesses acessórios através dos quais a Administração Pública conseguirá obter mais lucro para o erário ou realizar metas orçamentárias, por exemplo. Sustenta-se que os interesses públicos secundários sequer têm natureza pública, eis que configurariam a atuação privada do Poder Público, que buscaria aumentar as vantagens para si próprio ${ }^{22}$.

É instintiva a conclusão de que o princípio da indisponibilidade apenas se aplica ao interesse público primário. Muitas vezes, a própria satisfação do interesse primário recomendará que o Poder Público efetue mais gastos ou abra mão de determinadas pretensões patrimoniais. Essa distinção é essencial para a compreensão da atuação do Estado em sua generalidade. Qualquer ato estatal deve ser pautado pelo interesse público, afinal, como se viu, é precisamente o fator que legitima a sua existência.

\footnotetext{
${ }^{21}$ A classificação é originária de ALESSI, Renato. Principi di diritto amministrativo, v. I. Milão: A. Giuffrè, 1974. p. 226-227: "Questi interessi pubblici, collettive, dei quali l'amministrazione deve curare il soddisfacimento, non sono, si noti bene, semplicemente l'interesse dell'Amministrazione intesa come apparato organizzativo autonomo, sibbene quello che è stato chiamato l'interesse collettivo primario, formato dal complesso degli interessi individuali prevalenti in una determinata organizzazione giuridica della collettività, mentre l'interesse dell'aparato, se può esser concepito un interesse dell'aparato unitariamente considerato, sarebbe semplicemente uno degli interessi secondari che si fanno sentire in seno alla collettività, e che possono essere realizzati soltanto in caso di coincidenza, e nei limiti di sifatta coincidenza, con l'interesse collettivo primario". Sua aplicação ao direito brasileiro é pacífica. V., por todos, MELLO, Celso Antônio Bandeira de, op. cit. p. 59 e JUSTEN FILHO, Marçal. Curso de Direito Administrativo, $8^{\mathrm{a}}$ ed. Belo Horizonte: Editora Fórum, 2012. p. 120.

22 JUSTEN FILHO, Marçal. op. cit. p. 120. No mesmo sentido, MELLO, Celso Antônio Bandeira de. op.cit. p. 66-67 e BARROSO, Luís Roberto. Curso de Direito Constitucional Contemporâneo. op. cit. p. 92 e 93.
} 
Convém registrar, ainda, que ao princípio da indisponibilidade se aplica a mesma lógica do princípio da supremacia. Não existem princípios aprioristicamente absolutos, sendo necessária uma ponderação de acordo com o caso concreto, sob o prisma da razoabilidade, para se aferir qual medida tomar em cada hipótese e em qual proporção o interesse é, de fato, indisponível.

Feito o breve desvio, convém retornarmos ao estudo da intervenção do Estado especificamente no que diz respeito ao domínio econômico. O primeiro passo para essa análise é a tentativa de compreender o Direito sob o ponto de vista econômico e a economia sob o enfoque jurídico, apenas assim é possível aproximar o estudo da intervenção estatal de suas repercussões, uma vez que não se pode conceber o instituto sem a adequada compreensão da relação entre direito e economia, fatores nodais da atuação pública.

\subsection{O Direito e a Economia}

Retomando o que foi dito anteriormente, o Estado absolutista inaugurou a evolução do que se tornaria o modelo atual de Estado democrático de direito, que comporta diversos submodelos, alguns que demonstram maior atuação estatal na economia (estado social dirigente, por exemplo, como é o caso dos países escandinavos) e outros que apontam para uma maior liberdade do mercado (estado neoliberal, como é o caso dos Estados Unidos e da Inglaterra). Desde então, e muito em função da existência desses diversos submodelos, a forma como o Estado - transvestido atualmente, de forma mais visível, de regulações -, interage com a economia passou a receber exponencialmente mais atenção ${ }^{23}$. Por fins metodológicos, para se estudar adequadamente o fenômeno, é desejável, antes de tudo, que se compreenda cada um dos "sujeitos" dessa relação e seus pontos convergentes e conflitantes.

\footnotetext{
${ }^{23}$ Há na doutrina estrangeira, sobretudo na francesa, esforços no sentido de desenvolver um setor específico que estudaria o direito público da economia. "Le droit public de l'economie est ainsi le droit applicable aux interventions des personnes publiques dans l'économie et aux organes de ces interventions, ou encore, pour faire court, le droit de l'intervention publique en marière économique" DEVOLVÉ, Pierre. Droit Public de l'Economie. Paris: Précis, 1998. p. 16. Se assemelha a algumas questões trazidas pelo Direito Econômico ensinado por MONCADA (MONCADA, Luís Cabral de Oliveira. Direito Económico, 4a ed. Coimbra: Coimbra Editora, 2003) e por GRAU (GRAU, Eros Roberto. A Ordem Econômica na Constituição de 1988. op. cit.).
} 
A economia está longe de ser o único fator a afetar a atuação estatal ${ }^{24}$, porém, em qualquer democracia, sua influência determinante é indiscutível ${ }^{25}$. A realização do interesse público e a persecução dos direitos fundamentais exigem recursos, cuja obtenção está diretamente ligada a fatores econômicos ${ }^{26}$ e, sendo aqueles, como se viu, os principais objetivos do Estado democrático de Direito e, consequentemente, da Administração Pública ${ }^{27}$, não seria absurdo afirmar que a economia é, no mínimo, um dos fatores preponderantes para a atuação normativa do Estado $^{28}$ e para o Direito como um todo.

Discute-se intensamente a relação entre a atividade normativa do Estado, vista como o direito em geral, e a economia. Chega-se a dizer que o direito, não existe como ciência autônoma, sendo tão somente uma ferramenta da economia. Tal corrente, liderada por POSNER $^{29}$, derivada da corrente jusfilosófica do pragmatismo utilitarista e oriunda da escola liberal da Universidade de Chicago, vislumbra que o direito tem o papel único de dar à determinada situação a solução economicamente mais vantajosa, sendo essa, via de regra, aquela que prestigia em maior escala as liberdades individuais, ostentando, com isso, o menor custo de transação. No outro extremo ideológico, os seguidores de MARX, ao menos aqueles que aderem à interpretação mais difundida ${ }^{30}$,

\footnotetext{
${ }^{24}$ A religião e a moral, por exemplo, muitas vezes afetam e direcionam a conduta do Estado com a mesma ou maior intensidade que fatores de cunho econômico.

25 "Não podemos ter a ingenuidade de achar que o Direito tem inteira disponibilidade sobre o mercado. Malgrado as suas inegáveis possibilidades de ingerência, os aspectos de maior dinamismo do mercado são dificilmente apreensíveis pelo Direito" ARAGÃO, Alexandre Santos de. op. cit. p. 23.

${ }^{26}$ Colocando de forma simples e óbvia: "Individual rights and freedoms depend fundamentally on vigorous state action". SUNSTEIN, Cass e HOLMES, Stephen. The costs of Rights: Why liberty depends on taxes, New York: W. W. Norton \& Co., 1999, p. 255.

${ }^{27}$ Sobre a atendimento ao interesse público como objetivo do Estado: MELLO, Celso Antônio Bandeira de. op. cit. p. 29. Sobre a centralidade dos direitos fundamentais no Estado pós -liberal: BARROSO, Luís Roberto. Curso de Direito Constitucional Contemporâneo. op. cit. p. 300.

${ }^{28}$ A despeito de preponderante, não é possível se conceber economia, ou direito sem o Estado. Nesse sentido. V. "Lo primero de lo que queremos dejar constancia es que, a pesar de los pesares (...), el Estado resulta absolutamente necesario para el mantenimiento de cualquier sociedad mínimamente civilizada y, desde luego, de las sociedades avanzadas contemporâneas". ORTIZ, Gaspar Ariño. Princípios de Derecho Público Económico, Granada: Comares. 1999. p. 25.

${ }_{29}$ V. POSNER, Richard. The Constitution as an Economic Document, in George Washington Law Review, ${ }^{\circ} 56,1987$.

${ }^{30}$ GRAU demonstra discordar que essa interpretação seja a correta. Para ele: "uma das posturas que se poderia adotar a esse respeito - mas não se deve adotar (...) - parte da suposição, equivocada, de que o direito corresponde a um mero reflexo da economia. Essa suposição decorre de uma leitura equivocada de Marx" GRAU, Eros Roberto. O Direito Posto e o Direito Pressuposto. op. cit. p. 45.
} 
compreendem o Direito como "uma superestrutura, de caráter ideológico, condicionada pela infraestrutura econômica ${ }^{31,}$.

Não concordamos com as opiniões expostas acima e tampouco é o escopo do presente estudo analisar os pormenores filosóficos da relação Direito/economia. Diferentemente do que sustentam os defensores do pragmatismo ou do materialismo histórico de MARX, enxergamos como mais razoável defender a teoria de que o Direito não pode ser enxergado exclusivamente como um produto ou instrumento da economia ${ }^{32}$. Muito pelo contrário, como já dito, há uma relação indiscutível de intercâmbio permanente entre os dois campos, tendo ambos capacidade de mútua e significativa influência, notadamente no seio do Estado Democrático de Direito. Saliente-se, por oportuno, que, curiosamente, a despeito de ostentarem polos diametralmente opostos no que diz respeito à ideologia econômico-política, ambas as correntes demonstram ter uma visão muito similar sobre o que seria o direito perante a economia.

O que resta claro, se seguido o raciocínio aqui defendido, é a dialeticidade da coexistência entre ambos, onde um influencia e limita o outro, tomando para si, inclusive, institutos que antes pertenciam exclusivamente ao outro ramo ${ }^{33}$. Tome-se como exemplo dessa apropriação, por um lado, a correção monetária, instituto eminentemente econômico do qual faz uso o direito para, na prática,

\footnotetext{
${ }^{31}$ REALE, Miguel. Lições Preliminares de Direito. 25 ed. São Paulo: Saraiva. 2000. p. 21.

${ }^{32}$ SUNSTEIN leciona que não se pode conceber o mercado autonomamente ao Direito, é da sua natureza depender do Direito e das leis. "Market depends on law, but this is not an argument against market" SUNSTEIN, Cass. The Partial Constitution. Cambridge: Harvard University Press, 1993. p. 59. No mesmo sentido DEVOLVÉ, Pierre. op. cit. p. 101 e ss. Na doutrina nacional, compartilham dessa opinião, entre outros ARAGÃO (v. ARAGÃO, Alexandre Santos de. op. cit. p. 22 e ss), REALE (REALE, Miguel. op. cit. p. 20 e ss), GRAU (GRAU, Eros Roberto. A Ordem Econômica na Constituição de 1988. op. cit. p. 13 e ss).

33 "Diríamos que o Direito é como o rei Midas. Se na lenda grega esse monarca convertia em ouro tudo aquilo em que tocava, aniquilando-se na sua própria riqueza, o Direito, não por castigo, mas por destinação ética, converte em jurídico tudo aquilo em que toca, para dar-lhe condições de realizabilidade garantida, em harmonia com os demais valores sociais”. REALE, Miguel. op. cit. p. 22. Da mesma forma, entendemos que a economia tem a capacidade de tomar determinado instituto jurídico para si e torná-lo em um fator econômico.
} 
garantir a proporcionalidade real de uma restituição ${ }^{34}$. Por outro, tome-se a segurança jurídica; um princípio tipicamente jurídico que passou a ser valorado quando da celebração de negócios privados e até na tomada de decisão em políticas públicas macroeconômicas ${ }^{35}$.

O que interessa, porém, para o presente estudo, é a atuação ${ }^{36}$ do Estado sobre a economia, levando em conta, por óbvio, o papel do Direito nessa relação. Essa atuação pode se dar de diversas formas, o tópico que segue é dedicado justamente à exposição e exame das modalidades através das quais o Estado pode intervir no domínio econômico.

\subsection{Modalidades de Intervenção do Estado no Domínio Econômico}

Inicialmente, é bem de ver que no Estado democrático de Direito a ordem econômica tem como principais atores os particulares ${ }^{37}$. Sem embargo a essa constatação, a função do Estado é imprescindível para o funcionamento mercadológico, uma vez que o regime do laissez faire se provou superado ante a crise do Estado liberal, como já referido.

As diferenças culturais, sociais, políticas e ideológicas tornam o exercício de encontrar um lugar comum para todos os submodelos pós-modernos, no que diz respeito ao grau de intervenção que determinado Estado exerce na sua economia, virtualmente impossível. No entanto, ainda que com diferenças impulsionadas por essa diversidade, é possível identificar mecanismos comuns a todos, através dos quais cada um deles, em maior ou menor escala, age sobre o domínio econômico.

\footnotetext{
${ }^{34}$ A correção monetária judicial foi positivada na Lei $n^{\circ} 6.899 / 81$, em seu art. $1^{\text {o: }}$ "A correção monetária incide sobre qualquer débito resultante de decisão judicial, inclusive sobre custas e honorários advocatícios (...)".

35 "The stability of the constitutional framework has economic value; by reducing uncertainty it facilitates investment”. POSNER, Richard. op. cit. p. 33.

${ }^{36}$ GRAU atenta para a diferença entre as nomenclaturas atuação e intervenção do Estado na economia. De fato, terminologicamente, há uma diferença entre os vocábulos, no entanto, não se fará nenhuma distinção entre os dois termos por fins metodológicos. Cf. GRAUS, Eros. A Ordem Econômica na Constituição de 1988. op. cit. p. 124.

${ }^{37}$ BARROSO, Luís Roberto. A Ordem Econômica Constitucional e os Limites à Atuação Estatal no controle de preços, op. cit. p. 56.
} 
Há alguma divergência doutrinária em relação à terminologia da classificação específica de cada uma dessas modalidades, mas seguindo a classificação de BARROSO ${ }^{38}$, que busca combinar alguma das classificações existentes $^{39}$, são três as modalidades de intervenção estatal: i) o fomento, ii) a disciplina e iii) a atuação direta. As duas primeiras correspondem à intervenção indireta da Administração Pública na economia sob a forma de regulação, enquanto que a terceira é uma intervenção direta ${ }^{40}$, e, ao menos no Estado brasileiro e na grande maioria dos Estados democráticos de Direito, deve se dar apenas em circunstâncias muito específicas ${ }^{41}$.

Qualquer atuação estatal que tenha efeitos diretos sobre a economia se encaixa em uma dessas categorias, e qualquer que seja a modalidade utilizada, por natureza, o objetivo perseguido por essa intervenção necessariamente deve ser a efetivação e tutela do interesse público. Convém uma explicação mais detalhada sobre cada uma delas.

\subsubsection{Fomento}

A atividade de fomento pelo Estado é o mecanismo através do qual a Administração Pública, por meio de uma medida não coercitiva, induz determinado agente econômico a incorporar alguma prática desejável ou a diminuir/encerrar algum comportamento indesejável. A noção de fomento

\footnotetext{
${ }^{38}$ Idem, p. 58.

${ }^{39} \mathrm{O}$ autor busca condensar a ideia central da classificação de outros autores (no caso de Diogo de Figueiredo MOREIRA NETO e Celso Antonio Bandeira de MELLO) e chegar a um ponto comum. Convém ressaltar que, a despeito de usar nomenclaturas distintas, a classificação utilizada por GRAU (GRAU, Eros Roberto. A Ordem Econômica na Constituição de 1988. op. cit. p. 158-159) é materialmente similar à aqui defendida. Para o autor as formas de intervenção estatal podem ser resumidas em; i) intervenção por absorção ou participação (que se assemelhariam à atuação direta), ii) intervenção por direção (equivalente à disciplina) e iii) intervenção por indução (idêntica à atividade de fomento). Desse modo, a interpretação dada por BARROSO parece, de fato, entre as classificações, a mais simplificada e, ao mesmo tempo, abrangente.

${ }^{40}$ MONCADA, Luís Cabral de Oliveira. Direito Económico, 4a ed. Coimbra: Coimbra Editora, 2003.

${ }^{41}$ GRAU faz uma ressalva relevante no que diz respeito à nomenclatura que se utiliza. Para o autor, há diferença significativa entre a intervenção do Estado na economia e a intervenção do Estado sobre a economia. V. GRAU, Eros Roberto. A Ordem Econômica na Constituição de 1988. op. cit. p. 124 e ss.
} 
público, como atividade administrativa autônoma, dissociada do poder de polícia tradicional, surgiu inicialmente na Espanha ${ }^{42}$.

Os incentivos fiscais, os financiamentos e os subsídios são exemplos típicos dos quais o Estado brasileiro faz uso de modo a encorajar determinada conduta que se presuma de interesse público. A lógica se adéqua àquela do direito premial $^{43}$, onde um benefício é garantido ao particular que observe uma conduta que, não fosse por essa promoção por parte do Estado, não valeria a pena e provavelmente não teria sido tomada. São medidas que convidam o agente privado a se comportar de determinada forma, mas que não o obrigam a fazê-lo. Trata-se de um estímulo ao particular pela Administração Pública com fins econômicos ou sociais.

O objetivo desse tipo de intervenção é, como se supõe, uma ponderação de modo a garantir em máxima escala a observância ao interesse público, sem, contudo, limitar significativamente a liberdade de escolha dos particulares através de medidas cogentes ${ }^{44}$. Diferentemente da atividade de disciplina - que será vista mais adiante - a conduta que se quer incentivar, ou, por um lado, não é tão crítica para o interesse público - caso contrário o Estado não poderia se contentar com um mero estímulo -, ou, por outro, se trata de uma atividade que não comporta coerção. Exemplo desse segundo tipo é a criação de novas empresas. É desejável para a economia de qualquer país capitalista a criação de microempresas que ajudem no fluxo de capital, gerando empregos, bens ou serviços. Um Estado democrático de Direito, porém, não pode obrigar um particular a se aventurar em atividades empresárias, mas pode, por exemplo,

\footnotetext{
${ }^{42}$ MENDONÇA, José Vicente Santos de. Uma teoria do Fomento Público: Critérios em Prol de um Fomento Público Democrático, Eficiente e Não-Paternalista, in Revista de Direito da Procuradoria Geral, v. 65, CEJUR:Rio de Janeiro, 2010, p. 120.

${ }^{43}$ BOBBIO, Norberto. Dalla Struttura Alla Funzione. Edizioni di Comunitá: Milão, 1977. p. 33 e ss. Apud GRAUS, Eros Roberto. A Ordem Economica na Constituição de 1988. op. cit. p. 161.

${ }^{44}$ É bem verdade que a corrente economicamente mais liberal associa o simples fato de criar uma situação economicamente mais favorável em si mesmo a uma limitação relevante à liberdade individual dos agentes econômicos, isso porque uma medida desse tipo daria aos concorrentes que não aderirem à barganha, uma desvantagem enorme, fazendo com que seja praticamente cogente aos particulares atenderem aos "convites" estatais. V. SUNSTEIN, Cass e THALER, Richard H. Nudge: Improving decisions about health, wealth and happiness, Chicago: Penguin books, 2009.
} 
facilitar a criação de microempresas, ao possibilitar financiamentos com baixas taxas de juros e diminuir a carga tributária sobre esse tipo de empreendimento.

O grande problema desse tipo de intervenção, porém, é a possível violação à livre-concorrência, à impessoalidade e à isonomia que podem ser causadas caso não se preste o devido cuidado quando se dá estímulos a determinado setor ${ }^{45}$. Frequentemente, a ausência de transparência quando da adoção de critérios de concessão de medidas de fomento tem o condão de trazer favorecimentos paternalistas a determinados agentes econômicos, terminando por representar uma intervenção estatal prejudicial, onde o Administrador escolhe quem serão os vencedores e quem serão os perdedores no regime supostamente concorrencial.

Um claro exemplo da sutil importância da atividade de fomento no Brasil é a atividade exercida pelo Banco Nacional do Desenvolvimento Econômico e Social - BNDES e pela Financiadora de Estudos e Projetos - FINEP. As empresas públicas federais exercem função primordial no surgimento e manutenção de pequenos negócios e projetos responsáveis por significativa e efetiva distribuição de recursos, uma vez que funcionam como financiadoras de negócios, que, sem o auxílio estatal, provavelmente não poderiam sair do papel. Oferecem-se taxas de juros muito abaixo daquelas do mercado privado, dando segurança financeira para seus clientes seguirem com seus negócios. Ocorre que, se os critérios de concessão desse estímulo não forem suficientemente rígidos e isonômicos e as taxas de juros forem demasiadamente baixas, o que se gera, na prática, é exatamente o efeito contrário daquele que se pretendia; o desestímulo à atividade empresária.

Explica-se. Um empreendimento privado que competiria com outro que, por sua vez, recebe auxílio governamental demasiadamente vantajoso ou baseado em fatores pessoais e nepotistas, não teria paridade de armas com seu concorrente. Assim, não compensaria o investimento para a concorrência, o que

\footnotetext{
45 "Existem dois grandes problemas circundando o fomento público: (i) os critérios de sua concessão e (ii) sua intensidade e duração. $O$ fomento pode ser inteligente instrumento de apoio ao desenvolvimento privado em direções social e constitucionalmente desejáveis - ou pode ser a enésima ajuda do Rei a seus amigos". MENDONÇA, José Vicente Santos de. op. cit. p. 116.
} 
desestimularia o crescimento econômico generalizado naquele setor, objetivo primário da atividade daquele auxílio.

Algumas atividades, ressalte-se, sequer se manteriam se deixadas a cargo exclusivo do mercado privado. O cinema, por exemplo, é uma indústria que jamais sobreviveria sem o incentivo gerado pelo Estado. Com exceção dos casos dos Estados Unidos e da Índia, todas as indústrias cinematográficas dependem, em algum grau, de fomento estatal ${ }^{46}$. Em casos como esse o fomento público se faz necessário, caso se considere de interesse público a manutenção da indústria, como parece ser o caso.

A despeito de ser de suma importância para a economia, o fomento público, muito provavelmente por conta da enorme discricionariedade a que lhe é atribuída tanto na sua concessão quanto na sua adesão, é escassamente estudado no âmbito jurídico, se comparado com as outras modalidades de intervenção estatal $^{47}$. Ocorre que não se pode ignorar que o fomento tem o condão de se tornar um instrumento relevantíssimo de efetividade dos direitos fundamentais por parte da Administração Pública, ainda que indiretamente e sua má-utilização pode, por outro lado, dar ensejo a atitudes nepotistas e paternalistas, se pondo contrariamente ao interesse público. Isso tudo reforça a noção de que se deve caminhar insistentemente no sentido de tornar o limite entre o fomento excessivo, adequado e escasso cada vez mais claro.

\subsubsection{Disciplina}

A atividade de disciplina, por seu turno, está diretamente relacionada à sua própria coercitividade. Diferentemente da modalidade de atuação de fomento, exposta acima, há uma imposição estatal em relação aos agentes econômicos, envolvendo, ainda, a fiscalização e outros derivados do poder de polícia ${ }^{48}$. O

\footnotetext{
${ }^{46} \mathrm{O}$ exemplo é de MENDONÇA. Cf. idem.

${ }^{47}$ Ibidem.

48 "Há, portanto, três poderes inerentes à regulação: aquele de editar a regra, o de assegurar a sua aplicação e o de reprimir as infrações, mesmo que esses infrações sejam dirigidas, inclusive, a empresas públicas ou ao próprio Estado agindo economicamente de forma direta em atividades típicas do setor privado". ARAGÃO, Alexandre dos Santos. op.cit. p. 26. É necessário se destacar, entretanto, a crítica do
} 
Estado atua, em outras palavras, como agente normativo e fiscalizador das interações econômicas de modo a organizá-las e condicionar o comportamento de seus agentes ${ }^{49}$. Daí, portanto, o nome atribuído a esse tipo de atividade; o Estado irá disciplinar a atividade econômica em geral através de leis e regulamentos, bem como da fiscalização do seu cumprimento.

A atuação de disciplina é uma tentativa de trazer equilíbrio ao sensível arcabouço principiológico da ordem econômica - constante no art. 170 da Constituição Federal ${ }^{50}$. Busca-se derrogar determinado princípio para que outro seja privilegiado e, assim, se possa atingir da forma mais adequada o interesse coletivo.

Exemplos desse tipo de intervenção são inúmeros e possuem todo tipo de origem; o Código de Defesa do Consumidor (Lei ${ }^{\circ}$ 8.078/90), por exemplo, se origina diretamente da Constituição, no art. $5^{\circ}, \mathrm{XXII}^{51}$, enquanto muitos regulamentos, por sua vez, têm origem infralegal, sendo emitidos por órgãos da administração indireta, como as agências reguladoras independentes ${ }^{52}$. Essa

emprego da expressão poder de polícia quando se faz referência à atividade ordenadora do Estado. "Desde logo é importante a questão do rótulo. Não convém falar em poder de polícia porque ele: a)remete a um poder - o de regular autonomamente as atividades privadas - de que a Administração dispunha antes do Estado de Direito e que, com sua implantação, foi transferido para o legislador; b) está ligada ao modelo do Estado liberal clássico, que só devia interferir na vida privada para regulá-la negativamente, impondo deveres de abstenção, e, atualmente a Constituição e as leis autorizam outros gêneros de imposição; c) faz supor a existência de um poder discricionário implícito para interferir na vida privada que, se pode existir em matéria de ordem pública - campo para o qual o conceito foi originalmente cunhado - não existe em outras, para as quais a doutrina transportou-o acriticamente, pela comodidade de seguir usando velhas teorias" SUNDFELD, Carlos Ari, Direito Administrativo Ordenador, 3 ed. São Paulo: Malheiros, 1997, p. 17.

${ }^{49}$ ARAGÃO, Alexandre dos Santos. op.cit. p. 26.

${ }^{50}$ Constituição Federal, art. 170: A ordem econômica, fundada na valorização do trabalho humano e na livre iniciativa, tem por fim assegurar a todos existência digna, conforme os ditames da justiça social, observados os seguintes princípios: I - soberania nacional; II - propriedade privada; III - função social da propriedade; IV - livre concorrência; V - defesa do consumidor; VI - defesa do meio ambiente, inclusive mediante tratamento diferenciado conforme o impacto ambiental dos produtos e serviços e de seus processos de elaboração e prestação; VII - redução das desigualdades regionais e sociais; VIII - busca do pleno emprego; IX - tratamento favorecido para as empresas de pequeno porte constituídas sob as leis brasileiras e que tenham sua sede e administração no País. (Redação dada pela Emenda Constitucional $n^{\circ}$ 6, de 1995) Parágrafo único: É assegurado a todos o livre exercício de qualquer atividade econômica, independentemente de autorização de órgãos públicos, salvo nos casos previstos em lei.

${ }^{51}$ Constituição Federal, art. $5^{\circ}$ : Todos são iguais perante a lei, sem distinção de qualquer natureza, garantindo-se aos brasileiros e aos estrangeiros residentes no País a inviolabilidade do direito à vida, à liberdade, à igualdade, à segurança e à propriedade, nos termos seguintes: XXXII - o Estado promoverá, na forma da lei, a defesa do consumidor;

52 Portarias Ministeriais, Decretos Executivos e Resoluções são formas comuns de se disciplinar determinados assuntos vistos como mais técnicos ou específicos. 
tendência, aliás, é ilustrativa de mais uma adaptação trazia pela ascensão do Estado Subsidiário; a descentralização da Administração Pública busca multiplicar os polos de regulação a fim de garantir maior independência a cada um deles ${ }^{53}$.

A atividade de disciplina - com auxílio da atividade de fomento - tem assumido posição central na atividade estatal, em detrimento dos modelos concebidos no Estado liberal, onde a qualquer atuação estatal era reprimida - e no Estado interventor - onde preferia-se que o Estado atuasse diretamente. Tal tendência em muito se relaciona com o desenvolvimento do atual modelo estatal que se adotou no Brasil - Estado regulador ou subsidiário -, onde se garante a livre iniciativa, a propriedade privada e a livre concorrência, ao mesmo passo que se favorece a função social da propriedade, a defesa do consumidor e a defesa do meio ambiente. Por um lado, não se pode conceber uma iniciativa privada nos moldes do Estado do laizes-faire, supostamente autossuficiente e ilimitável. Assim como, por outro, tampouco é concebível uma supressão à atividade privada ao ponto que seja extinta ou sufocada.

Com o compromisso constitucional assumido pelo Estado Brasileiro de concatenar esses princípios, surgiu a necessidade da adaptação do modelo estatal para um que permita a melhor convivência possível dos valores que inspiram ambos Estado liberais e Estado social. É possível afirmar que o principal mecanismo através do qual se dará a tão buscada conciliação entre esses princípios incompatíveis prima facie será a edição de normas que direcionem primordialmente - mas não apenas ${ }^{54}$ - a atuação privada, sem que essa seja suprimida e sem que se ignore a possibilidade de, em casos específicos, o Estado atue diretamente, através de empresas públicas, ou até mesmo, em casos extremos, monopólios, como será visto mais à frente.

\footnotetext{
${ }^{53}$ Sobre o ponto v. ARAGÃO. Alexandre dos Santos. op. cit. p. 412 e ss.

${ }^{54}$ Como se verá no item 1.4, as regulações também se aplicam aos entes estatais quando investidos nas atividades econômicas.
} 
O indício que melhor simboliza essa transformação do Estado, tanto no sentido de sua descentralização, quanto no sentido da emergência da sua atuação de regulação, sobretudo na atuação de disciplina, é o surgimento das agências reguladoras no país 55 .

É evidente que se trata de uma linha tênue, nem sempre corretamente delineada, podendo tender para um ou para outro lado a depender do caso concreto $^{56}$. É justamente esse o grande desafio da atuação de disciplina, o agente estatal responsável pela regulação - que, como se viu, pode partir dos mais variados polos decisórios - deve realizar o esforço de prever as consequências possíveis decorrentes daquela norma. Ademais, com o agigantamento da máquina estatal e o desenvolvimento da tecnologia - e sua importância para qualquer setor econômico -, essa tomada de decisão passou a ser cada vez mais específica e, quase sempre, técnica.

O estudo do direito público - administrativo ou constitucional regulatório atualmente ostenta posição indispensável nos debates jurídicos e traz consigo uma série de questões que, a despeito de serem altamente relevantes, não são comportadas no presente estudo. Temas como os limites da competência

\footnotetext{
${ }^{55} \mathrm{O}$ tema concernente às agências reguladoras é um demasiadamente extenso para os fins do presente estudo. Desse modo, convém apenas tecer breves comentários acerca de suas características principais. Nas palavras de MARILDA RIBEIRO: "As agências reguladoras foram trazidas pelas Emendas Constitucionais $\mathrm{n}^{\circ} 8$ e $\mathrm{n}^{\circ}$ 9, ambas de 1995, que inseriram o inciso XI no artigo 21 e o inciso III no parágrafo $2^{\circ}$ do artigo 177 da Constituição Federal a possibilidade de criação de um órgão regulador. Neste contexto, a lei que institui o ente regulador define a sua estrutura, atribuindo-se às agências reguladoras, na tradição brasileira a natureza autárquica. Merece destaque o fato de que essas entidades não são pura e simplesmente autarquias em sentido tradicional. Na verdade, as agências reguladoras possuem um regime autárquico diferenciado, ou especial, justamente para se conferir a elas maior autonomia e independência funcional. A autonomia e a independência importam em evitar ingerências políticas ou relação de captura pelo segmento controlado" RIBEIRO, Marilda Rosado de Sá. Direito do Petróleo. 3 ed. Rio de Janeiro: Renovar. 2014. p. 415.

${ }_{56}$ Apesar de se referir ao governo americano, a observação de SUNSTEIN também se aplica à experiência nacional. "Estamos em meio a um período de considerável in satisfação com o desempenho do governo federal. O aumento dos poderes presidenciais que se seguiu ao New Deal [no caso brasileiro, levando, inclusive a um período ditatorial] e a criação de uma enorme burocracia concentrada no ramo Executivo aumentaram o poder das facções (factional power) e a representação de interesses particularistas (self-interested representation), levando frequentemente a uma regulação que falha em servir os interesses do público em geral. De forma significativa, o governo federal termina ou regulando de mais ou regulando de menos". SUNSTEIN, Cass R. O Constitucionalismo após o The New Deal trad. Jean Paul Cabral Veiga da Rocha in Regulação Econômica e Democracia - O Debate Norte-Americano. Org. Paulo Mattos, São Paulo: Editora 34, 2004. p. 131.
} 
reguladora dos órgãos estatais ${ }^{57}$, controle de constitucionalidade dos atos regulatórios $^{58}$, a descentralização normativa e administrativa ${ }^{59}$, a independência das agências reguladoras ${ }^{60}$, a necessidade de coordenação normativa entre os órgãos regulatórios e o princípio da hierarquia ${ }^{61}$, entre outros, são recorrentes nesse meio e são de essencial papel para a compreensão exata da atividade de disciplina do Estado e sua problemática. Ocorre, porém, que a presente exposição não se volta exclusivamente ao tema, sendo um breve panorama da atividade de disciplina suficiente para o fim que se pretende.

\subsubsection{Atuação Direta}

A forma de intervenção mais relevante para os fins desse estudo é a atuação direta do Estado na atividade econômica. De início e, como já se viu, é imprescindível destacar que a ordem econômica é destinada e operada precipuamente pelos particulares ${ }^{62}$, segundo o próprio texto constitucional, quando este eleva a livre iniciativa ao patamar de princípio da ordem econômica. Daí se pode inferir ser devido aos indivíduos um direito subjetivo à livre concorrência e à busca do lucro ${ }^{63}$. Ocorre, porém, que não há qualquer incompatibilidade entre um sistema que nisso se pauta e eventuais exceções, nas quais o Estado, de modo excepcional, pode se imiscuir na atividade econômica de forma direta.

Diferentemente das modalidades acima descritas, o Estado aqui não vai criar nem incentivar a criação de balizas a serem seguidas pelos particulares. Em

\footnotetext{
${ }^{57}$ Sobre o tema v. BARROSO, Luis Roberto. A Ordem Econômica Constitucional e os Limites à Atuação Estatal no Controle de Preços. op. cit.

${ }^{58}$ Sobre o tema v. CYRINO, André Rodrigues. Direito Constitucional Regulatório: Elementos para uma Interpretação Institucionalmente adequada da Constituição Econômica Brasileira. Rio de Janeiro: Renovar, 2010.

${ }^{59}$ Sobre o tema v. ARAGÃO, Alexandre dos Santos. op. cit. p.203 e ss. e 412 e ss.

${ }^{60}$ Sobre o tema v. idem. p. 277.

${ }^{61}$ Sobre o tema v. BINENBOJM, Gustavo. op. cit. p. 288.

62 "A Constituição consagrou um regime capitalista, fundado nos princípios da livre iniciativa e livre concorrência. (...) Se o Estado pudesse assumir o desempenho direto das atividades econômicas propriamente ditas e a elas aplicar privilégios e benefícios, estaria destruída a distinção básica. Então, todas as atividades poderiam ser transformadas em serviço público". JUSTEN FILHO, Marçal. op. cit. p. 806.

${ }^{63}$ BARROSO, Luis Roberto. A Ordem Econômica Constitucional e os Limites à Atuação Estatal no Controle de Preços. p. 56.
} 
outras palavras, não será uma atuação através da qual o Estado tão somente delineará o mercado para que os players particulares possam nele atuar. Ele estará, na realidade, se investindo na qualidade de agente econômico por si mesmo e, na medida da razoabilidade, seguindo aquelas mesmas regras pensadas para os particulares. É uma faceta do Poder Público denominada de Estadoempresário.

As dificuldades atreladas a esse tipo de atuação são de singelo entendimento. Manter o tratamento isonômico entre Estado e particulares, bem como conciliar o lucro e interesse público são alguns dos aspectos que motivaram o constituinte a estabelecer circunstâncias consideravelmente específicas nas quais essa modalidade poderia ser exercida, devendo essas ser interpretadas restritivamente ${ }^{64}$.

A Constituição Federal, no caput de seu art. $173^{65}$ é expressa em admitir a atuação direta estatal na economia somente em três situações: $i$ ) os casos que nela já são elencados aprioristicamente; ii) as hipóteses onde haja imperativo de segurança nacional e iii) nas situações onde houver relevante interesse coletivo na atuação estatal.

No primeiro caso, o constituinte estabeleceu que em determinadas atividades econômicas, seria imprescindível ao interesse público que o Estado atuasse inicialmente sem a concorrência de particulares. Aceitou-se, assim, mitigar o princípio da livre iniciativa e livre concorrência em prol da virtude política e econômica da atividade em questão. Note-se, por oportuno, que se trata de uma decisão eminentemente política que visa diretamente garantir a soberania nacional ou outros valores essenciais ao país ${ }^{66}$. O exercício desse monopólio pode se dar no regime de competição (como passou a ser o setor do petróleo após

\footnotetext{
64 “A solução constitucional brasileira não deixa margem de dúvida. Somente em situações excepcionais o Estado desempenhará atividade econômica propriamente dita. E, quando o fizer, será inconstitucional criar qualquer privilégio em seu próprio benefício". JUSTEN FILHO, Marçal. op. cit. p. 808.

${ }^{65}$ Constituição Federal, art. 173: Ressalvados os casos previstos nesta Constituição, a exploração direta de atividade econômica pelo Estado só será permitida quando necessária aos imperativos da segurança nacional ou a relevante interesse coletivo, conforme definidos em lei.

${ }^{66}$ JUSTEN FILHO, Marçal. op. cit. p. 809.
} 
a emenda constitucional $n^{\circ}$ 9/95) ou em regime exclusivo (como é o caso do comércio de minérios e minerais nucleares e seus derivados).

Relevante destacar, é claro, que esse tipo de monopólio - o monopólio estatal - não se confunde com o monopólio privado, onde um agente detém controle de todo um setor econômico, e, fazendo uso dessa posição, cria mecanismos e empecilhos para propagar seu controle e impedir a entrada de competidores no mercado. Esse último, sim, se trata de uma afronta aos princípios da livre iniciativa e da livre concorrência, devendo ser reprimido em qualquer hipótese (através da atuação de disciplina do Estado, vista acima) ${ }^{67}$. Os monopólios estatais e as suas possíveis derrogações estão previstos no art. 177 da Constituição Federal $^{68-69}$.

No que diz respeito à segurança nacional, não poderia o constituinte deixar de abrir exceção também para casos extremos de instabilidade no cenário político nacional. As hipóteses de perda ou prejuízo à soberania do Estado Brasileiro e seus valores fundamentais justificariam uma conduta excepcional,

\footnotetext{
${ }^{67}$ CARVALHO FILHO, José dos Santos. Manual de Direito Administrativo, $27^{\mathrm{a}}$ ed. São Paulo: Atlas, 2014. p. 946.

${ }^{68}$ Constituição Federal, art. 170: Art. 177. Constituem monopólio da União: I - a pesquisa e a lavra das jazidas de petróleo e gás natural e outros hidrocarbonetos fluidos; II - a refinação do petróleo nacional ou estrangeiro; III - a importação e exportação dos produtos e derivados básicos resultantes das atividades previstas nos incisos anteriores; IV - o transporte marítimo do petróleo bruto de origem nacional ou de derivados básicos de petróleo produzidos no País, bem assim o transporte, por meio de conduto, de petróleo bruto, seus derivados e gás natural de qualquer origem; $\mathrm{V}$ - a pesquisa, a lavra, o enriquecimento, o reprocessamento, a industrialização e o comércio de minérios e minerais nucleares e seus derivados, com exceção dos radioisótopos cuja produção, comercialização e utilização poderão ser autorizadas sob regime de permissão, conforme as alíneas b e c do inciso XXIII do caput do art. 21 desta Constituição Federal. $\S 1^{\circ}$ A União poderá contratar com empresas estatais ou privadas a realização das atividades previstas nos incisos I a IV deste artigo observadas as condições estabelecidas em lei. $\S 2^{\circ}$ A lei a que se refere o $\S 1^{\circ}$ disporá sobre: $\mathrm{I}$ - a garantia do fornecimento dos derivados de petróleo em todo o território nacional; II - as condições de contratação; III - a estrutura e atribuições do órgão regulador do monopólio da União; $\S 3^{\circ}$ A lei disporá sobre o transporte e a utilização de materiais radioativos no território nacional. $\S 4^{\circ} \mathrm{A}$ lei que instituir contribuição de intervenção no domínio econômico relativa às atividades de importação ou comercialização de petróleo e seus derivados, gás natural e seus derivados e álcool combustível deverá atender aos seguintes requisitos: I - a alíquota da contribuição poderá ser: a) diferenciada por produto ou uso; b)reduzida e restabelecida por ato do Poder Executivo, não se lhe aplicando o disposto no art. 150,III, b; II - os recursos arrecadados serão destinados: a) ao pagamento de subsídios a preços ou transporte de álcool combustível, gás natural e seus derivados e derivados de petróleo; b) ao financiamento de projetos ambientais relacionados com a indústria do petróleo e do gás; c) ao financiamento de programas de infra-estrutura de transportes.

${ }^{69}$ Há debate doutrinário sobre o art. $25, \S 2^{\circ}$ da Constituição Federal. A questão gira em torno de saber se o gás canalizado representaria ou não mais um monopólio previsto constitucionalmente. O ponto não é relevante para o presente estudo, no entanto, é possível concluir que o caso se assemelha em tudo às hipóteses do art. 177 da Constituição Federal.
} 
qual seja, a atuação estatal direta no domínio econômico. O termo, é evidente, se trata de um conceito jurídico indeterminado ${ }^{70}$ e exige interpretação até certo ponto, subjetiva, porém, como já se viu, a hipótese deve ser examinada restritivamente, de modo que as zonas de incerteza gerada pela relatividade histórica e social da norma sejam ser excluídas de sua incidência ${ }^{71}$. O que se verifica, na prática, é que essa foi uma ressalva feita pelo constituinte que buscava abrir uma hipótese para uma conjectura ainda imprevisível, uma vez que quase todas as hipóteses que poderíamos associar com a segurança nacional já têm previsão constitucional e cuja titularidade foi conferida à União Federal ${ }^{72}$.

O relevante interesse coletivo, a exemplo da hipótese acima, também representa um conceito aberto a interpretações. Quanto ao ponto aplica-se todo o exposto no item 1.1, que trata do interesse público. Há, porém um adicional no texto constitucional que demonstra a excepcionalidade da medida, qual seja, o termo relevante. Nesse sentido, não se pode admitir atuação estatal diretamente no domínio econômico apenas se argumentando a persecução ao interesse público, esse deve ser relevante, emergencial, significativo ${ }^{73}$. Essa excepcionalidade não é por acaso e, como se exporá, à ordem econômica se aplica um princípio norteador decorrente da razoabilidade e filtro de qualquer atividade estatal na economia.

\footnotetext{
70 "Nem sempre convém, e às vezes é impossível, que a lei delimite com traços de absoluta nitidez o campo de incidência de uma regra jurídica, isto é, que descreva em termos pormenorizados e exaustivos todas as situações fáticas a que há de ligar-se este ou aquele efeito no mundo jurídico". MOREIRA, José Carlos Barbosa. Regras de experiência e conceitos juridicamente indeterminados, in Temas de direito processual, $2^{\text {a }}$ série. São Paulo: Saraiva, 1988. p. 64. No mesmo sentido: "Conceitos jurídicos indeterminados são expressões de sentido fluido, destinadas a lidar com situações nas quais o legislador não pôde ou não quis, no relato abstrato do enunciado normativo, especificar de forma detalhada suas hipóteses de incidência ou exaurir o comando a ser dele extraído. Por essa razão, socorre-se ele de locuções como as que constam na Constituição Brasileira de 1988, a saber: pluralismo político, desenvolvimento nacional, segurança pública, interesse público, interesse social, relevância e urgência, propriedade produtiva, em meio a muitas outras". BARROSO, Luís Roberto. Curso de Direito Constitucional Contemporâneo. op. cit. p. 339.

${ }^{71}$ A atuação só se justificaria, aliás, até o reestabelecimento da paz. CARVALHO FILHO, José Carvalho dos Santos. op. cit. p. 942.

${ }_{72}^{72}$ JUSTEN FILHO, Marçal. op. cit. p. 812.

${ }^{73}$ Idem
} 


\subsection{Princípio da Subsidiariedade}

O princípio da razoabilidade quando aplicado à atuação direta do Estado na Economia tem como consectário o princípio da subsidiariedade ${ }^{74}$. Segundo esse princípio, e isso pode ser extraído implicitamente do texto constitucional, o Estado só pode agir na economia quando sua atuação for imprescindível, não havendo outra solução para a persecução daquele fim de interesse coletivo e, ainda assim, quando o fizer deve fazê-lo da forma menos restritiva à liberdade individual possível ${ }^{75}$. Esse é um dos corolários extraídos do regime capitalista, acolhido pela República brasileira ${ }^{76}$.

É possível, assim, aplicar-se os mesmos parâmetros de $i$ ) adequação; $i$ ) necessidade e iii) proporcionalidade em sentido estrito, para se investigar a constitucionalidade de determinada medida interventiva por parte do Estado ${ }^{77}$. O princípio da subsidiariedade funciona, portanto, como um filtro de constitucionalidade da atuação estatal na economia, atuando como um mecanismo de proteção aos valores de preservação da propriedade privada, da livre iniciativa e da livre concorrência, mas, ao mesmo tempo, admitindo possibilidades onde esses valores possam, a depender do caso concreto, ser relativizados.

O princípio surge historicamente de mãos dadas à evolução do modelo estatal, sobretudo com a superação do modelo exclusivo do Estado social. Esse processo não se deu exclusivamente no Brasil, muito pelo contrário, o tema foi alvo de extensos debates e foi, posteriormente, positivado no Direito

\footnotetext{
${ }^{74}$ ARAGÃO, Alexandre dos Santos de. op. cit. p. 134.

75 Idem

${ }^{76} \mathrm{O}$ princípio da subsidiariedade se manifesta, na verdade, de diversas formas no ordenamento jurídico, tal como a autonomia que se procurou dar aos municípios, ou a criação das agências reguladoras o que demonstra a intenção de descentralização do aparato estatal. Foca-se, para os fins do presente estudo, porém, na dimensão que diz respeito exclusivamente à intervenção do Estado na Economia, mais especificamente à sua atuação direta. Sobre o tema v. WILEMAN, Marianna Montebello. O princípio da subsidiariedade e a redefinição do papel do estado no Brasil in Revista CEJ v. 615, Rio de Janeiro: América do Norte, 2008.

77 Sobre o princípio da razoabilidade, com farta indicação de bibliografia adicional sobre o tema, v. BARROSO, Luís Roberto. Curso de Direito Constitucional Contemporâneo. p. 328 e ss.
} 
Comunitário $^{78}$. O reconhecimento da ineficiência do corpo estatal quando inserido em ambiente de rápido desenvolvimento técnico e econômico, levou a um processo de "diminuição do gigantismo estatal", se revisse as faculdades do Poder Público, em especial na atividade econômica.

O princípio em comento se aplica a todo tipo de intervenção estatal, mas na atuação direta na economia se faz mais restritivo do que nas outras modalidades. É que a atuação direta, seja através dos monopólios previstos constitucionalmente, seja em função de risco à segurança nacional ou relevante interesse coletivo, representa, na prática, uma considerável supressão às liberdades individuais por ele protegidos, exigindo, por conseguinte, maiores precauções $^{80}$.

Como se viu pelas exigências descritas acima, o princípio encontra acolhida implicitamente no ordenamento constitucional brasileiro, que criou hipóteses restritas para a atuação direta do Estado, que representa o movimento contrário à tendência de "despaternalização" do Poder Público consoante com os valores vetores do Estado subsidiário ${ }^{81}$. O crescente desenvolvimento da atividade de fomento por parte do Poder Público - descrita acima -, aliás, está diretamente ligado a esse princípio, uma vez que, ao invés de tomar para si mais uma obrigação que não é capaz de prestar - como prover eficientemente determinado serviço público ou produto essencial - o Estado busca, através de incentivos, fomentar os agentes econômicos particulares a fazerem isso, o que, ao

\footnotetext{
78 A subsidiariedade foi elevada a princípio geral do direito comunitário pelo Tratado de Maastricht. Sobre o tema v. WILEMAN, Marianna Montebello. op. cit.

${ }^{79}$ Idem.

80 "Pues bien, el Estado de Derecho, con sus instituiciones y reglas, com las limitaciones que impone al poder público, sostiene la economía. Condición sine qua non para ello es que exista una sociedad libre y autônoma em la que las transacciones económicas se desarollen con operadores y protagonistas libres, distinctos y diferenciables del Estado. Esto es muy importante; el Estado puede ser 'un' agente económico, pero no absorber - ni dirigir - a 'todos' los agentes econômicos”. ORTIZ, Gaspar Ariño. Op. cit. p. 29.

${ }^{81}$ Como se viu, o Estado Subsidiário funciona no afã de conciliar os conflitos gerados pelo Estado liberal e o Estado do bem-estar social. É importante destacar que o princípio da subsidiariedade não representa um retrocesso ao liberalismo clássico. Muito ao revés, não se abomina a atuação estatal, o que se pretende é prover a oportunidade para a iniciativa privada agir primariamente, e, caso seus esforços se provem infrutíferos, abre-se a oportunidade de atuação para a atuação do Estado.
} 
menos aparentemente, tem sido a tendência com a veloz dinâmica da tecnicidade indispensável para a necessária eficiência econômica em qualquer setor ${ }^{82}$.

Dá-se espaço à iniciativa privada, já que se percebeu que, em regra, ela é mais apta a satisfazer os fins que dela se espera do que o Estado, que, por contar com recursos escassos, deve prestar todas as suas obrigações da forma mais eficiente possível, o que em uma conjectura de alto dinamismo técnico é inviável $^{83}$. A despeito de o Estado Democrático de Direito se obrigar com diversas garantias para o cidadão, isso não quer dizer que ele mesmo deve prestálas. Dar à iniciativa privada a possibilidade de fazê-lo, em muitos casos, é mais eficiente, no que diz respeito à satisfação de direitos fundamentais, do que tomar para si a incumbência; o que importa, em última instância é que eles sejam cumpridos, independendo se diretamente pelo Estado ou através da iniciativa privada $^{84}$ Esse tem sido o espírito do constituinte derivado que, através de diversas reformas, pôs a cabo uma série de privatizações e desmonopolizações que tinham como fim o privilégio da atuação privada em detrimento da atuação estatal.

Entre essas reformas, no que diz respeito ao enfoque do presente estudo, se destaca a já citada Emenda à Constituição nº 9/95, que flexibilizou o monopólio dado a várias empresas estatais, entre elas a Petrobras no mercado do petróleo $^{85}$. Como se pode concluir, o atual momento da empresa tem direta correlação com a ascensão do princípio da subsidiariedade que, por sua vez, é uma decorrência da evolução dos modelos de Estado. O mesmo pode se dizer

\footnotetext{
82 “Assim, prevalece, no regime constitucional brasileiro, o princípio da atuação residual do Estado, uma vez que compete à iniciativa privada a primazia na condução das atividades econômicas. Além de atuar residualmente, o Estado, enquanto empresário, somente pode exercer atividade econômica expressamente prevista na Constituição Federal ou em lei”. EIZIRIK, Nelson. A Lei das S/A Comentada, Volume III. São Paulo: Quartier Latin, 2011, p. 303.

83 “Outro ponto que merece destaque diz respeito à inconveniência de o Estado imiscuir-se nas atividades econômicas. Na verdade, sempre que o Estado intervém no domínio econômico se mostra ineficiente e incapaz de atingir seus objetivos, acabando por ocasionar uma série de outros problemas. Não há como comparar-se seus resultados com os obtidos pela iniciativa privada. (...) O que se verifica, um última instância, é que o Estado não deve mesmo exercer a função de explorar atividades econômicas. O papel que deve desempenhar é realmente o de Estado-Regulador, controlador e fiscal, mas deixando o desempenho às empresas de iniciativa privada”. CARVALHO FILHO, José dos Santos. op. cit. p. 942.

${ }^{84}$ ARAGÃO, Alexandre dos Santos de. op. cit. p. 136.

${ }^{85} \mathrm{O}$ tema será melhor descrito adiante, no ítem 4.2
} 
sobre o momento da empresa durante o período pré-emenda $\mathrm{n}^{\circ}$ 9/95, quando o Estado do bem-estar social valorizava menos a eficiência e a iniciativa privada, o que ensejou na criação de monopólio rígido no setor petrolífero.

\subsection{Atuação Direta, Regulação e Isonomia}

A complexidade do domínio econômico faz com que as modalidades de intervenção estatal nunca se deem de forma autônoma. Evidentemente, sempre que o Poder Público intervém na economia, ele cria repercussões para os particulares. Há, no entanto, maiores dificuldades quando há correlação entre as atividades de regulação - aí embarcando tanto a atuação de fomento (regulação indireta), quanto a atuação de disciplina (regulação direta) ${ }^{86}$ - e a atuação direta na economia.

Importante destacar desde início que o princípio da hierarquia ${ }^{87}$ se aplica também à Administração Indireta ${ }^{88}$. Isso quer dizer que, no que diz respeito à sua atividade exclusivamente administrativa, as empresas estatais se subordinam aos superiores hierárquicos da organização estatal que se organiza em formato piramidal e cujo topo é o chefe do Poder Executivo, o Presidente da República. Assim, os instrumentos estatais de intervenção direta na atividade econômica, estão permanentemente sujeitos à tutela administrativa e à respectiva supervisão ministerial $^{89}$ (a Petrobras, por exemplo, está sujeita à supervisão administrativa

\footnotetext{
86 “As regulações estatais da economia podem se valer de instrumentos puramente jurídico-coercitivos, ou combiná-los com mecanismos consensuais, econômicos, financeiros ou meramente materiais (...) o que faz com que possamos classificá-las, respectivamente, como 'regulações diretas' (...) e 'regulações indiretas"”. ARAGÃO, Alexandre dos Santos. op. cit. p. 39.

87 "O princípio da hierarquia, segundo o qual os poderes das autoridades administrativas exercem-se no sentido descendente do vértice para a base da pirâmide hierárquica, sendo a hierarquia a proposição que legitima a disposição e funcionamento das peças articulares da máquina administrativa, daí decorrendo o poder de dar ordens, de substituir, de fiscalizar, de rever atos, de aplicar sanções, de obedecer e de resolver conflitos, tudo fruto de uma unidade de direção”. SOUTO, Marcos Juruena Vilena. Direito Administrativo Contratual. Rio de Janeiro: Lumen Juris, 2004. p. 210.

88 “Todavia, o princípio do controle (...) tem significado mais amplo, uma vez que se constitui num dos três instrumentos da supervisão ministerial, a que estão sujeitos todos os órgãos da Administração Federal, inclusive os entes descentralizados, normalmente não submetidos ao poder hierárquico das autoridades da Administração direta". MEIRELLES, Hely Lopes. Direito administrativo brasileiro, $18^{\mathrm{a}}$ ed. São Paulo: Malheiros, 1993 p. 638.

${ }^{89}$ É nesse sentido que dispõe o art. 87, parágrafo único, inciso I da Constituição Federal. Confira-se seu conteúdo: Constituição Federal, art. 87: Os Ministros de Estado serão escolhidos dentre brasileiros maiores de vinte e um anos e no exercício dos direitos políticos. Parágrafo único. Compete ao Ministro de Estado, além de outras atribuições estabelecidas nesta Constituição e na lei: I - exercer a orientação,
} 
do Ministério das Minas e Energia ${ }^{90}$ ). A tutela administrativa interna, cujo propósito é meramente organizacional, não se confunde com a atividade de regulação estatal, uma vez que constitui tão somente um mecanismo intraadministrativo de coordenação, exclusivo para as entidades da Administração Pública e não uma intervenção no domínio econômico ${ }^{91}$. O presente tópico trata, portanto, do tema das regulações e como elas vão afetar sobre as empresas estatais.

Em primeiro lugar, é indispensável entender a problemática que permeia o assunto. O desenvolvimento do Estado subsidiário no Brasil, a despeito de diminuí-la, não encerrou a atuação direta estatal na economia. A convivência de modalidades interventivas faz com que o Estado exerça uma dúplice função sempre que atua em seu papel regulador; ao mesmo tempo em que o Poder Público é quem edita as regulações, quase sempre ele é também um de seus destinatários. Não se pode conceber, em atenção aos princípios constitucionais da isonomia e da livre concorrência, que o Estado (seja através de empresas federais, estaduais ou municipais), aufira vantagem não estendida aos particulares, sobretudo quando se refere à atuação direta no regime de competição. Desse modo, não apenas é desejável, como é essencial para a efetividade dos valores do Estado democrático de Direito, que as regulações destinadas aos particulares também se apliquem às empresas estatais no que couber.

Como se viu, um meio comum de atuação direta do Estado é a criação de monopólios relativos a determinados setores econômicos preestabelecidos na Constituição. Após a Emenda Constitucional n ${ }^{\circ}$ 9/95, tributária da ascensão do Estado subsidiário, esses monopólios foram flexibilizados ${ }^{92}$, de modo que se

coordenação e supervisão dos órgãos e entidades da administração federal na área de sua competência e referendar os atos e decretos assinados pelo Presidente da República.

${ }^{90}$ A despeito de não constar mais em seu estatuto, a vinculação ao Ministério de Minas e Energia, para fins de organização intra-administrativa ainda existe.

${ }^{91}$ ARAGÃ̃, Alexandre dos Santos de. op. cit. p. 38.

$92 \mathrm{O}$ ponto será analiticamente descrito adiante, especificamente no caso da Petrobras, no item 4.1. 
passou a admitir que as atividades, através de concessão ${ }^{93}$, fossem exercidas por particulares, o que, na prática, acabou com o monopólio de diversas empresas estatais. Com o objetivo de regular essas atividades que passariam a ser exercidas também pelos particulares, foram criadas a Agência Nacional do Petróleo, Gás Natural e Biocombustíveis - ANP e a Agência Nacional - ANA.

Essas agências passaram a regular os respectivos setores tanto para as empresas estatais quanto para as de iniciativa privada. Esses são os principais, mas não os únicos, polos de regulação que acabarão por afetar as empresas estatais em regime de competição econômica. É indispensável a atenção especial à manutenção da competição leal nesses âmbitos. Isso porque, a despeito de serem, em teoria, independentes, alheias a possíveis capturas de interesse por parte do governo, verifica-se, na prática, que não raramente as precauções tomadas para garantir a autonomia das agências reguladoras não são suficientes. Desse modo é essencial que se evite a utilização da qualidade reguladora estatal, combinada com a atuação direta via empresas públicas, como instrumentos de políticas públicas, sob pena de comprometimento dos valores democráticos.

\subsection{Conclusão do Capítulo}

A contextualização do processo que levou a Petrobras ao presente regime é diretamente ligada ao interesse público, à intervenção estatal e, notadamente, à atuação direta do Estado na economia, permeada pelo princípio da subsidiariedade. O estudo desses tópicos é indispensável para a correta compreensão das dimensões do debate. Entender o momento institucional histórico da nossa sociedade é entender os motivos pelos quais se chegou ao presente estado de coisas.

\footnotetext{
${ }^{93}$ Há críticas sobre a nomenclatura que se adotou. Segundo relevante doutrina, o termo "concessões" é destinado para a realização de serviços públicos por particulares, o que não é o caso dos contratos em evidência. Isso porque seu objeto não diz respeito a um serviço público, mas sim à realização de uma atividade econômica. Para um panorama completo com farta bibliografia sobre a polêmica v. ARAGÃO, Alexandre dos Santos de. op. cit. p. 158 e ss.
} 
Tudo isso para demonstrar que o tema extrapola o exame do direito positivo, merecendo reflexões para além da miopia formal positivista ${ }^{94}$. Apenas desse modo é possível se conceber uma sistematização capaz de diferenciar, quando necessário, o público do privado adequadamente, para que assim se possa passar para um exame mais práticos e aprofundado das repercussões oriundas desse embate. O momento atual clama, em todas as searas, por um estudo jurídico interdisciplinar.

O capítulo seguinte se dedica exatamente a algumas dessas consequências. Partindo dos conceitos já estabelecidos, se procurará demonstrar analiticamente as peculiaridades decorrentes o regime público clássico se comparados ao privado notadamente no âmbito contratual, onde as zonas de incerteza mais se destacam para que, mais a frente, se possa traçar conclusões acerca de cada um deles.

\footnotetext{
94 "De fato, se a resposta para os problemas não pode ser encontrada de maneira completa no comando que se encontra na legislação, é preciso procurá-la em outro lugar. E, assim, supera-se a separação profunda que o positivismo jurídico havia imposto entre o Direito e a Moral, entre o Direito e outros domínios do conhecimento. Para achar a resposta que a norma não fornece, o Direto precisa se aproximar da filosofia moral - em busca da justiça e de outros valores -, da filosofia política - em busca da legitimidade democrática e da realização de fins públicos que promovam o bem comum e, de certa forma, também das ciências sociais aplicadas, como economia, psicologia e sociologia. O pós-positivismo não retira a importância da lei, mas parte do pressuposto de que o Direto não cabe integralmente na norma jurídica e, mais do que isso, que a justiça pode estar além dela" BARROSO, Luís Roberto, Curso de Direito Constitucional Contemporâneo, op. cit. p. 334.
} 


\section{Capítulo 2 - Os Contratos Administrativos e o Regime Público: Das Cláusulas Exorbitantes à Licitação}

A personificação do Estado moderno como corpo coletivo permanente, capaz de conciliar a política e o direito, trouxe consigo o desenvolvimento da capacidade negocial do ente público, que passou a participar de empreendimentos que levam em conta a confluência da sua vontade com outros sujeitos de direito, rompendo com o modelo anterior onde a vontade unilateral do tirano se perfaria independentemente de qualquer pacto. O Estado, portanto, passou a ter a capacidade de adquirir direitos e contrair obrigações, na forma de prestação e contraprestação, enquanto pessoa de direito público ${ }^{95}$.

O meio através do qual tradicionalmente se instrumentaliza a manifestação bilateral de vontades entre privados é o contrato ${ }^{96}$. Com efeito, os principais corolários do direito contratual clássico consistem na autonomia da $\operatorname{vontade}^{97} \mathrm{e}$ na autoridade (força obrigatória) de suas disposições ${ }^{98}$, i.e., o contrato tem como objetivo primordial a instrumentalização e vinculação do livre acordo de vontade entre as partes contratantes. Ocorre que, em decorrência da natureza diferenciada do Estado, a cuja atuação típica se aplicam as regras do regime público, é inadmissível a prevalência indiscriminada da autonomia da vontade e do pacta sunt servanda, como se concebe tradicionalmente no âmbito privado ${ }^{99}$. Isso se

\footnotetext{
95 "O Estado é titular de direitos (direito de propriedade sobre prédio público, direito de punir os indivíduos, etc.) e de deveres (dever de pagar os vencimentos de seus funcionários, dever de respeitar a liberdade dos indivíduos etc.). Logo, o Estado é um centro unificador de direitos e deveres. Perante o Direito, é uma pessoa”. SUNDFELD, Carlos Ari. Fundamentos de Direito Público, 4ª ed. São Paulo: Malheiros, 2013. p. 65.

96 Para uma descrição histórica do instituto v. GOMES, Orlando. Contratos, $17^{\mathrm{a}}$ ed. Rio de Janeiro: Forense, 1996. p. 5 e ss.

97 “O princípio da autonomia da vontade particulariza-se no Direito Contratual na liberdade de contratar. Significa o poder dos indivíduos de suscitar, mediante declaração de vontade, efeitos reconhecidos e tutelados pela ordem jurídica. No exercício desse poder, toda pessoa capaz tem aptidão para provocar o nascimento de um direito ou para obrigar-se (...). Outros conceituam a autonomia da vontade como um aspecto da liberdade de contratar, no qual o poder atribuído aos particulares é o de se traçar determinada conduta para o futuro, relativamente às relações disciplinares da lei”. GOMES, Orlando. Contratos, 17 ed. Rio de Janeiro: Forense, 1996, p. 22.

98 "O princípio da força obrigatória consubstancia-se na regra de que o contrato é lei entre as partes". GOMES, Orlando. op. cit. p. 36.

99 Como é evidente, a autonomia da vontade não é princípio absoluto sequer no âmbito privado. "A liberdade de contratar, propriamente dita, jamais foi ilimitada. Duas limitações de caráter geral sempre
} 
dá, sobretudo por estar em jogo o interesse público, indisponível por natureza ${ }^{100}$. Daí, portanto, surge a necessidade da adaptação do instituto desenvolvido $a$ priori para a celebração de pactos consensuais bilaterais entre privados de modo a se compatibilizar, quando necessário, com o direito público, típico da atuação estatal.

\subsection{A classificação dos contratos da Administração Pública}

Os contratos da Administração Pública são, portanto, fruto da adaptação do instituto intrinsecamente privado que são os contratos, quando pertinente, ao regime público clássico. Pode se dizer, a fim de sistematizá-los, que segundo à doutrina tradicional, os contratos realizados pelo poder público compõem um gênero e se dividem em duas espécies; i) os contratos de direito privado da administração (ou contratos privados da administração); e ii) os contratos administrativos propriamente ditos (ou estrito senso) ${ }^{101}$.

Os contratos privados da administração seriam aqueles regidos pelo Direito Civil, onde o Poder Público se situa no mesmo plano jurídico do contratante, agindo no seu ius gestionis ${ }^{102}$, o que significa que, a princípio, há paridade entre as partes. Disso se extrai que a Administração Pública não gozaria das prerrogativas típicas do regime de direito público ${ }^{103}$, já que está lidando com o interesse público secundário explicado acima. Cita-se costumeiramente como

comfinaram-na: a ordem pública e os bons costumes. Entendia-se, como ainda se pensa, que as pessoas podem auto regular seus interesses pelo modo que lhes convenha, contando que não transponham esses limites”. GOMES, Orlando. Contratos, 17 ed. Rio de Janeiro: Forense, 1996. p. 24.

100 Observe-se as ressalvas expostas ao longo do item 1.1. A doutrina clássica, entretanto, ainda s guia pelo princípio: “Os bens e interesses públicos não pertencem à Administração nem a seus agentes. Cabelhes apenas geri-los, conservá-los e por eles velar em prol da coletividade, esta sim a verdadeira titular dos direitos e interesses públicos". CARVALHO FILHO, José dos Santos. op.cit. p. 36. E, no mesmo sentido, MELlo, Celso Antônio Bandeira de. Curso de Direito Administrativo, 30 a ed. São Paulo: Malheiros, 2013. p. 58 e ss.

${ }^{101}$ A classificação é, em sua substância, utilizada por José dos Santos Carvalho Filho (v. CARVALHO FILHO, José dos Santos. Manual de Direito Administrativo, $27^{\mathrm{a}}$ ed. São Paulo: Atlas, 2014. p. 173 e ss.), Celso Antônio Bandeira de Mello, Maria Sylvia Zanella Di Pietro, Hely Lopes Meirelles entre outros. Existem, entretanto, outras formas de sistematização do tema. Marçal Justen Filho, por exemplo, opta por denominar os ajustes onde o poder público figura em um dos polos como "contratos administrativos em sentido amplo", dividindo-os em "acordos de vontade da Administração", "contratos administrativos no sentido estrito" e "contratos de direito privado". JUSTEN FILHO, Marçal. op. cit. p. 420 e ss. A distinção entre elas, contudo, é materialmente irrelevante para os fins deste trabalho.

${ }^{102}$ CARVALHO FILHO, José dos Santos. op.cit. p. 174.

103 JUSTEN FILHO, Marçal. Curso de Direito Administrativo, $8^{\mathrm{a}}$ ed. Belo Horizonte: Fórum, 2012. p. 550 . 
exemplo para esses contratos a compra e venda ou locação de um imóvel entre o Poder Público e um particular com fim de lá instalar uma repartição pública ${ }^{104}$.

Os contratos administrativos propriamente ditos, por outro lado, são aqueles a que se aplicam as normas do Direito Público, estando sujeitos apenas subsidiariamente às normas de Direito Privado ${ }^{105}$. Nas palavras de CARVALHO FILHO, o contrato administrativo é "o ajuste firmado entre a Administração Pública e um particular regulado basicamente pelo direito público, e tendo uma atividade que, de alguma forma, traduza o interesse público" ${ }^{106}$. Em suma, um dos sujeitos da relação necessariamente é a Administração Pública, seu objeto se pauta obrigatoriamente pelo interesse público e o seu regime é o de Direito Público.

Tais contratos possuem disciplina normativa própria, responsável por promover a eles a aplicação dos institutos e princípios particulares do Direito Público. O principal diploma a compor o arcabouço legislativo dos contratos administrativos é a Lei $n^{\circ} 8.666 / 1993$, também conhecida como Estatuto dos Contratos e Licitações Públicas. É nessa lei que se encontram concentrados as normas e os princípios fundamentais que caracterizam o regime público a que eles se submetem ${ }^{107}$.

O diferencial entre os tipos de contratos realizados pelo poder público reside, como já se pôde concluir, pelo regime jurídico ao qual ele se submeterá. Os contratos privados da administração, evidentemente, se submetem primariamente às normas de Direito Privado, onde os já citados princípios da autonomia da vontade e da autoridade das disposições prevalecem. Os contratos administrativos propriamente ditos, a seu turno, se submetem às regras do Direito Privado, sobretudo às disposições e princípios contidos na Lei 8.666/93.

\footnotetext{
${ }^{104}$ MELLO, Celso Antônio Bandeira de. Curso de Direito Administrativo, 30a ed. São Paulo: Malheiros, 2013. p. 627.

${ }^{105}$ O ponto foi, aliás, positivado na Lei $\mathrm{n}^{\circ} 8.666 / 1993$, art. 54: Os contratos administrativos de que trata esta Lei regulam-se pelas suas cláusulas e pelos preceitos de direito público, aplicando-se-lhes, supletivamente, os princípios da teoria geral dos contratos e as disposições de direito privado.

${ }^{106}$ CARVALHO FILHO, José dos Santos, op. cit. p. 175.

${ }^{107}$ Idem. p. 177.
} 


\subsection{Características diferenciais dos contratos administrativos}

Como se vem de expor, os contratos administrativos possuem características próprias, oriundas do Direito Público, que os diferenciam de qualquer outra espécie do gênero contratos. Isso decorre, sobretudo da posição de preponderância da Administração Pública em relação à contraparte do vínculo contratual $^{108}$. E não poderia ser diferente: é que os interesses públicos têm, em regra, prevalência sobre os individuais ${ }^{109}$, e sendo o Estado, através da Administração Pública, o principal responsável pela tutela desses interesses, sua posição superior na relação contratual é consectário lógico. Registre-se, por oportuno, que a ressalva feita no primeiro capítulo, quanto ao princípio da supremacia do interesse público, é imprescindível para a correta compreensão do tema.

Feito o registro, o fato de lidar com o interesse público gera duas consequências diretas no regime jurídico dos contratos administrativos. Em primeiro lugar, cria a necessidade de, dentre os modelos contratuais tradicionais, se observarem modelos específicos que atendam aos princípios gerais de Direito Público. Em segundo, cria prerrogativas para o Estado perante a contraparte da relação além de determinadas obrigações que inexistem em contratos de outras naturezas.

\subsubsection{Características específicas típicas de contratos em geral}

Os contratos em geral ostentam diversas classificações possíveis ${ }^{110}$. Os administrativos, por sua vez, possuem especificidades quanto a esses tipos e modalidades, suportando apenas determinadas hipóteses. A primeira delas é o formalismo indispensável à sua formação. Não basta o consenso dos

\footnotetext{
108 “As normas de direito público outorgam ao ente incumbido de cuidar do interesse público (o Estado) posição de autoridade nas relações jurídicas que trave”. SUNDFELD, Carlos Ari. Fundamentos de Direito Público. op. cit. p. 69.

${ }^{109}$ DI PIETRO, Maria Sylvia Zanella. Direito Administrativo, $14^{\mathrm{a}}$ ed. São Paulo: Atlas, 2012. p. 69.

${ }^{110}$ Contratos sinalagmáticos (bilaterais), contratos atípicos, contratos comutativos, contratos aleatórios, contratos coligados, contratos de adesão, contratos formais (solenes), contratos consensuais, contratos onerosos, contratos gratuitos, contratos impessoais, contratos pessoais, contratos típicos, contratos atípicos, contratos de execução imediata, contratos de execução diferida, contratos principais, contratos acessórios, etc.
} 
contratantes, é imprescindível a observância de uma série de requisitos formais, tanto externos quanto internos, como, por exemplo, a forma escrita e a necessidade da realização - em regra - de licitação prévia à realização do contrato $^{111}$. Os contratos administrativos são necessariamente formais, eis que toda atividade administrativa exige formalismo.

Em segundo lugar, a comutatividade pressupõe o ajuste prévio e certo de prestação e contraprestação para ambas partes - bilateralidade -, havendo uma "relação entre vantagem e sacrifício subjetivamente equivalente"" Assim, veda-se, por parte da Administração Pública, a realização de contratos aleatórios, onde a alia determinará a proporção das obrigações a serem cumpridas. Os contratos administrativos, por conseguinte, têm obrigatoriamente de ser comutativos e bilaterais.

Os procedimentos licitatórios necessários, como regra geral, para a escolha do contratante mais apto para a realização de um contrato administrativo impõem a confiança recíproca à relação ${ }^{113}$. Com isso, pode-se concluir que os ajustes referidos são personalíssimos - intuito personae -, já que são contratos nos quais a pessoa com quem a Administração contrata é elemento causal para conclusão do contrato ${ }^{114}$. Como regra, portanto, as obrigações assumidas perante o Poder Público são intransferíveis. Além disso, pode-se dizer que o conteúdo dos contratos administrativos, por meio do instrumento convocatório da licitação, é fixado unilateralmente pela Administração, cabendo aos contratantes apenas aceitar ou não a oferta; i.e. trata-se de contratos de adesão ${ }^{115}$.

Levando em conta as modalidades contratuais descritas acima, torna-se indispensável à realização dos contratos administrativos a presença formal de determinadas disposições sem as quais o negócio jurídico por eles

\footnotetext{
${ }^{111}$ MEIRELLES, Hely Lopes. op. cit. p. 204.

${ }^{112}$ GOMES, Orlando. op. cit. p.74

${ }^{113}$ CARVALHO FILHO, José dos Santos. op. cit. p. 186.

${ }^{114}$ GOMES, Orlando. op. cit. p. 82.

${ }^{115}$ DI PIETRO, Maria Sylvia Zanella. op. cit. p. 254.
} 
instrumentalizado é inválido. O art. 55 da Lei $n^{\circ} 8.666 / 93^{116}$ elenca essas cláusulas necessárias (ou essenciais) a toda avença realizada pelo Poder Público (com exceção, é claro, dos contratos privados da Administração vistos acima). Registre-se, a presença dessas cláusulas no instrumento contratual é requisito formal de validade do contrato administrativo e não se confundem com as cláusulas exorbitantes, que serão analisadas detalhadamente no tópico seguinte.

\section{A última característica contratual que se aplica aos contratos} administrativos é a faculdade da Administração de exigir garantia do contratado nos contratos de obras, serviços e compras, como prevê o caput do art. 56 da lei das licitações e contratos públicos ${ }^{117}$. É necessário, para que seja válida a exigência de garantia, que haja previsão anterior, no instrumento convocatório, que não poderá exceder, em regra, a $5 \%$ do valor do contrato ${ }^{118}$ e que seja

\footnotetext{
${ }^{116}$ Lei $\mathrm{n}^{\circ} 8.666 / 93$, art. 55: São cláusulas necessárias em todo contrato as que estabeleçam:

I - o objeto e seus elementos característicos;

II - o regime de execução ou a forma de fornecimento;

III - o preço e as condições de pagamento, os critérios, data-base e periodicidade do reajustamento de preços, os critérios de atualização monetária entre a data do adimplemento das obrigações e a do efetivo pagamento;

IV - os prazos de início de etapas de execução, de conclusão, de entrega, de observação e de recebimento definitivo, conforme o caso;

V - o crédito pelo qual correrá a despesa, com a indicação da classificação funcional programática e da categoria econômica;

VI - as garantias oferecidas para assegurar sua plena execução, quando exigidas;

VII - os direitos e as responsabilidades das partes, as penalidades cabíveis e os valores das multas;

VIII - os casos de rescisão;

IX - o reconhecimento dos direitos da Administração, em caso de rescisão administrativa prevista no art.

77 desta Lei;

$\mathrm{X}$ - as condições de importação, a data e a taxa de câmbio para conversão, quando for o caso;

XI - a vinculação ao edital de licitação ou ao termo que a dispensou ou a inexigiu, ao convite e à proposta do licitante vencedor;

XII - a legislação aplicável à execução do contrato e especialmente aos casos omissos;

XIII - a obrigação do contratado de manter, durante toda a execução do contrato, em compatibilidade com as obrigações por ele assumidas, todas as condições de habilitação e qualificação exigidas na licitação. § $1^{\circ}$ (Vetado).

$\S 2^{\circ}$ : Nos contratos celebrados pela Administração Pública com pessoas físicas ou jurídicas, inclusive aquelas domiciliadas no estrangeiro, deverá constar necessariamente cláusula que declare competente o foro da sede da Administração para dirimir qualquer questão contratual, salvo o disposto no § 6o do art. 32 desta Lei.

$\S 3^{\circ}$ : No ato da liquidação da despesa, os serviços de contabilidade comunicarão, aos órgãos incumbidos da arrecadação e fiscalização de tributos da União, Estado ou Município, as características e os valores pagos, segundo o disposto no art. 63 da Lei no 4.320, de 17 de março de 1964.

${ }_{117}$ Lei $\mathrm{n}^{\circ} 8.666 / 93$, art. 56: A critério da autoridade competente, em cada caso, e desde que prevista no instrumento convocatório, poderá ser exigida prestação de garantia nas contratações de obras, serviços e compras (...).

${ }^{118}$ Há uma exceção em que se permite o aumento da garantia prevista. Confira-se o art. $56, \S 3^{\circ}$ da Lei ${ }^{\circ}$ 8.666/93: Para obras, serviços e fornecimentos de grande vulto envolvendo alta complexidade técnica e riscos financeiros consideráveis, demonstrados através de parecer tecnicamente aprovado pela autoridade
} 
realizada através de uma das modalidades de garantia previstas no $\S 1^{\circ}$ do art. 56 da mesma lei ${ }^{119}$.

\subsubsection{Cláusulas Exorbitantes}

Além das características referentes às modalidades típicas específicas do regime contratual geral, há uma peculiaridade ainda mais marcante exclusiva do regime contratual público. Como se disse anteriormente, a posição de preponderância da Administração advém da tutela do interesse público por ele promovida.

$\mathrm{Na}$ prática, tal posição é exercida através das chamadas cláusulas exorbitantes (também referidas como cláusulas de privilégio) ${ }^{120}$, inerentes a qualquer contrato administrativo - são essencialmente elas que compõem o regime contratual público ${ }^{121}$-, quer estejam implícitas ou explícitas, conferindo invariavelmente ao Estado prerrogativas ${ }^{122}$ no seio do contrato que, na maioria dos casos, sequer seriam lícitas em contratos privados ${ }^{123}$. Registre-se, entretanto, que, desde que derivadas de lei ou dos princípios que regem a atividade administrativa, as cláusulas exorbitantes são absolutamente válidas no contrato $\operatorname{administrativo~}^{124}$.

A opção da doutrina majoritária pela terminologia "exorbitante", aliás, pode ser explicada exatamente pelo fato de se tratarem cláusulas obrigatórias em

\footnotetext{
competente, o limite de garantia previsto no parágrafo anterior poderá ser elevado para até dez por cento do valor do contrato.

119 Lei n $n^{\circ} 8.666 / 93$, art. 56, $\$ 1^{\circ}$ : Caberá ao contratado optar por uma das seguintes modalidades de garantia: I - caução em dinheiro ou em títulos da dívida pública, devendo estes ter sido emitidos sob a forma escritural, mediante registro em sistema centralizado de liquidação e de custódia autorizado pelo Banco Central do Brasil e avaliados pelos seus valores econômicos, conforme definido pelo Ministério da Fazenda; II - seguro-garantia; III - fiança bancária.

120 "Data de então [do direito francês pós-revolucionário] a reitrodução da expressão romanista 'cláusulas exorbitantes', marcando simultaneamente a assimetria das relações e, à época, a distinção formal que se fazia entre os dois tipos de contratação: a privada e a pública". MOREIRA NETO, Diogo de Figueiredo. Mutações do Direito Administrativo. $3^{\mathrm{a}}$ ed. Rio de Janeiro: Renovar. 2007. p. 413..

${ }^{121}$ CARVALHO FILHO, José dos Santos. op. cit. p. 193.

122 "Prerrogativa" é o termo eleito pelo legislador na Lei $\mathrm{n}^{\circ}$ 8.666/93 para tratar das cláusulas exorbitantes. Veja-se o caput do art. 58 do diploma: $\mathrm{O}$ regime jurídico dos contratos administrativos instituído por esta Lei confere à Administração, em relação a eles, a prerrogativa de (...).

${ }^{123}$ Seriam as chamadas cláusulas potestativas, vedadas no regime privado em função do princípio da intangibilidade. Sobre o tema v. GOMES, Orlando. op.cit.p. 162 e ss.

${ }^{124}$ MEIRELLES, Hely Lopes. op. cit. p. 197.
} 
todo contrato administrativo que conferem poderes unilaterais a um dos contratantes - no caso, o Poder Público - que exorbitariam e desvirtuariam, no âmbito privado, os poderes das partes e a figura do contrato ${ }^{125}$. A lei $n^{\circ} 8.666 / 93$, em seu art. 58, enumera essas cláusulas. Confira-se seu conteúdo:

Art. 58: O regime jurídico dos contratos administrativos instituído por esta Lei confere à Administração, em relação a eles, a prerrogativa de:

I - modificá-los, unilateralmente, para melhor adequação às finalidades de interesse público, respeitados os direitos do contratado;

II - rescindi-los, unilateralmente, nos casos especificados no inciso I do art. 79 desta Lei;

III - fiscalizar-lhes a execução;

IV - aplicar sanções motivadas pela inexecução total ou parcial do ajuste;

V - nos casos de serviços essenciais, ocupar provisoriamente bens móveis, imóveis, pessoal e serviços vinculados ao objeto do contrato, na hipótese da necessidade de acautelar apuração administrativa de faltas contratuais pelo contratado, bem como na hipótese de rescisão do contrato administrativo.

$\S 1^{\circ}$ : As cláusulas econômico-financeiras e monetárias dos contratos administrativos não poderão ser alteradas sem prévia concordância do contratado.

$\S 2^{\circ}$ : Na hipótese do inciso I deste artigo, as cláusulas econômico-financeiras do contrato deverão ser revistas para que se mantenha o equilíbrio contratual.

Tem-se, portanto, que a Administração Pública é autorizada a instabilizar $^{126}$ o vínculo contratual, i) alterando-o unilateralmente; ii) rescindindo-o unilateralmente; $\mathbf{i i i ) ~ f i s c a l i z a n d o ~ d i r e t a m e n t e ~ s e u ~ c u m p r i m e n t o , ~ n o ~}$ exercício do poder de polícia estatal; iv) aplicando sanções que induzam ao cumprimento das obrigações contraídas; e v) em se tratando de serviço essencial, ocupando provisoriamente bens, pessoal e serviço vinculados ao objeto do contrato. As duas primeiras se destacam e serão expostas a seguir destacadamente.

\subsubsection{Alteração Unilateral do Contrato}

A primeira prerrogativa da Administração Pública se consubstancia na possibilidade de, unilateralmente, alterar qualitativamente ou quantitativamente o objeto do contrato administrativo. É evidente que a única motivação para que o Estado exerça essa prerrogativa é o interesse público. Fatos administrativos

\footnotetext{
${ }^{125}$ MELLO, Celso Antônio Bandeira de. op. cit. p. 634

${ }^{126}$ Idem. p. 627.
} 
supervenientes à formação contratual deveriam ser capazes de flexibilizar o vínculo, de modo a favorecer a coletividade representada pela Administração ${ }^{127}$.

As alterações qualitativas, como sugere a redação do art. 65 , I, a) da Lei $\mathrm{n}^{\circ} 8.666 / 93^{128}$ dizem respeito a modificações no projeto ou suas especificações para "melhor adequação técnica aos seus objetivos". As quantitativas, por sua vez, ocorrem quando se faz necessária a alteração do valor do contrato "em virtude do aumento ou diminuição quantitativa de seu objeto". Frise-se, no segundo caso, que a alteração só pode se dar em função do aumento ou diminuição do objeto, nunca pode ocorrer por si própria de forma direta, sendo, portanto alteração derivada, enquanto a alteração qualitativa constitui alteração primária $^{129}$.

O Poder Público não pode, porém, exercer essa prerrogativa de forma indiscriminada. A própria Lei $\mathrm{n}^{\circ} 8.666 / 93$ estabelece limites a seu exercício. Além da observância ao interesse público, já mencionada, é necessário que Estado se atenha ao limite de $25 \%$ do valor objeto do contrato inicialmente formulado, em geral e, em se tratando especificamente de reforma de edifício ou de equipamento, de $50 \%$ do valor inicial ${ }^{130}$. Qualquer alteração que ultrapasse esse valor exigirá, necessariamente, o consentimento do contratante e, ainda assim, só poderá se dar em caso de supressão, nunca acréscimo. Busca-se, através dessa norma, se preservar a incolumidade do procedimento licitatório realizado, de modo a prevenir desvios no seu objeto inicial.

\footnotetext{
${ }^{127}$ CARVALHO FILHO, José dos Santos. op.cit. p. 194

${ }^{128}$ Art. 65. Os contratos regidos por esta Lei poderão ser alterados, com as devidas justificativas, nos seguintes casos:

I - unilateralmente pela Administração:

a) quando houver modificação do projeto ou das especificações, para melhor adequação técnica aos seus objetivos;

b) quando necessária a modificação do valor contratual em decorrência de acréscimo ou diminuição quantitativa de seu objeto, nos limites permitidos por esta Lei; (...)

${ }^{129}$ A ressalva é de CARVALHO FILHO, José dos Santos. op. cit. p. 194.

${ }^{130}$ Lei $\mathrm{n}^{\circ} 8.666 / 93$, art. $65, \S 1^{\circ}$ : O contratado fica obrigado a aceitar, nas mesmas condições contratuais, os acréscimos ou supressões que se fizerem nas obras, serviços ou compras, até $25 \%$ (vinte e cinco por cento) do valor inicial atualizado do contrato, e, no caso particular de reforma de edifício ou de equipamento, até o limite de $50 \%$ (cinqüenta por cento) para os seus acréscimos.
} 
Outro ponto relevante relativo às alterações unilaterais nos contratos administrativos diz respeito à manutenção do equilíbrio econômico financeiro do vínculo. Com efeito, o $\$ 1^{\circ}$ do art. 58 da Lei $n^{\circ} 8.666 / 93^{131}$ determina que as cláusulas econômico-financeiras e monetárias das avenças não poderão ser alteradas de forma sem o consenso da outra parte. O parágrafo seguinte ${ }^{132}$ implica que, nos casos de alteração unilateral do contrato, essas cláusulas deverão "ser revistas de modo que se mantenha o equilíbrio contratual".

Surge, com isso, uma obrigação acessória para Administração a ser cumprida toda vez que ela exercer a sua prerrogativa de alteração unilateral do contrato administrativo. Ainda que a alteração se dê nos moldes do interesse público, o Estado é obrigado a rever as cláusulas econômico-financeiras de modo a que seja mantido o equilíbrio contratual estabelecido na sua formação. A ratio da norma é evitar o locupletamento injustificado por parte do erário e, ao mesmo tempo, a criação de uma desvantagem excessiva para a contraparte do contrato.

\subsubsection{Rescisão Unilateral do Contrato}

A Administração Pública pode também rescindir unilateralmente os contratos administrativos. $\mathrm{O}$ art. 78 da Lei $\mathrm{n}^{\circ} 8.666 / 93^{133}$ lista as hipóteses nas

\footnotetext{
${ }^{131}$ Lei $\mathrm{n}^{\circ}$ 8.666/93, art. 56, $\S 1^{\circ}$ : As cláusulas econômico-financeiras e monetárias dos contratos administrativos não poderão ser alteradas sem prévia concordância do contratado.

${ }^{132}$ Lei $^{\circ}{ }^{8} 8.666 / 93$, art. 56, $§ 2^{\mathrm{o}}$ : Na hipótese do inciso I deste artigo, as cláusulas econômico-financeiras do contrato deverão ser revistas para que se mantenha o equilíbrio contratual.

${ }^{133}$ Lei ${ }^{\circ} 8.666 / 93$, art. 78: Constituem motivo para rescisão do contrato:

I - o não cumprimento de cláusulas contratuais, especificações, projetos ou prazos;

II - o cumprimento irregular de cláusulas contratuais, especificações, projetos e prazos;

III - a lentidão do seu cumprimento, levando a Administração a comprovar a impossibilidade da conclusão da obra, do serviço ou do fornecimento, nos prazos estipulados;

IV - o atraso injustificado no início da obra, serviço ou fornecimento;

V - a paralisação da obra, do serviço ou do fornecimento, sem justa causa e prévia comunicação à Administração;

VI - a subcontratação total ou parcial do seu objeto, a associação do contratado com outrem, a cessão ou transferência, total ou parcial, bem como a fusão, cisão ou incorporação, não admitidas no edital e no contrato;

VII - o desatendimento das determinações regulares da autoridade designada para acompanhar e fiscalizar a sua execução, assim como as de seus superiores;

VIII - o cometimento reiterado de faltas na sua execução, anotadas na forma do $§ 1$ o do art. 67 desta Lei; IX - a decretação de falência ou a instauração de insolvência civil;

$\mathrm{X}$ - a dissolução da sociedade ou o falecimento do contratado;

XI - a alteração social ou a modificação da finalidade ou da estrutura da empresa, que prejudique a execução do contrato;
} 
quais o Estado pode exercer tal prerrogativa. É possível dividir essas hipóteses em quatro grupos ${ }^{134}$. O primeiro deles é relativo ao inadimplemento por parte do contratante, que abarca ambos o não cumprimento e o cumprimento irregular das cláusulas contratuais (inclusive algumas das situações específicas elencadas nos incisos seguintes - I a VIII -, como, por exemplo, "a paralisação da obra, do serviço ou do fornecimento, sem justa causa e prévia comunicação à Administração" ou "o atraso injustificado no início da obra, serviço ou fornecimento"). Em segundo lugar as situações que dizem respeito ao sujeito do contratante; mais especificamente o seu desaparecimento, sua insolvência ou sua impossibilidade de execução do contrato por razões societárias (incisos IX a XI). O terceiro grupo se apoia no interesse público (XII) e o quarto no caso fortuito ou de força maior (XVII).

Exclusivamente nos casos do inciso XII, que versa sobre a rescisão unilateral por razões de interesse público e XVII, que versa sobre caso fortuito, o erário terá que indenizar o particular. Isso porque nas outras hipóteses de rescisão unilateral, previstas no art. 78, há a culpa do contratante, fazendo com que, se houver prejuízo, a responsabilidade seja daquele cuja conduta deu ensejo à rescisão ${ }^{135}$. A Administração não poderia locupletar-se ilicitamente de particulares ao exigir qualquer tipo de reparação fundada no interesse público, eis que inexistente a culpa do contratante.

\subsubsection{Demais Cláusulas Exorbitantes}

Consectário do poder de polícia e da autotutela administrativa, a Administração Pública conta, ainda, com a prerrogativa de fiscalizar o cumprimento das cláusulas contratuais pelo contratante. Na verdade, é mais do

XII - razões de interesse público, de alta relevância e amplo conhecimento, justificadas e determinadas pela máxima autoridade da esfera administrativa a que está subordinado o contratante e exaradas no processo administrativo a que se refere o contrato;

(...)

XVII - a ocorrência de caso fortuito ou de força maior, regularmente comprovada, impeditiva da execução do contrato.

${ }^{134}$ DI PIETRO, Maria Sylvia Zanella. op. cit. p. 257.

${ }^{135}$ Idem. 
que uma prerrogativa, tratando-se de um poder-dever ${ }^{136}$. Isso porque a Lei $\mathrm{n}^{\circ}$ 8.666/93 determinou, em seu art. $67^{137}$, a exigência de ser apontado um agente público para fiscalizar o cumprimento dos contratos administrativos. É o modo pelo qual a Administração Pública irá garantir a observância ao interesse público ao longo da vigência do contrato.

O fiscal designado poderá, adicionalmente, determinar "o que for necessário para a regularização das faltas ou defeitos observados". Tais determinações são diretamente relacionáveis ao item anterior, já que o seu descumprimento pode acarretar a rescisão unilateral do contrato (art. 78, VII).

Seguindo a mesma linha, o art. 87 da Lei $\mathrm{n}^{\circ} 8.666 / 93^{138}$, por sua vez, regula as hipóteses de cabimento de sanções administrativas aplicadas ao contratante em caso de inexecução total ou parcial do contrato. Nos contratos

\footnotetext{
${ }^{136}$ CARVALHO FILHO, José dos Santos. op.cit. p. 35: "[A autotutela] não se trata apenas de uma faculdade, mas também de um dever, pois que não se pode admitir que, diante de situações irregulares, permaneça inerte e desinteressada. Na verdade, só restaurando a situação de regularidade é que a Administração observa o princípio da legalidade, do qual a autotutela é um dos mais importantes corolários".

${ }^{137}$ Lei $\mathrm{n}^{\circ}$ 8.666/93, art. 67: A execução do contrato deverá ser acompanhada e fiscalizada por um representante da Administração especialmente designado, permitida a contratação de terceiros para assisti-lo e subsidiá-lo de informações pertinentes a essa atribuição.

$\S 1^{\circ}$ : O representante da Administração anotará em registro próprio todas as ocorrências relacionadas com a execução do contrato, determinando o que for necessário à regularização das faltas ou defeitos observados.

$\S 2^{\circ}$ : As decisões e providências que ultrapassarem a competência do representante deverão ser solicitadas a seus superiores em tempo hábil para a adoção das medidas convenientes.

${ }^{138}$ Lei 8.666/93, art. 87: Pela inexecução total ou parcial do contrato a Administração poderá, garantida a prévia defesa, aplicar ao contratado as seguintes sanções:

I - advertência;

II - multa, na forma prevista no instrumento convocatório ou no contrato;

III - suspensão temporária de participação em licitação e impedimento de contratar com a Administração, por prazo não superior a 2 (dois) anos;

IV - declaração de inidoneidade para licitar ou contratar com a Administração Pública enquanto perdurarem os motivos determinantes da punição ou até que seja promovida a reabilitação perante a própria autoridade que aplicou a penalidade, que será concedida sempre que o contratado ressarcir a Administração pelos prejuízos resultantes e após decorrido o prazo da sanção aplicada com base no inciso anterior.

$\S 1^{\circ}$ : Se a multa aplicada for superior ao valor da garantia prestada, além da perda desta, responderá o contratado pela sua diferença, que será descontada dos pagamentos eventualmente devidos pela Administração ou cobrada judicialmente.

$\S 2^{\circ}$ : As sanções previstas nos incisos I, III e IV deste artigo poderão ser aplicadas juntamente com a do inciso II, facultada a defesa prévia do interessado, no respectivo processo, no prazo de 5 (cinco) dias úteis.

$\S 3^{\circ}$ : A sanção estabelecida no inciso IV deste artigo é de competência exclusiva do Ministro de Estado, do Secretário Estadual ou Municipal, conforme o caso, facultada a defesa do interessado no respectivo processo, no prazo de 10 (dez) dias da abertura de vista, podendo a reabilitação ser requerida após 2 (dois) anos de sua aplicação.
} 
privados é corriqueiro que as partes estabeleçam cláusulas penais ou outras sanções para o descumprimento de determinada obrigação, e isso é perfeitamente legal, inclusive nos contratos administrativos. A peculiaridade dessa prerrogativa, contudo, é que a Administração pode em determinadas hipóteses (incisos I, III e IV do art. 87) impor sanções ao particular independentemente de previsão contratual.

Por último, a Administração, quando se tratar de serviço essencial e em observância ao princípio da continuidade dos serviços públicos ${ }^{139}$, pode "ocupar provisoriamente bens móveis, imóveis, pessoal e serviços vinculados ao objeto do contrato" para averiguar os motivos que levaram o contratante a descumprir com suas obrigações. Em casos de rescisão unilateral, pode ainda o Poder Público, nos moldes do art. 80 da Lei ${ }^{\circ} 8.666 / 93^{140}$, tomar medidas de modo a se prossiga o mais rapidamente o serviço essencial objeto do contrato rescindido.

\subsubsection{Dever de Licitar}

O instituto da licitação pode ser analisado através de diversos escopos ${ }^{141}$. Juridicamente, porém, seu conceito poderia ser definido como "o processo administrativo pelo qual a Administração seleciona, por meio de habilitação de proponentes e julgamento objetivo de propostas, candidatos que com ela estão aptos a celebrar contratos (...)"142. A celebração dos contratos administrativos deve, portanto, ser precedida por licitação. A Constituição Federal estabelece

\footnotetext{
${ }^{139}$ DI PIETRO, Maria Sylvia Zanella. op. cit. p. 260.

${ }^{140}$ Lei $\mathrm{n}^{\circ}$ 8.666/93, art. 80: A rescisão de que trata o inciso I do artigo anterior acarreta as seguintes consequências, sem prejuízo das sanções previstas nesta Lei:

I - assunção imediata do objeto do contrato, no estado e local em que se encontrar, por ato próprio da Administração;

II - ocupação e utilização do local, instalações, equipamentos, material e pessoal empregados na execução do contrato, necessários à sua continuidade, na forma do inciso V do art. 58 desta Lei;

III - execução da garantia contratual, para ressarcimento da Administração, e dos valores das multas e indenizações a ela devidos;

IV - retenção dos créditos decorrentes do contrato até o limite dos prejuízos causados à Administração. (...)

141 "Pode-se, por exemplo, analisá-lo quanto ao aspecto econômico, com o objetivo de se obter a maximização dos recursos públicos ou o desenvolvimento do mercado; pode-se, ainda, apreciá-lo do ponto de vista da Ciência da Administração, a fim de se identificar as rotinas administrativas mais convenientes". DALLARI, Adilson Abreu. Aspectos jurídicos da Licitação, $4^{\mathrm{a}}$ ed. São Paulo: Saraiva, 1997, p. 2.

${ }^{142}$ SOUTO, Marcos Juruena Vilena. Direito Administrativo Contratual. Rio de Janeiro: Lumen Juris, 2004. p. 1.
} 
essa obrigatoriedade nos arts. 37 , inciso $\mathrm{XXI}^{143}$ e $175^{144}$. Note-se, o constituinte se utilizou de um termo técnico fechado, dotado de contornos normativos próprios $^{145}$ - licitação - para criar uma obrigação para a própria Administração Pública ${ }^{146}$, sem, contudo, defini-la.

A licitação conta com disciplina própria, dotada de princípios específicos que complementam aqueles gerais de direito público constantes do caput do art. 37 da Constituição Federal - legalidade, moralidade, publicidade, impessoalidade e eficiência que, aliás, são os justificadores da obrigatoriedade do procedimento licitatório. Os princípios da competição e da igualdade - que também poderiam ser considerados como princípios gerais ${ }^{147}$ - se alternam como os principais corolários segundo os quais todo procedimento licitatório deve se pautar. Resumidamente, a conjunção dos dois princípios tem o objetivo de garantir que a Administração possa identificar qual, entre todos os administrados potencialmente interessados, é capaz de oferecer a melhor proposta partindo de condições paritárias $^{148}$.

Os princípios específicos a serem observados antes, durante e após o procedimento licitatório podem ser divididos a partir de diversos critérios, havendo divergências doutrinárias quanto ao ponto. Parece certo, contudo, ser inafastável o princípio da vinculação do instrumento convocatório, que significa dizer que quaisquer que tenham sido as condições estabelecidas no edital ou convite, essas deverão ser preservadas, a fim de garantir a segurança jurídica e

\footnotetext{
${ }^{143}$ Constituição Federal, art. 37: A administração pública direta e indireta de qualquer dos Poderes da União, dos Estados, do Distrito Federal e dos Municípios obedecerá aos princípios de legalidade, impessoalidade, moralidade, publicidade e eficiência e, também, ao seguinte: (...)

XXI - ressalvados os casos especificados na legislação, as obras, serviços, compras e alienações serão contratados mediante processo de licitação pública que assegure igualdade de condições a todos os concorrentes, com cláusulas que estabeleçam obrigações de pagamento, mantidas as condições efetivas da proposta, nos termos da lei, o qual somente permitirá as exigências de qualificação técnica e econômica indispensáveis à garantia do cumprimento das obrigações (...).

${ }^{144}$ Constituição Federal, art. 175: Incumbe ao Poder Público, na forma da lei, diretamente ou sob regime de concessão ou permissão, sempre através de licitação, a prestação de serviços públicos. (...)

145 BRITTO, Carlos Ayres. O Perfil Constitucional da Licitação. Curitiba: ZNT, 1997, p. 10.

146 “A licitação, se do ponto de vista legislativo é uma competência, do ponto de vista administrativo é um puro dever (...) Modalidade típica de situação jurídica passiva do Estado-administração”. Idem.

${ }_{147}^{14}$ V. DALLARI, Adilson de Abreu. Aspectos jurídicos da Licitação. op.cit. p. 36.

148 MOREIRA NETO, Diogo de Figueiredo. Curso de Direito Administrativo. 14 ${ }^{\mathrm{a}}$ ed. Rio de Janeiro: Forense. 2005. p. 179.
} 
previsibilidade das consequências que decorrerão do certame licitatório. Aliado a esse princípio, comumente se faz referência ao princípio da objetividade do julgamento $^{149}$, segundo o qual o julgamento se dará levando em conta a aplicação objetiva dos critérios já estabelecidos. Além dos já citados, são correntes os princípios do sigilo das propostas e do respeito ao procedimento formal, que têm igualmente o objetivo de preservar a lisura e eficiência do certame.

Assim como os contratos administrativos em geral, as licitações são disciplinadas pela Lei $n^{\circ} 8.666 / 93$. Lá se encontram os dispositivos gerais a serem observados em toda licitação e as possíveis modalidades ${ }^{150}$. É importante destacar quanto ao ponto a competência legislativa exclusiva da União para estabelecer as normas gerais de licitação, conforme o art. 22, XXVII ${ }^{151}$, cabendo mutatis mutandi, aos demais entes legislar apenas sobre normas específicas, desde que não violem qualquer disposição das normas gerais federais. Outra questão de relevo no tocante à legislação licitatória, diz respeito à Lei $\mathrm{n}^{\circ} 12.462 / 11$, que criou o Regime Diferenciado de Contratação - RDC -, que inseriu um novo regime licitatório mais flexível em função da realização de grandes eventos esportivos no país que exigiam maior dinâmica, sobretudo na realização de obras. Tal norma - assim como a Lei $\mathrm{n}^{\circ} 10.520 / 02$, que inseriu a modalidade licitatória do pregão - é de natureza específica, atuando a Lei $\mathrm{n}^{\circ}$ $8.666 / 93$ supletivamente ao nelas disposto.

Como qualquer outro, o princípio da licitação não é absoluto, de modo que a própria Constituição, no art. 37, XXI, prevê a hipótese de criação de exceções à

\footnotetext{
${ }^{149}$ V. AMARAL, Flávio Garcia, Licitações e Contratos Administrativos (Casos e Polêmicas). Rio de Janeiro: Lumen Iuris. 2007. p. 7 e, no mesmo sentido, MOREIRA NETO, Diogo de Figueiredo. op. cit. p. 180. Para DALLARI, por outro lado, a objetividade é mera consequência da observância de três princípios específicos, quais sejam, a igualdade, a publicidade e a estrita observância do instrumento de abertura (vinculação ao instrumento convocatório). V. DALLARI, Adilson de Abreu. Aspectos jurídicos da Licitação. op. cit. p. 37.

${ }^{150}$ A Lei $\mathrm{n}^{\circ} 10.520 / 2002$ adicionou a modalidade pregão ao rol das modalidades já previstas pela lei geral, de modo que atualmente não estão todas as modalidades licitatórias previstas na Lei n 8.666/93.

${ }^{151}$ Constituição Federal, art. 22: Compete privativamente à União legislar sobre: (...)

XXVII - normas gerais de licitação e contratação, em todas as modalidades, para as administrações públicas diretas, autárquicas e fundacionais da União, Estados, Distrito Federal e Municípios, obedecido o disposto no art. 37, XXI, e para as empresas públicas e sociedades de economia mista, nos termos do art. $173, \S 1^{\circ}, \mathrm{III} ;(\ldots)$
} 
obrigatoriedade de realização do certame licitatório pela legislação ${ }^{152}$. São duas as exceções $\left.{ }^{153} ; \boldsymbol{i}\right)$ a dispensa de licitação, onde poderia ser realizada o certame, mas por uma conjectura específica, prevista em lei, se admite que ele não seja realizado, sobretudo por ser indesejável que ele o seja e ii) a inexigibilidade de licitação, que se dá nos casos onde há, por determinada circunstância, uma inviabilidade de cunho lógico.

A dispensa de licitação tem suas hipóteses previstas no art. 24 da Lei 8.666/93. Não é compatível com o objeto do presente estudo analisar cada um dos casos do extenso rol previsto, basta destacar que o legislador, respeitando o imperativo constitucional, previu uma grande quantidade de hipóteses de dispensa de licitação, de modo a permitir uma dinâmica adequada ao administrador quando da realização de determinados contratos administrativos.

A inexigibilidade de licitação, prevista no artigo seguinte ${ }^{154}$, como se viu, lida com as hipóteses nas quais é inviável a própria competição. O rol do art. 25 do Estatuto, como se depreende da sua própria redação ao usar o vocábulo "em

\footnotetext{
${ }^{152}$ Adilson de Abreu Dallari atenta para o caráter de exceção da não obrigatoriedade, lembrando que essa interpretação sempre deverá, por pressuposto lógico hermenêutico, ser tratada restritivamente. DALLARI, Adilson de Abreu. Aspectos jurídicos da Licitação. op. cit. p. 45.

${ }^{153}$ MEIRELLES e outros autores falam sobre a licitação dispensada, a diferenciando da licitação dispensável (a primeira seria o caso no qual a própria lei dispensa e a segunda, por sua vez, seria as hipóteses nas quais a lei faculta ao administrador dispensá-la). Há também menção à licitação vedada, que existia anteriormente à Lei 8.666/93, em função de previsão do dec. 2300/1986, e se referia aos casos onde a segurança nacional pudesse estar comprometida. MEIRELLES, Hely Lopes. Licitação $e$ o Contrato Administrativo, op. cit., p. 92.

${ }^{154}$ Lei ${ }^{\circ}$ 8.666/93, art. 25: É inexigível a licitação quando houver inviabilidade de competição, em especial:

I - para aquisição de materiais, equipamentos, ou gêneros que só possam ser fornecidos por produtor, empresa ou representante comercial exclusivo, vedada a preferência de marca, devendo a comprovação de exclusividade ser feita através de atestado fornecido pelo órgão de registro do comércio do local em que se realizaria a licitação ou a obra ou o serviço, pelo Sindicato, Federação ou Confederação Patronal, ou, ainda, pelas entidades equivalentes;

II - para a contratação de serviços técnicos enumerados no art. 13 desta Lei, de natureza singular, com profissionais ou empresas de notória especialização, vedada a inexigibilidade para serviços de publicidade e divulgação;

III - para contratação de profissional de qualquer setor artístico, diretamente ou através de empresário exclusivo, desde que consagrado pela crítica especializada ou pela opinião pública.

$\S 1^{\circ}$ : Considera-se de notória especialização o profissional ou empresa cujo conceito no campo de sua especialidade, decorrente de desempenho anterior, estudos, experiências, publicações, organização, aparelhamento, equipe técnica, ou de outros requisitos relacionados com suas atividades, permita inferir que o seu trabalho é essencial e indiscutivelmente o mais adequado à plena satisfação do objeto do contrato.

$\S 2^{\circ}$ : Na hipótese deste artigo e em qualquer dos casos de dispensa, se comprovado superfaturamento, respondem solidariamente pelo dano causado à Fazenda Pública o fornecedor ou o prestador de serviços e o agente público responsável, sem prejuízo de outras sanções legais cabíveis.
} 
especial", é exemplificativo, até porque não se poderia esperar do legislador que fosse capaz de prever todas as hipóteses nas quais a competição se torna inviável. Ressalte-se mais uma vez, as hipóteses de não obrigatoriedade do procedimento licitatório são a exceção à regra geral, não devendo ser utilizadas com o fím de permitir que o administrador se esquive do seu dever de licitar. Exatamente por isso se faz indispensável a adoção de um regime licitatório sensível às peculiaridades dos negócios que podem ser celebrados pela Administração Pública, sempre levando em conta que, em algumas hipóteses - como o desempenho de atividades com regime de competição -, estabelecer parâmetros demasiadamente rígidos acabam por paradoxalmente impor, por si só, uma inviabilidade à competição ${ }^{155}$.

O procedimento da licitação em si envolve fases burocráticas (fase do edital, da habilitação, do procedimento seletivo e da homologação e adjudicação) repletas de formalidades e conta com modalidades próprias, todas preestabelecidas no Estatuto ${ }^{156}$, além de fatores e critérios (conjugação dos fatores levados em consideração ${ }^{157}$ ) definidos a priori no instrumento de convocação através dos quais se definirá qual é a melhor oferta.

Como se vê, ao longo do certame, notadamente o que se dá nos moldes da Lei $\mathrm{n}^{\circ}$ 8.666/93, o administrador se vê vinculado a uma série de requisitos formais dos quais não pode abrir mão, sob pena de cometer ilegalidades. A despeito da clara desvantagem materializada no engessamento da atividade administrativa, não se pode supor que licitação não se justifica. A fim de evitar distorções na administração dos recursos públicos e respeitar os princípios republicano e os justificadores do Direito Público, a licitação se faz imprescindível à atividade contratual administrativa. O princípio da livre

\footnotetext{
${ }^{155}$ SUNDFELD, Carlos Ari e SOUZA, Rodrigo Pangani, Licitações nas Estatais: Levando a Natureza Empresarial a Sério, in Revista de Direito Administrativo, vol. 245. Rio de Janeiro: Atlas, 2007. p. 15.

${ }^{156}$ As modalidades previstas na $\mathrm{n}^{\circ}$ Lei 8.666/93 são: a concorrência, a tomada de preços, o convite, o concurso e o leilão.

${ }^{157}$ CARVALHO FILHO, José dos Santos. op. cit. p. 294.
} 
concorrência (art. 170, IV da Constituição Federal ${ }^{158}$ ), por exemplo, está diretamente ligado à sua realização, uma vez que é o modo pelo qual se impede o favorecimento a esse ou àquele competidor por motivos obscuros e garante a todos a mesma oportunidade de contratar ${ }^{159}$.

A realização de licitação, portanto, quando adequadamente utilizada, tem o potencial de evitar corrupção e danos desnecessários ao erário, uma vez que é extremamente comum para os administradores públicos confundirem a persecução ao interesse público primário com o secundário e, ainda mais grave, com o seu interesse particular. Desse modo, a regra para os contratos administrativos deve, de fato, ser a obrigatoriedade do procedimento licitatório prévio, desde que isso não enseje em outro tipo de distorção maniqueísta que traga prejuízos ainda maiores pelo seu excesso de rigidez, por exemplo.

É esse o grande desafio para o legislador, que, ao estabelecer os parâmetros para a realização dos certames, influi diretamente na atividade administrativa. A rigidez ou flexibilidade do procedimento deve ser condizente com o negócio jurídico a ser realizado, sob o risco de, por um lado, sufocar atividades empresariais, incapacitando a competição, quando for o caso, por parte do poder público, ou, por outro, permitindo violações ao princípio republicano, à livre concorrência e aos princípios da Administração Pública ao ensejar a realização de negócios jurídicos arbitrários.

\subsection{Conclusão do Capítulo}

A exata compreensão da diferença entre os regimes público e privado na concepção clássica do Direito Administrativo é essencial para entender as consequências jurídicas para a adoção de cada um deles. Como se expôs, a Lei $n^{\circ}$ 8.666/93 traz as principais disposições acerca do tema "contrato administrativo", definindo uma série de prerrogativas para a Administração Pública, além de

\footnotetext{
${ }^{158}$ Constituição Federal, art. 170: A ordem econômica, fundada na valorização do trabalho humano e na livre iniciativa, tem por fim assegurar a todos existência digna, conforme os ditames da justiça social, observados os seguintes princípios: (...) IV - livre concorrência; (...).

${ }^{159}$ SOUTO, Marcos Juruena Villela. op. cit. p. 6.
} 
impor procedimento licitatório prévio à contratação. Tais prerrogativas se justificam em decorrência dos princípios administrativos que permeiam a atividade estatal. Ao passo que constituem à primeira vista vantagem para a atuação pública, porém, admitir sua incidência em situações que clamam pela preponderância do regime privado, ensejará invariavelmente consequências perversas, prejudicando não apenas o erário, como também a coletividade como um todo ${ }^{160}$. Saber a diferenças práticas entre o regime contratual privado e o regime contratual público é o primeiro passo para compreender o quão é relevante a correta aplicação dos institutos relativos a cada um deles e quando é cabível sua diferenciação.

É instintivo que a criação de vantagens desmedidas para o Estado em um ambiente de competição terá como condão afastar os possíveis pretendentes a realizar negócios, afinal seria mais seguro contratar com outro competidor, que não gozará, por exemplo, da habilidade de unilateralmente alterar o objeto do contrato. Igualmente prejudicial seria impor o tão necessário trajeto burocrático $^{161}$ ao contratante em um cenário dinâmico e sofisticado como o mercado privado, constituiria para ele um fardo insuportável.

Como se vê, as prerrogativas estatais têm um custo para o próprio Estado $^{162}$, eis que serão levadas em conta no momento da contratação, afetando o

\footnotetext{
160 Ficam prejudicados com isso ambos o interesse público primário e o secundário, remontando à classificação de Renato Alessi exposta no tópico 1.1.

${ }^{161}$ A noção da função da burocracia como meio de dominação na atividade institucional, sobretudo a estatal remonta a WEBER, Max. Economia e Sociedade, Vol. II. (trad. Regis Barbosa). São Paulo: UNB. 2011, p 198. Para o autor a estabilidade proporcionada pelo aparato burocrático possibilita a confiança e o consequente domínio e sujeição dos indivíduos a determinada instituição. O Estado, como se supõe, é a maior de todas as instituições, sendo, por conseguinte, o principal beneficiário e demandante da burocracia.

${ }^{162} \mathrm{O}$ princípio da eficiência é um dos princípios constitucionais da Administração Pública constantes do caput do art. 37. Tributário da evolução do papel da Administração, que não mais se adstringe ao mero respeito à lei, o princípio da eficiência surge em função da emergência dos direitos fundamentais, sobretudo os sociais, que passam a figurar entre as obrigações estatais perante a coletividade. Nesse escopo, torna-se imprescindível que o Estado aja da maneira mais eficiente possível, levando em conta, por exemplo, os custos das prerrogativas e obrigações inerentes à sua atividade na ponderação respectiva, caso contrário, não terá capacidade econômica para tutelar os direitos fundamentais a que se propõe defender. Sobre o tema v. ARAGÃO, Alexandre dos Santos. O Princípio da Eficiência. Revista Eletrônica de Direito Administrativo Econômico $n^{\circ}$ 4, Salvador: Instituto de Direito Público da Bahia, 2006 e, no mesmo sentido, MOREIRA NETO, Diogo de Figueiredo. Quatro Paradigmas do Direito Administrativo pós-moderno: Legitimidade, Finalidade, Eficiência e Resultados. Belo Horizonte: Fórum, 2008.
} 
montante e até mesmo a existência da contratação em si. Quando se está diante de uma atividade econômica, suscetível à concorrência, a burocracia estatal deve ser mitigada. Delimitar as fronteiras dessa mitigação, contudo, constitui um dos grandes desafios da intervenção do Estado na economia. Isso porque, se de um lado a aplicação dos privilégios e do procedimento licitatório pode prejudicar o interesse coletivo se utilizada em demasia, por outro, quando prescindidos inadequadamente, podem dar ensejos a consequências igualmente temerárias, afinal, e como se viu, a burocracia e a posição superior do Estado são, como regra, essenciais para o funcionamento adequado do ente ${ }^{163}$.

Os capítulos seguintes se destinam ao estudo das sociedades de economia mista e, em especial, ao caso da Petrobrás. Nesse âmbito há, tanto na doutrina quanto na jurisprudência, relevante controvérsia sobre a aplicação dos ditames da Lei $\mathrm{n}^{\circ} 8.666 / 93$ a essas sociedades. Como se supõe, a polêmica, em última instância, gira exatamente em torno da aplicabilidade, ou não, de cada um dos regimes aos contratos celebrados.

\footnotetext{
${ }^{163}$ Nesse sentido, demonstrando as atuais tendências de diminuição da essencialidade das cláusulas exorbitantes e flexibilização do sistema de regime público fechado: "As vantagens para a Administração eram então inegáveis na vigência do sistema vigente de economia semidirigida, pois as cláusulas exorbitantes com eles se coadunavam, sob o pálio do conceito de supremacia indiscriminada do Estado [como se viu no item 1.1], ideia força que orientava a busca de autossuficiência estatal e o seu progressivo aparelhamento para lograr a substituição de importações e estatização da economia. Evidentemente, nesse contexto a economia preponderantemente fechada, explicava-se a baixa preocupação com a competitividade por capitais e tecnologias, pois os aparelhos estatais aspiravam a gerá-los eles próprios a partir de políticas públicas dirigistas, praticadas conforme as nuanças do regime político - mais fechado ou mais aberto - que tivesse sido adotado". MOREIRA NETO, Diogo de Figueiredo. Mutações do Direito Administrativo. op. cit. p. 418.
} 


\section{SEGUNDA PARTE}

\section{Capítulo 3 - As Sociedades de Economia Mista}

Antes de adentrar no caso específico da Petrobrás e seus contratos, se faz imprescindível a análise das peculiaridades do regime aplicável às sociedades de economia mista em geral. Isso porque a essas empresas aplicam-se determinados aspectos do Direito Público, sobretudo no que concerne a aplicação dos princípios contidos no caput do art. 37 da Constituição Federal e a persecução do interesse coletivo.

Ao mesmo tempo, contudo, por se tratarem de sociedades anônimas inseridas, em regra, no desempenho excepcional de atividade econômica pelo Estado $^{164}$, o interesse dos outros acionistas que não a Administração, materializado na forma do lucro, configura objeto de igual importância a ser perseguido. Trata-se, portanto, de um regime híbrido destinado à difícil tarefa de conciliar o interesse público com o lucro.

Essa peculiaridade cria, especificamente no âmbito contratual, algumas implicações de repercussões essenciais para a economia nacional, ante a importância dessas empresas no país.

\footnotetext{
164 Art. 173. Ressalvados os casos previstos nesta Constituição, a exploração direta de atividade econômica pelo Estado só será permitida quando necessária aos imperativos da segurança nacional ou a relevante interesse coletivo, conforme definidos em lei.

$\S 1^{\circ}$ A lei estabelecerá o estatuto jurídico da empresa pública, da sociedade de economia mista e de suas subsidiárias que explorem atividade econômica de produção ou comercialização de bens ou de prestação de serviços, dispondo sobre:

I - sua função social e formas de fiscalização pelo Estado e pela sociedade;

II - a sujeição ao regime jurídico próprio das empresas privadas, inclusive quanto aos direitos e obrigações civis, comerciais, trabalhistas e tributários;

III - licitação e contratação de obras, serviços, compras e alienações, observados os princípios da administração pública;

IV - a constituição e o funcionamento dos conselhos de administração e fiscal, com a participação de acionistas minoritários;

$\mathrm{V}$ - os mandatos, a avaliação de desempenho e a responsabilidade dos administradores.

$\S 2^{\circ}$ - As empresas públicas e as sociedades de economia mista não poderão gozar de privilégios fiscais não extensivos às do setor privado.

$\S 3^{\circ}$ - A lei regulamentará as relações da empresa pública com o Estado e a sociedade.

$\S 4^{\circ}$ - A lei reprimirá o abuso do poder econômico que vise à dominação dos mercados, à eliminação da concorrência e ao aumento arbitrário dos lucros.

$\S 5^{\circ}$ - A lei, sem prejuízo da responsabilidade individual dos dirigentes da pessoa jurídica, estabelecerá a responsabilidade desta, sujeitando-a às punições compatíveis com sua natureza, nos atos praticados contra a ordem econômica e financeira e contra a economia popular.
} 


\subsection{O Regime das Sociedades de Economia Mista}

As sociedades de economia mista são pessoas jurídicas de direito privado, controladas pelo Poder Público e quase sempre com participação de capitais privados ${ }^{165}$, fazendo parte da Administração Pública Indireta ${ }^{166}$. São utilizadas pelo Estado, em regra, para a exploração de atividades econômicas ${ }^{167}$. Sua criação exige prévia autorização legislativa ${ }^{168}$, seu tipo societário necessariamente será o de sociedade anônima e, por isso, como se viu, seus principais objetivos são o lucro e a concretização do interesse público. Sujeitamse primariamente às normas próprias das sociedades comerciais privadas, com eventuais derrogações provenientes do regime público ${ }^{169}$. Como já se viu, as sociedades de economia mista representam um instrumento de intervenção do Estado no domínio econômico na sua qualidade de Estado-empresário e na modalidade de atuação direta ${ }^{170}$.

Seu surgimento na França foi fruto de uma necessidade decorrente da crise das concessões de serviço público e a sua assunção por parte do Estado, que necessitava do capital privado para cumprir as funções dele exigidas ${ }^{171}$. A ausência de eficiência do Estado levou a criação de um ente que fundia a

\footnotetext{
165 "Uma sociedade de economia mista também pode ser formada apenas por sócios integrantes da órbita estatal. Mas isso não é necessário, já que empreendedores privados podem deter participação societária. (...) O controle da sociedade de economia mista deverá ser mantido com uma entidade estatal'". JUSTEN FILHO, Marçal. op. cit. p. 266.

166 “Administração Indireta do Estado é o conjunto de pessoas administrativas que, vinculadas à respectiva Administração Direta, têm o objetivo de desempenhar as atividades administrativas de forma descentralizadas". CARVALHO FILHO, José dos Santos. op.cit. p. 463.

${ }^{167}$ Podem também exercer, em determinadas hipóteses, serviços públicos. Não é o caso da Petrobrás, por isso não nos prolongaremos nas distinções quanto ao regime jurídico. V. CARVALHO FILHO, José dos Santos. op. cit. p. 500 e JUSTEN FILHO, Marçal. op cit. p. 265..

${ }^{168}$ Constituição Federal, art. 37, XIX: somente por lei específica poderá ser criada autarquia e autorizada a instituição de empresa pública, de sociedade de economia mista e de fundação, cabendo à lei complementar, neste último caso, definir as áreas de sua atuação;

${ }^{169}$ Decreto $n^{\circ}$ 200/67, art. $5^{\circ}$ : Para os fins desta lei, considera-se: (...) III - Sociedade de Economia Mista a entidade dotada de personalidade jurídica de direito privado, criada por lei para a exploração de atividade econômica, sob a forma de sociedade anônima, cujas ações com direito a voto pertençam em sua maioria à União ou a entidade da Administração Indireta.

170 “A intervenção estatal no domínio econômico [em sentido estrito] verifica-se por meio da sociedade de economia mista e da empresa pública, denominadas genericamente de empresas estatais, que constituem os instrumentos utilizados pelo Estado para atuar empresarialmente na economia, ambas tidas como integrantes da Administração indireta do Estado". EIZIRIK, Nelson. A Lei das S/A Comentada, Volume III. São Paulo: Quartier Latin, 2011. p. 292.

${ }^{171}$ Para uma análise histórica do surgimento das sociedades de economia mista v. idem. p. 284.
} 
iniciativa privada com os fins estatais, e é exatamente essa a característica mais marcante das sociedades de economia mista.

A principal das influências do Direito Público na disciplina das sociedades de economia mista reside na necessidade da aplicação dos princípios de Direito Administrativo à sua atuação, afinal, a despeito de seu caráter privado, a sociedade de economia mista permanece sendo um instrumento de atuação estatal $^{172}$. Assim, as atividades econômicas desempenhadas por essas sociedades, diferentemente das sociedades privadas, devem se pautar pelos princípios da legalidade, impessoalidade, moralidade, publicidade e eficiência além de outras determinações implícitas e explícitas no texto constitucional ${ }^{173}$, estando sujeitas, inclusive à fiscalização estatal externa, através do respectivo Tribunal de Contas, por exemplo $^{174}$.

Apesar dos resquícios do regime público, é imprescindível notar que as sociedades de economia mista são eminentemente pessoas de direito privado ${ }^{175}$. A justificativa da sua criação, aliás, é a de possibilitar ao Estado atuar na sua capacidade empresária e comercial. É exatamente por isso que se faz tão necessário preservar sua personalidade jurídica privada. Sem o regime jurídico, ao menos precipuamente, privado, seria inviável ao Poder Público atuar dentro de mercados com a dinâmica privada, que em muito se diferencia da lógica burocrática inerente à atividade estatal típica ${ }^{176}$. Dessa forma, às sociedades de economia mista se aplicam as normas de direito privado, a não ser que haja

\footnotetext{
${ }^{172}$ DI PIETRO, Maria Sylvia. op. cit. p. 386.

${ }^{173}$ Submetem-se, ademais, em matéria orçamentária (art. 165, § $5^{\circ}$ ), endividamento (arts. 163, e 52, VII), prestação de contas (art. 71, II) e contratação de pessoal, dentre outras, a comando da natureza pública.

${ }^{174} \mathrm{O}$ tema era alvo de grande controvérsia, o atual entendimento foi firmado no julgamento mandado de segurança ${ }^{\circ} 25.902$ (STF, MS 20.902-5/DF, DJ 17 mar. 2006, Rel. Min. Carlos Velloso), onde a antiga orientação do tribunal foi alterada, já que, a despeito de ter capital privado, as sociedades de economia mista ainda pertencem à Administração Indireta, o que permitiria o controle pelo Tribunal de Contas da União, segundo o art. 71, II da Constituição Federal.

175 "Nesse sentido, é clássica a consideração doutrinária de que a sociedade de economia mista é privada quoad extra, isto é, em relação aos terceiros com quem se relaciona e pública quoad intra, ou seja, em suas relações com a entidade pública pela qual foi criada, como instrumento de intervenção no domínio econômico, nas quais se assegura o predomínio da Administração Pública". EIZIRIK, Nelson. op cit. p. 297- 298.

${ }^{176}$ MEIRELLES, Hely Lopes. Direto Administrativo Brasileiro. op. cit., p. 333: "A sociedade de economia mista ostenta a estrutura e funcionamento da empresa particular, porque isto constitui, precisamente, sua própria razão de ser. Nem se compreenderia que se burocratizasse tal sociedade a ponto de emperrar-lhe os movimentos e a flexibilidade mercantil, com os métodos estatais".
} 
alguma derrogação expressa de cunho constitucional (como as já citadas acima) ou legislativo federal (os estados membros têm competência suplementar para legislar quanto ao ponto nos limites da norma geral de competência da União ${ }^{177}$ ), que serão as exceções admitidas somente quando o objetivo for o de mantê-la vinculada ao interesse público.

Quanto ao ponto, é de se destacar as leis $n^{\circ} 6.404 / 76^{178}$ - Lei das S.A. -, que, por regular as sociedades empresarias privadas em geral se aplica para as sociedades de economia mista ${ }^{179}$, e a já mencionada $8.666 / 93^{180}$ - Lei dos Contratos e Licitações Públicas - que proveem as principais normas de âmbito legal para o regime público.

No que diz respeito à Lei das S.A., é importante destacar, a título de exemplo, a submissão das sociedades de economia mista abertas ao mercado como é o caso da maioria delas ${ }^{181}$ - às normas da Comissão de Valores Imobiliários - CVM, órgão regulador e fiscalizador do mercado de capitais. É vetado que se utilize do argumento relativo ao interesse público para o descumprimento das obrigações relativas à sua natureza aberta, como o dever de transparência. Isso remete ao princípio da isonomia, uma vez que não se poderia

177 DA SILVA, José Afonso. Curso de Direito Constitucional Positivo. 34 ed. Malheiros: São Paulo, 2011. p. 503.

${ }^{178}$ Lei $\mathrm{n}^{\circ}$ 6.404/76, art. 235. As sociedades anônimas de economia mista estão sujeitas a esta Lei, sem prejuízo das disposições especiais de lei federal.

$\S 1^{\circ}$ : As companhias abertas de economia mista estão também sujeitas às normas expedidas pela Comissão de Valores Mobiliários.

$\S 2^{\circ}$ : As companhias de que participarem, majoritária ou minoritariamente, as sociedades de economia mista, estão sujeitas ao disposto nesta Lei, sem as exceções previstas neste Capítulo.

179 “Constituindo um dos instrumentos pelos quais o Estado intervém no domínio econômico, a sociedade de economia mista subordina-se, em princípio, ao regime jurídico aplicável às empresas privadas, conforme previsão expressa deste artigo [art. 235, LSA], ao dispor que ela está sujeita às normas da Lei das S.A.”. EIZIRIK, Nelson. op. cit. p. 294.

${ }^{180}$ Lei $^{\circ}{ }^{8} 8.666 / 93$, art. $1^{\circ}$ : Esta Lei estabelece normas gerais sobre licitações e contratos administrativos pertinentes a obras, serviços, inclusive de publicidade, compras, alienações e locações no âmbito dos Poderes da União, dos Estados, do Distrito Federal e dos Municípios.

Parágrafo único: Subordinam-se ao regime desta Lei, além dos órgãos da administração direta, os fundos especiais, as autarquias, as fundações públicas, as empresas públicas, as sociedades de economia mista e demais entidades controladas direta ou indiretamente pela União, Estados, Distrito Federal e Municípios. 181 "Algumas das principais companhias abertas no mercado de capitais brasileiro são sociedades de economia mista. Ainda que, no passado recente, companhias abertas até então de economia mista (...) tenham sido desestatizadas, passando para o controle de particulares, há companhias abertas de economia mista que têm suas ações altamente negociadas na Bolsa de Valores, como, por exemplo, a Petróleo Brasileiro S.A. - Petrobras, o Banco do Brasil S.A. e a Eletrobrás - Centrais Elétricas Brasileiras S.A.”. EIZIRIK, Nelson. op cit. p. 298. 
admitir que a empresa estatal contasse com privilégios em um ambiente de competição.

No mesmo diploma, há uma peculiaridade no regime das sociedades de economia que denuncia seu caráter parcialmente publicístico. Em seu art. $238^{182}$, a lei determina que o acionista controlador desse tipo de sociedade necessariamente o Estado, direta ou indiretamente - tem os mesmos deveres e responsabilidades dos acionistas controladores das outras sociedades anônimas. O legislador, entretanto, achou por bem criar a ressalva concernente à persecução do interesse público. Nesse sentido, portanto, poderia um administrador até certa medida abrir mão da finalidade exclusivamente lucrativa para albergar o interesse público $^{183}$.

Muitas das sociedades de economia mistas atuam em regime de competição com outras empresas privadas. Nesses casos, é indispensável que se analise o seu desempenho de forma isonômica, na esteira do que se destacou no item 1.5, quando se tentou demonstrar a necessidade de tratamento igualitário entre as estatais e a iniciativa privada, de modo a se evitar favorecimentos ilícitos por parte do próprio Estado em relação às suas controladas ${ }^{184}$. Essa foi a filosofia adotada pelo constituinte ao determinar no art. $173, \S 2^{\text {o185 }}$ que os benefícios fiscais concedidos às sociedades de economia mistas devem se estender a seus concorrentes de natureza exclusivamente privada.

\footnotetext{
${ }^{182}$ Lei $\mathrm{n}^{\circ}$ 6.404/76, art. 238: A pessoa jurídica que controla a companhia de economia mista tem os deveres e responsabilidades do acionista controlador (artigos 116 e 117), mas poderá orientar as atividades da companhia de modo a atender ao interesse público que justificou a sua criação.

${ }^{183}$ Há de se registrar uma crítica quanto ao ponto. "Como a sociedade de economia mista constitui o instrumento por meio do qual se conjugam capitais estatais e particulares, seu fundamento reside na viabilidade de desenvolver-se eficazmente atividade de interesse público e ao mesmo tempo produzir lucros que possam ser apropriados por seus acionistas. É essa equação que viabiliza a existência da sociedade. Se não for possível a conciliação da política pública com a produção de resultados econômicos, não se justifica a sua instituição”. EIZIRIK, Nelson. op. cit. p. 313.

184 "Se o Estado se dispuser a atuar num setor em que exista a livre concorrência, será imperioso que norteie a sua atividade pelos preceitos da mais ampla eficiência. Assim se impõe para evitar que o Estado destrua todos os competidores privados. Tal se passaria quando o Estado praticasse preços reduzidos e ruinosos, angariando clientela à custa de seu próprio prejuízo. O resultado seria a inviabilidade econômica dos competidores privados, os quais não disporiam de condições para arcar com prejuízos em termos equivalentes ao que se passa com o Estado". JUSTEN FILHO, Marçal. op. cit. p. 266.

${ }^{185}$ Constituição Federal, art. 173, § $2^{\circ}$ : As empresas públicas e as sociedades de economia mista não poderão gozar de privilégios fiscais não extensivos às do setor privado.
} 
A Lei $n^{\circ}$ 8.666/93, já se viu no capítulo 2, estabelece uma série de obrigações e prerrogativas para além do que se cogita no âmbito privado. Ocorre que, a despeito do texto legal, há considerável divergência acerca da aplicação das disposições lá previstas a esse tipo de sociedade. Isso porque a incidência, ou não, desses privilégios e obrigações deve ser fruto de uma ponderação nem sempre tão óbvia.

\subsection{Cláusulas Exorbitantes e Obrigatoriedade de Licitação nas Sociedades de Economia Mista}

A emenda constitucional $n^{\circ} 19 / 1998$, chamada correntemente de "Reforma Administrativa", entre outras mudanças, deu nova redação ao $\S 1^{\circ}$ do art. 173 e ao art. 22, XXVII ${ }^{186}$ da Constituição Federal. Em relação ao art. 173, a Emenda determinou a instituição de um regime jurídico diferenciado para as sociedades de economia mista e empresas públicas que explorem atividades econômicas. Esse regime deve dispor inclusive sobre licitações e contratações, observados os princípios da Administração Pública. Já em relação ao art. 22, XXVII, que versa sobre a competência da União para legislar sobre normas gerais de licitação e contratação, o constituinte derivado destacou a situação particular das empresas públicas e sociedades de economia mista, referindo-se de forma expressa o art. $173, \S 1^{\circ}$.

Como se vê, a lógica estabelecida pelo constituinte era a de que o legislador originário, levando em conta as características peculiares das sociedades de economia mista e empresas públicas, criasse um regime contratual específico para elas, que se diferiria, como não poderia deixar de ser, dos contratos administrativos em geral, sobretudo pelo seu caráter empresário privado, resguardando-se, é claro, os princípios da Administração Pública.

\footnotetext{
${ }^{186}$ Constituição Federal, art. 22: Compete privativamente à União legislar sobre: XXVII - normas gerais de licitação e contratação, em todas as modalidades, para as administrações públicas diretas, autárquicas e fundacionais da União, Estados, Distrito Federal e Municípios, obedecido o disposto no art. 37, XXI, e para as empresas públicas e sociedades de economia mista, nos termos do art. $173, \S 1^{\circ}$, III
} 
A tarefa do legislador era a de, em um universo onde as empresas privadas concorrem frequentemente com as estatais ${ }^{187}$, criar um equilíbrio, onde as normas de licitação - que, em função dos valores republicanos, como se viu, deve, sim, ser regra ${ }^{188}$ - sejam consideravelmente mais flexíveis que aquelas previstas para a Administração na sua qualidade não empresária - previstas na Lei n 8.666/93 -, ao mesmo passo que não ensejem competição desleal. Esse regime, entretanto, muito em função da morosidade do poder legislativo brasileiro, não foi, até o momento, criado, não tendo sido editada a lei exigida pelo constituinte.

\subsubsection{Atividades-fim e Atividade-meio}

Da conjectura de omissão legislativa, surgiu um vácuo, que, por sua vez, enseja enormes contendas doutrinárias e até mesmo práticas sobre o tema. Devese aplicar as disposições da Lei $\mathrm{n}^{\circ}$ 8.666/93 indiscriminadamente às sociedades de economia mista? Se não, quais serão os parâmetros para a sua aplicação ou o que será aplicado em seu turno? Na prática, a solução encontrada pela doutrina majoritária $^{189}$ e corroborada pela jurisprudência ${ }^{190}$, ainda que, por vezes,

\footnotetext{
187،Ao longo da década de 90 do último século experimentamos uma disseminação do fenômeno dos serviços públicos prestados em regime de competição (vejam aí os exemplos dos regimes das telecomunicações, da energia elétrica e do setor de portos) e, ainda, a quebra do monopólio do Estado sobre o desempenho de determinadas atividades econômicas (vejam aí os casos de algumas atividades petrolíferas e de alguns serviços bancários). Em síntese, experimentamos a introdução do regime jurídico de competição, seja nos chamados serviços públicos econômicos, seja nas chamadas atividades econômicas em sentido estrito exploradas pelo Estado". SUNDFELD, Carlos Ari e SOUZA, Rodrigo Pangani, op. cit. p. 14.

188 "Não houvesse previsão literal do dever de licitar na Lei Maior, é voz corrente na doutrina que, ainda assim, ele se imporia para toda a Administração. Outros comandos constitucionais trazem implícita a exigência de que as contratações da Administração precisam ser feitas por processos competitivos. É o caso da proclamação do Estado brasileiro como uma República $\left(\mathrm{CF}\right.$, art. $\left.1^{\circ}\right)$, donde se extrai que, nele, o poder emana do povo e todos são iguais perante o organismo estatal, sendo proibido o favorecimento indevido de uns em detrimento de outros". Idem, p. 17.

189 "Os contratos celebrados por empresas estatais, atuando na exploração econômica de seu negócio ou patrimônio, não devem ser considerados contratos administrativos, nos termos da CF, art. $173, \S \S 1^{\circ}$, II, e $2^{\circ}$, não devendo tais entes ser equiparados aos demais que integram a Administração Pública, já que realizam negócios jurídicos sem a supremacia do poder de império. Tal fenômeno decorre, pois, da personalidade jurídica de direito privado das sociedades de economia mista e empresas públicas, impondo regime distinto dos demais entes da Administração Pública. Às empresas estatais é aplicado o regime de direito comum, a que se submetem todas as pessoas jurídicas de direito privado, regulando os atos da vida empresarial. Caso seus contratos contivessem os elementos inerentes ao regime público, estariam ferindo o princípio da isonomia, dado o tratamento desigual que seria dispensado a estas em relação a outras empresas com as quais muitas vezes competem" SOUTO, Marcos Juruena Villela. Direito Administrativo em Debate. Rio de Janeiro: Lumen Juris, 2004, p. 146. Nesse sentido v., CARVALHO FILHO, José dos Santos. op.cit. p. 242 e ss, MELLO, Celso Antônio Bandeira de, op. cit. p. 367 e ss. entre outros.

${ }^{190}$ Confira-se, a título de exemplo, trecho do voto do ex-Ministro do STJ, Teori Zavascki: "É certo que a Constituição submete tais empresas a regime próprio de licitação em seus contratos (CF, art. 173, $\S 1^{\circ}$,
} 
contestada firmemente ${ }^{191}$, é a de diferenciar o tipo de atividade que se pretende contratar. Se tratar-se da atividade fim da empresa, i.e. seu objeto de exploração econômica, logo a Lei ${ }^{\circ}$ 8.666/93 seria inaplicável, - a hipótese se encaixaria na modalidade de contrato privado da Administração - caso, por outro lado, se trate de atividade meio da empresa, i.e. atividade eminentemente administrativa, sem qualquer cunho econômico, seriam inafastáveis as prerrogativas e obrigações constantes no diploma - sendo o negócio jurídico um verdadeiro contrato administrativo.

Assim, diferencia-se atividade fim de atividade meio da empresa a fim de se identificar a aplicabilidade ou não da Lei das Licitações e Contratos Administrativos. No caso de um banco público, por exemplo, comprar computadores (atividade meio) para que se possa, através deles, realizar empréstimos (atividade fim). A eventual compra de computadores se curvaria às disposições da Lei n ${ }^{8}$ 8.666/93, enquanto a realização de empréstimos, não.

Há de se reconhecer, entretanto, que essa solução é absolutamente improvisada e só pode se justificar perante o vácuo legislativo em que nos encontramos. É bem verdade que para a realização da atividade fim de uma sociedade de economia mista ou empresa pública jamais poderia se exigir licitação nos rígidos moldes da Lei $\mathrm{n}^{\circ}$ 8.666/93, sob pena de absoluto desvirtuamento das intenções do legislador ao criar a empresa ${ }^{192}$. Se assim não fosse, nos depararíamos, por exemplo, com aberrações práticas como a

III). Tal exigência é feita também em relação a outras sociedades, até mesmo àquelas controladas indiretamente pelo Estado (Lei 8.666, de 21.06.93, art. $1^{\circ}, \S 1^{\circ}$ ). Todavia, a submissão a regime de licitação não acarreta, só por isso, alteração da natureza do contrato daí decorrente, que não se transforma em contrato administrativo. Seria afrontoso à Constituição (art. 173, §1 $1^{\circ}$, II) afirmar que nesses contratos há a incidência de cláusulas exorbitantes (em relação ao direito privado) ou de garantias e privilégios de direito administrativo e ou a presença do Estado como autoridade. Seria, se assim se entendesse, a completa vulgarização do contrato administrativo" STJ, DJe 25 mai. 2006, REsp 683668 / RS, Rel. Min. Teori Zavascki.

191 Nesse sentido v. DALLARI, Adilson. Licitações nas empresas estatais, in Temas de Direito Administrativo: Estudos em Homenagem ao Professor Paulo Neves de Carvalho, org. Sérgio Mourão Corrêa Lima, Rio de Janeiro: Forense, 2006, p. 1-20 e PESSOA, Robertônio Santos. Administração indireta - Uma reflexão crítica, in Revista Interesse Público n 31:75, Rio de Janeiro: Fórum. 2005, p. 84.

192 "Com efeito, ao intervir no domínio econômico por meio da sociedade de economia mista, o Estado, como se ente privado fosse, abandona suas prerrogativas especiais, descendo do "pedestal público" para atuar com os traços típicos do particular, integrando-se, portanto, ao regime jurídico das leis comerciais" EIZIRIK, Nelson. op. cit. p. 294-295. 
necessidade de licitação toda vez que a FINEP financie algum projeto, ou que o BNDES realize um empréstimo.

Impossível se relevar, porém, a difícil e subjetiva tarefa que muitas vezes é precisar o que configura atividade fim e atividade meio de uma empresa. Essa distinção cria zonas de incerteza consideráveis, que, em muitos casos, criam insegurança jurídica tanto para o administrador público, quanto para a empresa que contrata, muitas vezes inviabilizando eventual negócio. Saber de antemão se em determinado contrato há incidência de cláusulas exorbitantes ou se há a obrigatoriedade de licitação prévia à realização do negócio torna-se imprescindível para qualquer contratante e a ausência dessa certeza será prejudicial para o próprio interesse público, sobretudo quando há competidores privados que não terão esse percalço ${ }^{193}$.

Essa distinção - entre atividade fim e atividade meio - apenas poderá se dar levando-se em conta o caso concreto, onde se verificará se há ou não a necessidade de licitação, por exemplo. Muito em função disso, não raramente se vê críticas a esse parâmetro. No entanto, no atual ordenamento, é a solução que, a nosso ver, mais se compatibiliza com os princípios que regem o tema.

\subsubsection{Aplicação ainda constitucional da Lei $n^{\circ}$ 8.666/93}

A aplicação da Lei 8.666/93 em sua totalidade às atividades meio das empresas públicas e sociedades de economia mista apenas se justifica frente ao vácuo legislativo verificado. Trata-se, no nosso sentir, de uma aplicação

\footnotetext{
${ }^{193}$ “O fundamental não é o contrato isoladamente considerado, mas as atividades e as empresas que praticam essa contratação. As características da estruturação empresarial geram a impossibilidade de aplicar o regime de direito público, porque isso acarretaria a supressão do regime de mercado que dá identidade à contratação ou o desequilíbrio econômico que inviabilizaria a empresa privada. Há outra justificativa, de cunho econômico, para a utilização da Administração Pública de contratações puramente privadas. Trata-se da impossibilidade de satisfazer as suas necessidades, do modo menos oneroso, por meio dos contratos administrativos propriamente ditos. (...) O limite para a inovação administrativa decorre de dois aspectos. Em primeiro lugar, há uma limitação econômica. Há hipóteses em que a aplicação do regime de direito público produziria efeitos extremamente onerosos para a Administração Pública - tão onerosos que haveria um sacrifício dos interesses estatais e o comprometimento dos direitos fundamentais. A Administração é constrangida a recorrer aos contratos de direito privado, porque essa é a única alternativa econômica disponível. Em segundo lugar, há uma limitação jurídica. Certas atividades não comportam a aplicação do regime de direito público, porque isso produziria a desnaturação do mercado privado, da livre concorrência e de outros valores protegidos constitucionalmente". JUSTEN FILHO, Marçal. op. cit. p. 551-552.
} 
progressivamente inconstitucional, ou seja, o emprego da Lei $n^{\circ}$ 8.666/93 às atividades meio das sociedades de economia mista, frente à omissão legislativa, é ainda constitucional ${ }^{194}$. Explica-se. Como se vem de expor, a Constituição Federal, em seu art. $173, \S 1^{\circ}$, exige lei específica para a contratação de empresas públicas e sociedades de economia mista. Aplicar a lei geral, destinada idealmente para os contratos eminentemente administrativos, cujas características em muito se diferem daqueles contratos motivados pela atividade empresária do Estado é inconstitucional, no entanto, como não há lei que o faça, evita-se o vácuo e a insegurança jurídica com a aplicação, ainda que inconstitucional, da Lei $n^{\circ} 8.666 / 93$ às - atividades meio das - sociedades de economia mista.

Tudo isso para justificar a necessidade da criação de uma legislação compreensiva das peculiaridades das sociedades de economia mista que materialize um regime próprio adequado a esse tipo de empresa suis generis. A Constituição Federal, a despeito de determinar a necessidade de regime contratual para todo tipo de contrato celebrado pela Administração, em momento nenhum estabelece que esse regime deve ser único, indistinto para todo tipo de contrato em que faça parte o Estado. Muito pelo contrário, sobretudo após a Emenda Constitucional 19/98, que modificou, como se expôs, o art. 22, XXI, restou evidente a intenção do constituinte derivado de que se crie mais um regime, além do rígido regime da Lei $\mathrm{n}^{\circ} 8.666 / 93$ - voltado para os contratos administrativos em geral - que leve em conta a natureza empresária dessas entidades. Esse regime, já se comentou, adaptaria as particularidades do regime publicístico à natureza privada e empresária dos contratos formulados pelas empresas públicas e sociedades de economia mista ${ }^{195}$.

\footnotetext{
${ }^{194}$ A norma (ou interpretação) ainda constitucional, ou inconstitucionalidade progressiva, é o fenômeno no qual se admite que uma norma inconstitucional tenha efeitos, privilegiando a segurança jurídica ao se evitar o vácuo normativo que resultaria da sua nulidade e, portanto, funcionando como uma forma de apelo ao legislador para que ele edite a norma exigida pelo constituinte. Nesse sentido, v. CLÈVE, Clèmerson Merlin. Fiscalização Abstrata de Constitucionalidade no Direito Brasileiro, 2 ed. São Paulo: Revista dos Tribunais, 2000, p. 260.

${ }^{195}$ V. SUNDFELD, Carlos Ari e SOUZA, Rodrigo Pangani, op. cit. p. 18. Dizem os autores que o regime especial não se trataria de uma anomalia e sim o cumprimento de uma norma constitucional.
} 
Tanto não é inconcebível a criação de um regime diferenciado, que é possível se encontrar no atual ordenamento, mais especificamente na Lei $n^{\circ}$ 12.462/11, chamada de Regime Diferenciado de Contratação - RDC, e na Lei Complementar $\mathrm{n}^{\circ} 123$ - Estatuto Nacional da Microempresa e da Empresa Nacional de Pequeno Porte - precisamente isso. Ambas as leis criam regimes simplificados de contratação para negócios realizados com determinados fins específicos ${ }^{196-197}$. Nada justifica que para esses casos seja viável a medida e para as sociedades de economia mista, instituto de indiscutível relevância econômica e social, reconhecida na própria Constituição Federal, não. A bem da verdade é que é necessária uma pressão política mais eficiente sobre o Poder Legislativo para que exerça a sua função nesse âmbito.

\subsection{Conclusão do Capítulo}

As sociedades de economia mista são instrumentos através dos quais o Estado exerce atividade empresária, atuando de forma direta na economia. De forma atípica, portanto, ele participa do mercado, muitas vezes competindo com particulares. Essa característica peculiar faz com que seja premente um regime a elas específico, atento para sua natureza híbrida, respeitando sua finalidade econômica e reguardando o interesse público. No que diz respeito ao regime

\footnotetext{
${ }^{196}$ Lei $\mathrm{n}^{\circ} 12.462 / 11$, art. $1^{\text {o }}$ : É instituído o Regime Diferenciado de Contratações Públicas (RDC), aplicável exclusivamente às licitações e contratos necessários à realização: I - dos Jogos Olímpicos e Paraolímpicos de 2016, constantes da Carteira de Projetos Olímpicos a ser definida pela Autoridade Pública Olímpica (APO); e II - da Copa das Confederações da Federação Internacional de Futebol Associação - Fifa 2013 e da Copa do Mundo Fifa 2014, definidos pelo Grupo Executivo - Gecopa 2014 do Comitê Gestor instituído para definir, aprovar e supervisionar as ações previstas no Plano Estratégico das Ações do Governo Brasileiro para a realização da Copa do Mundo Fifa 2014 - CGCOPA 2014, restringindo-se, no caso de obras públicas, às constantes da matriz de responsabilidades celebrada entre a União, Estados, Distrito Federal e Municípios; III - de obras de infraestrutura e de contratação de serviços para os aeroportos das capitais dos Estados da Federação distantes até $350 \mathrm{~km}$ (trezentos e cinquenta quilômetros) das cidades sedes dos mundiais referidos nos incisos I e II. IV - das ações integrantes do Programa de Aceleração do Crescimento (PAC) V - das obras e serviços de engenharia no âmbito do Sistema Único de Saúde - SUS. VI - das obras e serviços de engenharia para construção, ampliação e reforma de estabelecimentos penais e unidades de atendimento socioeducativo.

${ }^{197}$ Lei Complementar 123/01, art. $1^{\circ}$ : Esta Lei Complementar estabelece normas gerais relativas ao tratamento diferenciado e favorecido a ser dispensado às microempresas e empresas de pequeno porte no âmbito dos Poderes da União, dos Estados, do Distrito Federal e dos Municípios, especialmente no que se refere: I - à apuração e recolhimento dos impostos e contribuições da União, dos Estados, do Distrito Federal e dos municípios, mediante regime único de arrecadação, inclusive obrigações acessórias; II - ao cumprimento de obrigações trabalhistas e previdenciárias, inclusive obrigações acessórias; III - ao acesso a crédito e ao mercado, inclusive quanto à preferência nas aquisições de bens e serviços pelos Poderes Públicos, à tecnologia, ao associativismo e às regras de inclusão. IV - ao cadastro nacional único de contribuintes a que se refere o inciso IV do parágrafo único do art. 146, in fine, da Constituição Federal.
} 
contratual, mais especificamente, como se viu, é possível verificar inconsistências no regime aplicável às entidades, pois, ao não conferir efetividade ao dispositivo constitucional que exigiu a criação de um regime diferenciado, o Poder Público admite que se dê a essas sociedades o mesmo tratamento rígido conferido à Administração Pública em geral, o que, como foi possível concluir, é um erro.

É nesse contexto que se passa à análise da mais importante dessas sociedades, ao menos no que diz respeito à economia nacional; a Petrobras. Além das dificuldades enumeradas acima - que existem para todas as sociedades de economia mista de forma genérica - a Petrobras, por diversos motivos que serão descritos no capítulo subsequente, enfrenta ainda outras a elas peculiares que merecem ser examinadas. É o que se passa a expor. 


\section{Capítulo 4 - O Caso da Petrobrás: Peculiaridades e o Procedimento Licitatório Simplificado}

A Petrobras atualmente se encontra no centro do debate político nacional, como pode se perceber pelos programas de governo dos candidatos à presidência em todas as eleições dos últimos $12 \operatorname{anos}^{198}$. Não é especialmente complexo o motivo do foco na gerência dessa empresa. O setor petrolífero atualmente representa $11,2 \%$ do Produto Interno Bruto Nacional ${ }^{199}$ e a Petrobras, como principal player desse mercado no país, ostenta a posição de maior empresa brasileira no ranking da revista Forbes, estando, até maio de 2014, entre as 50 empresas mais valiosas do mundo e valendo mais de 86 bilhões de dólares ${ }^{200}$.

Soma-se a isso o fato de ser a Petrobras uma sociedade de economia mista, ou seja, uma sociedade anônima de controle do Estado e participação privada, onde se concilia a obtenção de lucro e o interesse público. Assim, o tratamento conferido a ela pelo governo federal acaba por variar significativamente de acordo com a visão ideológica da situação de o que é interesse público e de o quanto o lucro deve pesar na sua gerência. Deve-se estabelecer, portanto, um limite para a atuação da empresa como um mero instrumento de política pública, bem como se deve impedir de, em nome do lucro, que se desatrelem seus objetivos do bem coletivo.

\footnotetext{
198 Exemplificativamente, confira-se pontos de dois dos principais concorrentes a Presidência da República nas eleições de 2014 que apresentaram seus programas. Entre os pontos principais do programa de Aécio Neves: "Resgate do papel da Petrobrás e sua valorização como instrumento vital da política energética brasileira". Disponível em: http://divulgacand2014.tse.jus.br/divulga-cand2014/proposta/eleicao/2014/idEleicao/143/UE/BR/candidato/280000000085/idarquivo/229?x=140468055 5000280000000085, consultado em 17/10/2014: No programa de Marina Silva: "No que diz respeito às estatais, o novo governo eliminará a prática de usá-las como instrumento de política macroeconômica. Isso muitas vezes gera grandes prejuízos para as empresas, como tem ocorrido com a Petrobras e a Eletrobras. Trata-se de ações correntes, usadas como forma de criar subsídios elevados para setores específicos. Tais iniciativas reduzem a eficiência na alocação de recursos e comprometem o crescimento econômico, entre outras coisas, por causa das incertezas geradas quanto a preços relativos. Assim, equilibraremos os preços praticados por estatais para refletir custos e condições de mercado". Disponível em: http://marinasilva.org.br/programa/\#, consultado em 17/10/2014.

199 Os dados foram extraídos do sítio da Petrobras. Disponível em: http://www.petrobras.com.br/fatos-edados/pre-sal-aumenta-importancia-da-industria-do-petroleo-na-economia.htm $\quad$ consultado em $17 / 10 / 2014$.

200 As informações foram extraídas diretamente do sítio da Forbes: disponível em: http://www.forbes.com/companies/petrobras/, consultado em 17/10/2014.
} 
Por conta disso tudo, se faz premente uma sistematização dos limites da ponderação entre o público e o privado em seus contratos, que, além das dificuldades já citadas para as sociedades de economia mista em geral, encontram ainda outros fatores que devem ser levados em conta. $\mathrm{O}$ fato de ser $\mathrm{O}$ seu produto um fator de importância incomensurável para política energética nacional; a Emenda Constitucional $n^{\circ}$ 09/95 e a consequente flexibilização do monopólio do mercado petrolífero; o decreto $\mathrm{n}^{\circ}$ 2.745/98 e o regime licitatório simplificado da Petrobras; a Lei n ${ }^{\circ} 9.478$ - Lei do Petróleo - e a criação da Agência Nacional do Petróleo - ANP - são alguns dos temas peculiares à empresa que orientarão o presente estudo que visa compreender um pouco melhor a importância do regime conferido a seus contratos.

\subsection{Breve histórico da Petrobras}

Com a descoberta da relevância do petróleo para a produção de energia e, consequentemente para a economia mundial ${ }^{201}$, intensificaram-se os debates referentes à atuação do estado brasileiro na área. O potencial da substância representava fator estratégico essencial ao desenvolvimento econômico nacional, sobretudo no que diz respeito à produção energética. Desse dilema duas correntes de pensamento emergiram; os nacionalistas e os liberais.

Para os primeiros, a indústria do petróleo deveria ser de atuação exclusiva do estado, eis que esse representaria, em última instância e acima de tudo, o interesse público, enquanto o mercado privado representaria interesses particulares, capazes de dar outra finalidade ao petróleo, uma que não atenderia à coletividade. Isso se intensificaria ainda pelo fato de não existirem à época empresas brasileiras financeiramente capazes de investir na área, o que significaria que permitir o mercado privado na indústria petrolífera, seria permitir

\footnotetext{
201 "Por ser uma riqueza distribuída de forma desigual pelo planeta e por ser um recurso não-renovável, transformou-se ele em um mercado de extrema importância política, sendo, inclusive, chamado de outro negro, foi e continua sendo causador de crises governamentais, levando a explícitas, e até mesmo, implícitas guerras, massacres e extermínios. Apenas a título de exemplo, pode-se citar a primeira guerra do Golfo, as diferentes guerras entre os países árabes, inclusive a Guerra Irã-Iraque, a luta pela independência da Chechênia e a Guerra Iraque-Estados Unidos da América”. SADDY, A. Formas de Atuação e Intervenção do Estado Brasileiro na Economia, Rio de Janeiro: Lumen Iuris, 2011. p. 185.
} 
a influência ilimitada de capital estrangeiro em um setor de enorme importância estratégica para o país.

Para os liberais - ou "entreguistas" como eram taxados pela parte adversa -, por outro lado, o investimento privado na área era por demais bem-vindo, até porque seria através dele que a área poderia se desenvolver adequadamente, eis que haveria estímulo para a criação de novas tecnologias mais eficientes capazes de satisfazer as necessidades do país - tanto em termos de energia quanto empregos, mercado de consumo, etc -, enquanto ampliando o potencial econômico da área. Para os defensores dessa corrente, o estado brasileiro sequer contaria com a tecnologia ou potencial de investimento para atuar eficientemente no setor e permitir sua exclusiva atuação seria optar por uma alocação de recursos deficiente.

O embate entre as duas correntes se intensificou no período pós-segunda guerra mundial, quando um anteprojeto de lei foi encaminhado ao congresso determinado a criar o Estatuto do Petróleo, onde, inicialmente se adotava as ideias da corrente liberal, abrindo o mercado de petróleo ao capital estrangeiro. $\mathrm{O}$ documento, entretanto, provocou enorme mobilização popular no sentido de se dar ao estado brasileiro o monopólio da indústria petrolífera. Em decorrência disso, em 3 de outubro de 1953 foi aprovada a Lei $\mathrm{n}^{\circ} 2.004$, criando a Petrobras, empresa destinada a cumprir o monopólio estatal da industria de petróleo estabelecido na mesma lei ${ }^{202}$.

A Petrobras, portanto, foi criada como uma sociedade de economia mista, responsável pelo exercício de todas as atividades referentes à indústria petrolífera de titularidade privativa do estado. Como se vê, prevaleceu a corrente nacionalista à época, perpetuada a noção de que o melhor administrador do petróleo, de acordo com o interesse público, seria o próprio poder estatal, que exerceria essa prerrogativa através da Petrobrás.

\footnotetext{
${ }^{202}$ Para um histórico mais detalhado da criação do monopólio na indústria do petróleo v. MARTINS, Daniela Couto. A regulação da Indústria do Petróleo, São Paulo: Fórum, 2006, p. 13-31.
} 
Após 44 anos de prevalência do modelo monopolista exclusivo da União, foi aprovada pelo congresso nacional a E.C. 09/1995, que, consoante a internacionalização do mercado do petróleo, necessidade de maior dinamismo econômico no setor petrolífero e insuficiência de capital por parte da própria Petrobras e do Estado para serem investidos no desenvolvimento do setor ${ }^{203}$, permitiu o exercício das atividades relacionadas ao petróleo por empresas outras que não a Petrobras, incluindo-se empresas privadas no regime de concessão, partilha ou autorização a depender da atividade ${ }^{204}$.

Desse modo a titularidade da União em relação ao setor petrolífero se mantinha, porém passou-se a permitir, através de contratos de concessão, de partilhas ou autorizações por ela outorgados, que a iniciativa privada explorasse da atividade em regime de competição com a Petrobras. Em função dessa emenda, aprovou-se a Lei 9.478/1997, conhecida como Lei do Petróleo, que regulava os novos dispositivos constitucionais oriundos da emenda constitucional.

A edição dessa lei, somada à E.C. 09/95, inaugurou uma nova fase de política energética brasileira ${ }^{205}$, inviabilizando, segundo os atuais dispositivos constitucionais, a manutenção do monopólio da Petrobras no setor. A Lei do Petróleo foi responsável por diversas inovações em áreas que nunca haviam sido normatizadas no país, incluindo-se aí a criação da já citada ANP, agência responsável pela regulação na área, e do Conselho Nacional de Política Energética. Outra questão relevante trazida pelo diploma, que será desenvolvida

\footnotetext{
203 "Vivenciava-se, nessa época [década de 70], um crescimento econômico jamais visto pelo Brasil. Ocorre que depois da primeira crise petrolífera, de outubro de 1973, sintomas de esgotamento das possibilidades desse crescimento já eram visíveis, e com a intenção de manter tal ritmo, discutiu-se sobre se o melhor era ajustar-se ou buscar financiamento. Infelizmente, o país decidiu endividar-se e esgotar suas fontes criando taxas de inflação crescentes, dívidas interna e externa elevadas, acentuando o desequilíbrio do balanço de pagamento, entre outros. Com a política de intervenção direta na economia, a máquina do Estado cresceu e transformou-se num gigante incontrolável, levando o Estado a um declínio (...)". SADDY, A. op. cit. p. 186.

204 "Em linhas gerais, afirma-se que o monopólio tornou-se 'flexibilizável' porque, embora a propriedade dos recursos do subsolo ainda seja da União Federal, o exercício exclusivo, concedido por mais de quarenta anos a uma empresa estatal, a Petrobras, tornou-se aberto a empresas privadas, através da celebração de contratos de concessão para as atividades upstream; ou por meio de autorização, para as atividades downstream". RIBEIRO, Marilda Rosado de Sá. op. cit. p. 419-420.

${ }^{205}$ MARTINS, Daniela Couto, op. cit. p. 9.
} 
propriamente adiante, é a previsão do seu art. $67^{206}$, que delega para o Presidente a competência para a criação de um regime contratual simplificado específico para a Petrobras.

Com a edição da emenda, passou a ser possível que entidades privadas também explorem aquelas atividades que antes eram de exploração exclusiva da Petrobras. Para restituir o modelo anterior, seria necessária nova emenda, o que contrariaria as tendências no setor, ante a dinâmica tecnológica e econômica da indústria, sendo contrário ao próprio interesse público amarrar o sistema à burocracia estatal $^{207}$. A Petrobras passou a desempenhar novo papel dentro do mercado, agora como competidora.

O processo de flexibilização do monopólio, vale destacar, alinhou-se ao desenvolvimento da concepção de Estado, descrito no capítulo 1. Como se vê, inicialmente, não havia qualquer regulação relativa ao mercado petrolífero, nos moldes do Estado Liberal ${ }^{208}$. Em sequencia, com a ascensão do Estado Social, passou-se para o ente estatal a função de prover as melhores condições sociais possíveis, o que o fez tomar para si diversos campos da economia - no caso do petróleo, inclusive, isso se deu através da criação de um monopólio.

Atualmente, nos vemos em um momento onde se reconheceu que o Estado não tem as ferramentas de, autonomamente, criar as melhores condições de efetividade dos direitos fundamentais, a eficiência passou a ostentar posição mais relevante em reação à morosidade e falta de incentivo da burocracia. Isso tudo levou a uma conjectura - em que se vive presentemente - onde o Estado atua de forma subsidiária, regulando e provendo rumos, notadamente através da

\footnotetext{
${ }^{206}$ Lei no ${ }^{\circ}$ 9.478/97, art. 67: Os contratos celebrados pela PETROBRÁS, para aquisição de bens e serviços, serão precedidos de procedimento licitatório simplificado, a ser definido em decreto do Presidente da República.

${ }^{207}$ Convém registrar que o atual modelo brasileiro em muito se inspirou no modelo norueguês de exploração de petróleo, sobretudo na dupla presença do Estado na indústria, tanto através de uma empresa reguladora, no caso brasileiro a ANP, quanto de uma empresa controlada pelo Estado, no caso a Petrobrás. V. HJORUNGNES, Diana Amendoeira Maciel, Brasil, e os próximos dez anos?, in Novos Rumos do Direito do Petróleo, org. Marilda Rosado de Sá Ribeiro, Rio de Janeiro: Renovar, 2009, p. 125 e ss.

208 "Desde seu descobrimento até 1938, a exploração dessa atividade no Brasil era realizada em um regime de livre iniciativa". SADDY, A. op. cit. p. 185.
} 
atividade da ANP, para que os particulares possam auxiliar na persecução aos direitos fundamentais, cada vez menos através da atuação direta através de empresas estatais $^{209}$. Pode-se concluir que o processo de transformação da indústria do petróleo acompanhou a tendência de um contexto mais abrangente de abertura da economia nacional ${ }^{210}$.

\subsection{O Atual Regime da Petrobras}

O setor petrolífero nacional é composto por diversos segmentos, cuja atividade pode ser definida como exploração, produção, refinamento, processamento, transporte, comercialização, distribuição e revenda de petróleo e seus derivados, gás natural e outros hidrocarbonetos ${ }^{211}$. Após a E.C. $n^{\circ}$ 9/95, já se ressaltou, passou-se a admitir a exploração do mercado por particulares. Essa exploração se daria, em regra, através da realização de contratos de concessão ${ }^{212}$, precedidos por licitação. A ANP, como definiu a Lei do Petróleo que a criou, portanto, passou a ser o órgão responsável pela regulação e atribuição de poderes de exploração desenvolvimento e produção no mercado petrolífero ao particular, personalizando a competência de concedente da União ${ }^{213}$.

A Petrobras, como os outros competidores, passou a se submeter aos procedimentos licitatórios para concessão promovidos pela ANP virtualmente em pé de igualdade com os agentes privados ${ }^{214}$, podendo participar de consórcios. Nesse tipo de contratos, as atividades são realizadas por conta e risco da empresa

\footnotetext{
${ }^{209}$ Quanto ao ponto destaca-se a descrição do desenvolvimento dos modelos de Estado especificamente voltada para o petróleo no Brasil de RIBEIRO, Marilda Rosado de Sá. op. cit. p. 285 e ss.

210 "Sem adentrar nos diferentes critérios de sistematização da intervenção do Estado no domínio econômico, vamos assinalar as transformações estruturais envolvidas na implementação das restrições econômicas no Brasil. A primeira delas foi a extinção de restrições ao capital estrangeiro; a segunda, a flexibilização dos monopólios estatais, no qual se inclui o caso do petróleo. A terceira é a privatização operada no plano infra-constitucional, através da Lei 8.031/90, que instituiu o Programa Nacional de Privatização”. RIBEIRO, Marilda Rosado de Sá. op. cit. p. 286

${ }^{211}$ SADDY, A. op. cit. p. 189.

${ }^{212}$ Como se destacou acima, a caracterização do contrato em questão como concessão é alvo de críticas profundas por parte da doutrina, uma vez que em nada se confunde com a noção clássica administrativista de concessão, tratando-se de um contrato bilateral, não precário, cujo objeto é a exploração de uma atividade econômica e não a prestação de um serviço público. Seja como for, esse foi o termo adotado pela lei. Sobre o tema v. ARAGÃO, Alexandre dos Santos de. op. cit. p. 160.

${ }^{213}$ SADDY, A. op. cit. p. 190.

${ }^{214} \mathrm{O}$ art. 42 da Lei do Petróleo dá à Petrobras a vantagem de, na remota possibilidade de empate, ter a preferência, quando não em consórcio. Lei n 9.478/97, art. 42: Em caso de empate, a licitação será decidida em favor da PETROBRÁS, quando esta concorrer não consorciada com outras empresas.
} 
ou consórcio concessionários, que, caso consiga, de fato, desenvolver adequadamente a atividade exploratória, adquire para si os recursos obtidos a partir de determinado ponto, estabelecido no contrato. Além disso, a Lei do Petróleo regulou a transição entre o regime de monopólio da empresa e o regime de competição através dos artigos $32^{215}$ e $33^{216}$, buscando resguardar os investimentos realizados ao longo dos 45 anos de exclusividade ${ }^{217}$.

A descoberta da camada pré-sal, reserva de petróleo e gás natural situada abaixo da espessa camada de sal em alto mar, onde as previsões davam conta de que existem enormes volumes de petróleo e gás natural disponíveis e cujos riscos exploratórios eram reduzidos, gerou uma mudança na estratégia energética nacional. Isso fez com que o Conselho Nacional de Política Energética editasse resolução que excluísse do regime de concessão geral 41 blocos de exploração referentes principalmente às áreas da Bacia de Campos e de Santos -, que se encaixariam nessa recentemente descoberta fonte exploratória de alto potencial. Em função da sua capacidade de influência econômica sobre a política energética nacional, se decidiu desenvolver esforços para que fosse desenvolvido o melhor modelo possível ${ }^{218}$.

Desse esforço se concluiu por um regime diferenciado daquele de concessão $^{219}$, destinado às reservas habituais; Decidiu-se pela adoção do regime de partilha de produção para a exploração na área do pré-sal. Esse regime, de

\footnotetext{
${ }^{215}$ Lei no 9.478/97, art. 32:A PETROBRÁS terá ratificados seus direitos sobre cada um dos campos que se encontrem em efetiva produção na data de início de vigência desta Lei.

${ }^{216}$ Lei $n^{\circ}$ 9.478/97, art. 33: Nos blocos em que, quando do início da vigência desta Lei, tenha a PETROBRÁS realizado descobertas comerciais ou promovido investimentos na exploração, poderá ela, observada sua capacidade de investir, inclusive por meio de financiamentos, prosseguir nos trabalhos de exploração e desenvolvimento pelo prazo de três anos e, nos casos de êxito, prosseguir nas atividades de produção.

217 "Os princípios adotados nessa seção devem ser comentados, levando-se em consideração aspectos importantes do Direito Brasileiro. O primeiro deles é o reconhecimento dos investimentos que a empresa realizou em 45 anos, sob a égide do regime anterior." RIBEIRO, Marilda Rosado de Sá. op. cit. p. 425.

218 "A estimativa econômica advinda das reservas provocou uma reanálise do regime regulador do setor de petróleo e gás, viando encontrar a melhor estratégia para o futuro energético do país. Diante disso, foi instruída, pelo Governo Federal, uma Comissão Interministerial, com o objetivo de estudar os modelos de diversos países, a situação econômica mundial, as implicações jurídicas das propostas, as prioridades do governo; e, ainda, consideradas as carências e aspirações da sociedade brasileira, d definir qual deles seria o mais adequado para exploração e produção de petróleo e gás natural na nova província". RIBEIRO, Marilda Rosado de Sá. op. cit. p. 440.

${ }^{219} \mathrm{O}$ regime de concessões tradicional era visto pelos países produtores como "juridicamente permissivas e economicamente desequilibradas em favor das IOCs [International Oil Companies]". Idem. p. 487
} 
caráter mais estatizado - em função da potencial relevância da camada para o desenvolvimento nacional -, busca dar ao Estado a propriedade de pelo menos parte do produto obtido ${ }^{220}$ e está disciplinado na Lei $\mathrm{n}^{\mathrm{o}}$ 12.351/10.

Segundo a definição legislativa o regime de partilha de produção significa "regime de exploração e produção de petróleo, de gás natural e de outros hidrocarbonetos fluidos no qual o contratado exerce, por sua conta e risco, as atividades de exploração, avaliação, desenvolvimento e produção e, em caso de descoberta comercial, adquire o direito à apropriação do custo em óleo, do volume da produção correspondente aos royalties devidos, bem como de parcela do excedente em óleo, na proporção, condições e prazos estabelecidos em contrato" 221.

No modelo brasileiro optou-se pela participação da Petrobras como operadora obrigatória em todos os blocos de pré-sal, com participação mínima de 30 por cento nos contratos ${ }^{222}$ em regime de consórcio com a empresa ou grupo de empresas privados que se sagrarem vencedores na licitação realizada pela ANP quando não for a Petrobras a única contratada no procedimento licitatório ${ }^{223}-\mathrm{e}$ pela empresa pública que vai gerir a realização do contrato. Essa empresa estatal, de natureza pública, cuja função seria exclusivamente essa - a de gerir os contratos de partilha de produção ${ }^{224}$ - denomina-se Petróleo Pré-sal S.A. - PPSA e teve a sua criação autorizada pela Lei no $12.304 / 10$.

Diferentemente do que ocorre com os contratos de concessão, a titularidade dos hidrocarbonetos produtos da exploração mediante o regime de partilha de produção é do Estado, que não mais é compensado apenas pelo pagamento de royalties e tributos pelo concessionário. Esse - a empresa

\footnotetext{
${ }^{220}$ Ibidem. p. 486.

${ }^{221}$ Lei $\mathrm{n}^{\circ} 12.351 / 10$, art. $2^{\circ}$, I.

${ }^{222}$ Lei $\mathrm{n}^{\circ} 12.351 / 10$, art. 10, III.

${ }^{223}$ Lei no $12.351 / 10$, art. $\left.8^{\circ}, \mathrm{I}, \mathrm{b}\right)$.

${ }^{224}$ Lei $n^{\circ} 12.304 / 10$, art. $2^{\circ}$ : A PPSA terá por objeto a gestão dos contratos de partilha de produção celebrados pelo Ministério de Minas e Energia e a gestão dos contratos para a comercialização de petróleo, de gás natural e de outros hidrocarbonetos fluidos da União.

Parágrafo único. A PPSA não será responsável pela execução, direta ou indireta, das atividades de exploração, desenvolvimento, produção e comercialização de petróleo, de gás natural e de outros hidrocarbonetos fluidos.
} 
exploradora - receberia, por sua vez, apenas parte das extrações, como remuneração pela sua atividade e pelo risco $\operatorname{assumido~}^{225}$, materializados no cost oil $^{226}$ e no profit oil ${ }^{227}$.

Como se vê, mesmo após a quebra do monopólio conferido à Petrobras, a sua participação no mercado do petróleo permanece sendo de protagonista. Em meio aos novos regimes, surgiu a necessidade da empresa se adaptar rapidamente ao mercado competitivo. E isso foi feito, tanto no sentido estratégico ${ }^{228}$, quanto no jurídico. Explica-se esse segundo aspecto. Como se adiantou, uma das grandes inovações da Lei do Petróleo foi a previsão da criação de um regime contratual mais flexível que permitiria que a empresa tivesse uma dinâmica mais próxima daquela típica da iniciativa privada. A normatização desse regime, que passou a ser chamado de "Procedimento Licitatório Simplificado da Petróleo Brasileiro S.A. - PETROBRÁS", se deu através do Decreto Presidencial no 2.745/98 e trouxe dispositivos sensivelmente mais flexíveis do que aqueles previstos para os contratos administrativos em geral pela Lei no 8.666/93 já desenvolvidos no capítulo 2.

\subsubsection{O Regime Licitatório Simplificado da Petrobras}

O novo regime inaugurado pelo decreto presidencial institucionaliza, finalmente, o regime precipuamente privado para todos os contratos da Petrobras, se assemelhando a estatutos sociais de grandes empresas, cujas previsões se adequam às condições de mercado. Nele as hipóteses de dispensa ${ }^{229}$ e de

\footnotetext{
225 "A União poderá assumir a parcela dos riscos com os recursos do 'fundo específico criado por lei', mas somente quando participar dos investimentos". RIBEIRO, Marilda Rosado de Sá. op, cit. p. 494.

${ }^{226}$ Lei $12.351 / 10$, art. $2^{\circ}$, II: custo em óleo: parcela da produção de petróleo, de gás natural e de outros hidrocarbonetos fluidos, exigível unicamente em caso de descoberta comercial, correspondente aos custos e aos investimentos realizados pelo contratado na execução das atividades de exploração, avaliação, desenvolvimento, produção e desativação das instalaçães, sujeita a limites, prazos e condições estabelecidos em contrato;

${ }^{227}$ Lei $12.351 / 10$, art. $2^{\circ}$, IIII: excedente em óleo: parcela da produção de petróleo, de gás natural e de outros hidrocarbonetos fluidos a ser repartida entre a União e o contratado, segundo critérios definidos em contrato, resultante da diferença entre o volume total da produção e as parcelas relativas ao custo em óleo, aos royalties devidos e, quando exigível, à participação de que trata o art. 43.

228 "Nos anos 1995-2012 ocorreram várias mudanças de organização, podendo ser destacadas suas atividades internacionais, agora não mais limitadas às atividades de exploração e produção, mas abrangendo também o refino e a distribuição de combustíveis". RIBEIRO, Marilda Rosado de Sá. op. cit.

p. 421.
${ }_{229}$ Decreto Presidencial n $2.745 / 98$, item 2.1: A licitação poderá ser dispensada nas seguintes hipóteses:
} 
a) nos casos de guerra, grave perturbação da ordem ou calamidade pública;

b) nos casos de emergência, quando caracterizada a urgência de atendimento de situação que possa ocasionar prejuízo ou comprometer a segurança de pessoas, obras, serviços, equipamentos e outros bens; c) quando não acudirem interessados à licitação anterior, e esta não puder ser repetida sem prejuízo para a PETROBRÁS, mantidas, neste caso, as condições preestabelecidas;

d) quando a operação envolver concessionário de serviço público e o objeto do contrato for pertinente ao da concessão;

e) quando as propostas de licitação anterior tiverem consignado preços manifestamente superiores aos praticados no mercado, ou incompatíveis com os fixados pelos órgãos estatais incumbidos do controle oficial de preços;

f) quando a operação envolver exclusivamente subsidiárias ou controladas da PETROBRÁS, para aquisição de bens ou serviços a preços compatíveis com os praticados no mercado, bem como com pessoas jurídicas de direito público interno, sociedades de economia mista, empresas públicas e fundações ou ainda aquelas sujeitas ao seu controle majoritário, exceto se houver empresas privadas que possam prestar ou fornecer os mesmos bens e serviços, hipótese em que todos ficarão sujeitos a licitação; e quando a operação entre as pessoas antes referidas objetivar o fornecimento de bens ou serviços sujeitos a preço fixo ou tarifa, estipuladas pelo Poder Público;

g) para a compra de materiais, equipamentos ou gêneros padronizados por órgão oficial, quando não for possível estabelecer critério objetivo para o julgamento das propostas;

h) para a aquisição de peças e sobressalentes ao fabricante do equipamento a que se destinam, de forma a manter a garantia técnica vigente do mesmo;

i) na contratação de remanescentes de obra, serviço ou fornecimento, desde que aceitas as mesmas condições do licitante vencedor, inclusive quanto ao preço, devidamente corrigido e mediante ampla consulta a empresas do ramo, participantes ou não da licitação anterior;

j) na contratação de instituições brasileiras, sem fins lucrativos, incumbidas regimental ou estatutariamente da pesquisa, ensino, desenvolvimento institucional, da integração de portadores de deficiência física, ou programas baseados no Estatuto da Criança e do Adolescente (Lei no 8.069, de 13 de Julho de 1990), desde que detenham inquestionável reputação ético-profissional;

k) para aquisição de hortifrufigrangeiros e gêneros perecíveis, bem como de bens e serviços a serem prestados aos navios petroleiros e embarcações, quando em estada eventual de curta duração em portos ou localidades diferentes de suas sedes, por motivo ou movimentação operacional, e para equipes sísmicas terrestres.

${ }^{230}$ Decreto Presidencial no 2.745/98, item 2.3: É inexigível a licitação, quando houver inviabilidade fática ou jurídica de competição, em especial:

a) para a compra de materiais, equipamentos ou gêneros que possam ser fornecidos por produtor, empresa ou representante comercial exclusivo, vedada a preferência de marca;

b) para a contratação de serviços técnicos a seguir enumerados exemplificadamente, de natureza singular, com profissionais ou empresas de notória especialização:

- estudos técnicos, planejamento e projetos básicos ou executivos; - pareceres, perícias e avaliações em geral; - assessorias ou consultorias técnicas e auditorias financeiras; - fiscalização, supervisão ou gerenciamento de obras ou serviços; - patrocínio ou defesa de causas judiciais ou administrativas, em especial os negócios jurídicos atinentes a oportunidades de negócio, financiamentos, patrocínio, e aos demais cujo conteúdo seja regido, predominantemente, por regras de direito privado face as peculiaridades de mercado; - treinamento e aperfeiçoamento de pessoal;

c) para a contratação de profissional de qualquer setor artístico, diretamente ou através de empresário, desde que consagrado pela crítica especializada ou pela opinião pública;

d) para a obtenção de licenciamento de uso de software com o detentor de sua titularidade autoral, sem distribuidores, representantes comerciais, ou com um destes na hipótese de exclusividade, comprovada esta por documento hábil;

e) para a contratação de serviços ou aquisição de bens, em situações atípicas de mercado em que, comprovadamente, a realização do procedimento licitatório não seja hábil a atender ao princípio da economicidade;

f) no caso de transferência de tecnologia, desde que caracterizada a necessidade e essencialidade da tecnologia em aquisição; 
empresa contrate sem licitação em hipótese de competição mercadológica que a justifique.

Imprescindível destacar que, consoante o que diz o texto constitucional, ao afirmar que a atuação da empresa ainda se pautará pelos princípios da Administração Pública, o Decreto não alivia a Petrobras de observar os "princípios da legalidade, da impessoalidade, da moralidade, da publicidade, da igualdade, bem como da vinculação ao instrumento convocatório, da economicidade, do julgamento objetivo e dos que lhes são correlatos $^{231, "} \mathrm{em}$ todos os seus contratos.

Desse modo, procurou-se conciliar a natureza de sociedade de regime precipuamente privado, exploradora de atividade econômica competitiva, com sua característica de entidade da Administração Pública Indireta, através de disposições de caráter eminentemente privado, mas que respeitam minimamente os resquícios publicísticos inarredáveis para uma entidade vinculada ao interesse público, o que, como se expôs no capítulo anterior, é indispensável que se faça em relação a todas as sociedades de economia mista.

Ocorre que o regime licitatório simplificado vem sendo alvo de questionamentos no que diz respeito a sua constitucionalidade, tendo sido alvo de

g) para a compra ou locação de imóvel destinado ao serviço da PETROBRÁS, cujas características de instalação ou localização condicionem a sua escolha;

h) para a formação de parcerias, consórcios e outras formas associativas de natureza contratual, objetivando o desempenho de atividades compreendidas no objeto social da PETROBRÁs;

i) para a celebração de "contratos de aliança", assim considerados aqueles que objetivem a soma de esforços entre empresas, para gerenciamento conjunto de empreendimentos, compreendendo o planejamento, a administração, os serviços de procura, construção civil, montagem, pré-operação, comissionamento e partida de unidades, mediante o estabelecimento de preços "meta" e "teto", para efeito de bônus e penalidades, em função desses preços, dos prazos e do desempenho verificado;

j) para a comercialização de produtos decorrentes da exploração e produção de hidrocarbonetos, gás natural e seus derivados, de produtos de indústrias químicas, para importação, exportação e troca desses produtos, seu transporte, beneficiamento e armazenamento, bem como para a proteção de privilégios industriais e para opeações bancárias e creditícias necessárias à manutenção de participação da PETROBRÁS no mercado;

k) nos casos de competitividade mercadológica, em que a contratação deva ser iminente, por motivo de alteração de programação, desde que comprovadamente não haja tempo hábil para a realização do procedimento licitatório, justificados o preço da contratação e as razões técnicas da alteração de programação;

1) na aquisição de bens e equipamentos destinados à pesquisa e desenvolvimento tecnológico aplicáveis às atividades da PETROBRÁS.

${ }^{231}$ Decreto Presidencial no $2.745 / 98$, item 1.2. 
diversas ações no judiciário, bem como tendo a sua inconstitucionalidade declarada pelo Tribunal de Contas da União - TCU. Essa contenda tem como fundamento principal a (in)constitucionalidade formal do dispositivo que veiculou o regime singular da Petrobras. Isso porque, como se viu, a E.C. 19/98 tornou explícito o que já era evidente, que as empresas estatais não só poderiam, como deveriam dispor de um regime contratual diferenciado daquele destinado à atividade meramente administrativa.

A alegada inconstitucionalidade formal seria resultado da regulamentação do regime licitatório através de decreto e não lei, como, para os críticos do regime, a Constituição exigiria. O tópico tem como ponto nodal a interpretação dos artigos alterados com a referida emenda e a possível inovação normativa configurada pelo decreto $\mathrm{n}^{\mathbf{0}} 2.745 / 98$. Com base na interpretação restritiva, segundo a qual o decreto inova no ordenamento jurídico e violaria, por conseguinte, os arts. 22, XXVII, 37, XXI e 173, §1º, III da Constituição Federal, sendo necessária lei no sentido formal para regular a matéria, o TCU declarou a inconstitucionalidade do decreto e mais fundamentalmente do art. 67 da Lei do Petróleo que possibilitou a delegação ${ }^{232}$, obrigando a Petrobras que se abstivesse de aplica-lo nas suas licitações, o que a forçaria a voltar a submeter-se a Lei $\mathrm{n}^{\mathbf{o}}$ $8.666 / 93$.

A decisão foi prontamente questionada pela Petrobras pela via judicial já que, se mantida a tendência firmada pelo TCU, a empresa - e consequentemente a sociedade como um todo - poderia arcar com enormes prejuízos, tanto pelos contratos já firmados sob a égide do novo regime, quanto pela perda da tão necessária dinâmica mercadológica que finalmente lhe havia sido atribuída. $\mathrm{O}$ Supremo Tribunal Federal, em diversas oportunidades ${ }^{233}$, sempre em caráter liminar, se pronunciou apenas no sentido de que configuraria extrapolação das competências do TCU a declaração de inconstitucionalidades de normas.

\footnotetext{
${ }^{232}$ O entendimento se materializou na Decisão 663/2002 do Tribunal de Contas da União.

${ }^{233}$ O leading case é o STF, DJ 29 mar. 2006, MS 25888, Relator Ministro Gilmar Mendes
} 
A despeito de não compartilhar o ponto de vista do TCU, a respeito da inconstitucionalidade formal da norma, é necessário que se teça alguns comentários acerca da decisão do STF, especificamente no que diz respeito ao fundamento para a concessão das liminares que revogaram as decisões da corte de contas.

O TCU é um órgão não jurisdicional de apoio técnico ao Poder Legislativo, cuja principal competência é o controle externo voltado à observância aos princípios administrativos, notadamente do princípio da eficiência, da legalidade e da moralidade, pela Administração Pública em geral e as entidades a ela vinculadas ${ }^{234}$. Desse modo, ele exerce corretamente a sua função ao fiscalizar a celebração e cumprimento dos contratos pela Petrobras, incluindo-se aí, a devida observância ao princípio da obrigatoriedade de licitação quando cabível ${ }^{235}$.

Na esteira da constitucionalização do Direito Administrativo, que será mais detalhada no capítulo 5 do presente estudo, a legalidade administrativa clássica não mais pode servir como parâmetro exclusivo para qualquer órgão estatal. Desse modo, a fiscalização realizada pelo Tribunal de Contas, até por ter como justificativa a preservação de princípios constitucionais, não pode ficar

\footnotetext{
234 "O Tribunal de Contas situa-se no ordenamento jurídico-constitucional como órgão público especializado e independente que colabora com o Poder Legislativo no exercício do controle da atividade financeira pública, prestando-lhe auxílio técnico. Cuida-se do denominado controle externo que, à luz do art. 70 da Constituição da República de 1988, visa a resguardar a probidade da Administração e a regularidade da guarda e do emprego dos bens, valores e dinheiros públicos, assim como a fidelidade na execução do orçamento". WILLEMAN, Marianna Montebello. O Controle de Licitações e Contratos Administrativos pelos Tribunais de Contas in Revista de Direito da Procuradoria Geral do Estado do Rio de Janeiro, n. 64. Rio de Janeiro: CEJUR, 2009. p. 251.

235 Como já se disse no capítulo 3, após grande controvérsia, firmou-se o entendimento de que as sociedades de economia mista se submetem ao controle externo por parte do tribunal de contas competente.
} 
adstrita a mera análise legal dos atos que controla ${ }^{236}$. O entendimento, aliás, foi sumulado pelo próprio $\mathrm{STF}^{237}$.

Infelizmente, entretanto, a Corte Suprema, para escapar do julgamento de mérito de uma questão deveras complexa, optou por se resguardar por meio de liminares, se utilizando do argumento de que a ampliação do rol de legitimados para deflagrar o controle abstrato de constitucionalidade indicaria para uma alteração da capacidade do Tribunal de Contas, retirando de seu escopo a possibilidade de declaração de inconstitucionalidade ${ }^{238}$. Ora, as mudanças paradigmáticas desde a edição da súmula (1963) de fato se deram, mas sua tendência foi justamente contrária ao que tenta sustentar o Supremo já que i) o múnus constitucional dos Tribunais de Contas apenas se expandiu no atual ordenamento constitucional e $i$ ) a estrita legalidade não se coaduna com o status da Constituição com centro do ordenamento jurídico a que se submetem diretamente todos os órgãos estatais.

\footnotetext{
236“'Assim, os Tribunais de Contas, no exercício de sua atividade finalística de controle externo, vinculamse direta e imediatamente à Constituição e, como resultado, têm o poder-dever de apreciar concretamente a constitucionalidade de leis e atos normativos subjacentes a atos e ajustes submetidos a sua apreciação". WILLEMAN, Marianna Montebello. Controle de Constitucionalidade por Órgãos Não Jurisdicionais: A Interpretação Constitucional fora das Cortes, in Revista da Procuradoria do Estado Do Espírito Santo, v. 12 , n 12,2012 . p. 319.

${ }^{237}$ STF, Súmula $n^{\circ}$ 347/63: O Tribunal de Contas, no exercício de suas atribuições, pode apreciar a constitucionalidade das leis e dos atos do poder público.

${ }^{238}$ Confira-se a linha de argumento utilizada: STF, DJ 29 mar. 2006, MS 25888, Relator Ministro Gilmar Mendes: "Não me impressiona o teor da Súmula n 347 desta Corte, segundo o qual "o Tribunal de Contas, o exercício de suas atribuições, pode apreciar a constitucionalidade das leis e dos atos do Poder Público". A referida regra sumular foi aprovada na Sessão Plenária de 13.12.1963, num contexto constitucional totalmente diferente do atual. Até o advento da Emenda Constitucional $\mathrm{n}^{\circ}$ 16, de 1965, que introduziu em nosso sistema o controle abstrato de normas, admitia-se como legítima a recusa, por parte de órgãos não-jurisdicionais, à aplicação da lei considerada inconstitucional. No entanto, é preciso levar em conta que o texto constitucional de 1988 introduziu uma mudança radical no nosso sistema de controle de constitucionalidade. Em escritos doutrinários, tenho enfatizado que a ampla legitimação conferida ao controle abstrato, com a inevitável possibilidade de se submeter qualquer questão constitucional ao Supremo Tribunal Federal, operou uma mudança substancial no modelo de controle de constitucionalidade até então vigente no Brasil. Parece quase intuitivo que, ao ampliar, de forma significativa, o círculo de entes e órgãos legitimados a provocar o Supremo Tribunal Federal, no processo de controle abstrato de normas, acabou o constituinte por restringir, de maneira radical, a amplitude do controle difuso de constitucionalidade. A amplitude do direito de propositura faz com que até mesmo pleitos tipicamente individuais sejam submetidos ao Supremo Tribunal Federal mediante ação direta de inconstitucionalidade. Assim, o processo de controle abstrato de normas cumpre entre nós uma dupla função: atua tanto como instrumento de defesa da ordem objetiva, quanto como instrumento de defesa de posições subjetivas. Assim, a própria evolução do sistema de controle de constitucionalidade no Brasil, verificada desde então, está a demonstrar a necessidade de se reavaliar a subsistência da Súmula 347 em face da ordem constitucional instaurada com a Constituição de 1988".
} 
Desse modo, é possível se concluir que as decisões liminares que revogaram a decisão do TCU são equivocadas quanto a seu fundamento. Ao mesmo, tempo, entretanto, é possível, a nosso sentir, se defender a constitucionalidade do decreto em questão. Em primeiro lugar, de fato, a Constituição estabelece uma reserva legal para a criação de regimes licitatórios próprios para as empresas estatais. A conclusão não é complexa, uma simples interpretação sistemática provê essa solução. Com efeito, as empresas estatais em geral, como se viu, só podem ser criadas através de lei, o que é pacífico. Se para a criação das empresas é necessário que haja lei, não há como sustentar que a disciplina de seu regime seja feita de forma menos rígida.

Isso não quer dizer, porém, que o decreto é inconstitucional, uma vez que a Lei do Petróleo (lei em sentido estrito), além de delegar ao presidente a competência da criação do regime, estabeleceu, juntamente à própria Constituição Federal, os parâmetros a serem seguidos pelo novo regime ${ }^{239}$, de modo que, na prática, ao nosso sentir, não há verdadeira inovação normativa no diploma questionado, tendo o Presidente agido dentro dos limites da delegação atribuída pela lei, que, por sua vez, foi constitucional ao estabelecer os parâmetros a serem seguidos ${ }^{240}$.

É bem verdade que o tema é complexo, configurando hipótese de zona de incerteza. Por isso mesmo seria necessário que o Supremo se manifestasse de forma apropriada de modo a garantir a segurança jurídica dos contratos que já estão sendo realizados sob égide do regime simplificado, bem como ofertar

\footnotetext{
${ }^{239}$ Os parâmetros basicamente estão ligados à observância aos princípios administrativos, como exige o art. $173, \S 1^{\circ}$, III da Constituição Federal.

${ }^{240}$ A abertura ao Executivo é natural naqueles campos em que, por sua alta complexidade, demandam um corpo técnico bem formado e aparelhado. Nestes casos, o Judiciário deve limitar sua atuação, deixando maior margem de manobra à expertise e a experiência dos órgãos e entidades da Administração. Nesse sentido v. Cf. Gustavo BINENBOJM, Gustavo. op. cit. p. 71: "há inúmeras situações em que os princípios da moralidade, da proteção da confiança legítima e da vedação do enriquecimento sem causa operarão, mediante juízos de ponderação racional, no sentido da relativização do princípio da legalidade, validando atos originariamente ilegais ou pelo menos os seus efeitos pretéritos". O próprio STF já decidiu nesse sentido: STF, DJ 4 abr. 2003, RE 343.446-SC, Rel. Min. Carlos Velloso: "Em certos casos (...) a aplicação da lei, no caso concreto, exige aferição de dados e padrões. Nesses casos, comete ao regulamento essa aferição", e por isso admitiu-se, no caso, o regulamento intra legem, ou delegado, especialmente em razão da complexidade técnica da matéria".
} 
estabilidade àqueles investidores que possam vir a querer contratar com a Petrobras. A atual conjectura, onde os negócios são realizados com base em liminares que podem ser revogadas a qualquer momento, não pode se manter, sendo extremamente prejudicial ao interesse da Petrobras e, por conseguinte, ao interesse público.

\subsection{Conclusão do Capítulo}

A Petrobras é uma sociedade de economia mista, o que, por si só, já configura sua natureza suis generis. Entretanto, mesmo entre as sociedades de economia mista, a Petrobras se diferencia em diversos âmbitos, tanto em relação ao aspecto econômico, quanto ao aspecto histórico e ao aspecto jurídico. Desse modo, e por todas essas características, a empresa deve ser estudada de forma sistemática e interdisciplinar. Para compreender seus institutos absolutamente singulares, é necessário que se estude os motivos que levaram a essa especificidade, dentro do contexto jurídico, econômico, histórico e social ${ }^{241}$.

A criação de um regime singular de contratação é apenas um dos grandes demonstrativos da importância política que tem a empresa, que, dentre todas as sociedades de economia mista, foi a única que teve relevância política o suficiente para romper a morosidade do legislador, mesmo que essa tenha se dado mediante delegação e em meio a um contexto de mudanças inadiáveis.

O esforço que, não exaustivamente, tentou se fazer com os capítulos acima foi o de analisar os motivos e as consequências dessa natureza da Petrobras. É premente que se ressalte, entretanto, que a compreensão dos motivos que nos trouxeram ao atual estado de coisas é apenas o primeiro passo da abordagem adequada que aqui se pretende. $\mathrm{Na}$ realidade, colacionar os institutos, o seu histórico e o seu presente estado, no que diz respeito à utilidade, é apenas metade do caminho.

\footnotetext{
241 "Nesse sentido, o modelo brasileiro deve ser estuado tendo-se em mente não apenas o histórico conceitual, mas a natureza jurídica das sociedades de economia mista e do contexto político da aprovação da Emenda Constitucional n 9/95 e da Lei 9478/97”. RIBEIRO, Marilda Rosado de Sá. op. cit. p. 423.
} 
Nesse afã, passa-se agora à tentativa de reunir todo o arcabouço teórico que aqui se expôs no esforço de, inicialmente, se identificar alguns obstáculos à persecução dos fins a que se destinam essas instituições para que, finalmente, se dê início às teorias que possam vir como soluções. A terceira parte do presente estudo que segue se dedica exatamente a esse esforço, o de dar alguma praticidade às premissas teóricas estabelecidas no restante, buscando movimentar certas discussões com novos enfoques a fim de enriquecer o debate. 


\section{TERCEIRA PARTE}

\section{Capítulo 5 - Proposições}

Chegamos ao ponto onde se procurará reunir todos os conceitos colacionados ao longo do estudo, no esforço de se propor uma concepção adequada do regime contratual da Petrobras. Sinteticamente, é possível descrever as proposições em $i$ ) superação da dicotomia rígida entre os regimes público e privado; ii) utilização da análise econômica do direito à atuação empresarial do Estado, notadamente à Petrobras e; iv) relação da Petrobras e a instrumentalização de políticas públicas.

Todos esses pontos exigem e desenvolvem as premissas teóricas estabelecidas ao longo dos capítulos anteriores e seu objetivo é provocar uma reflexão compatível com os valores que permeiam o atual sistema jurídico brasileiro, no sentido de se superar algumas concepções tributárias de valores ultrapassados e ao mesmo tempo se manter fiel à prática jurídica interdisciplinar, essencial para a aproximação entre o mundo do direito e o mundo dos fatos.

\subsection{A Superação da Dicotomia Inflexível dos Regimes Público e Privado}

A dicotomia entre o público e o privado foi consolidada no âmago do Estado liberal, onde o individualismo foi elevado a níveis de divindade, o que levou à crença de que o público, sobre qualquer aspecto, era eminentemente negativo. Posteriormente, com a superação do Estado liberal e com o surgimento do Estado do bem-estar social, se verificou um movimento contrário ao ocorrido no modelo anterior. O direito público passou a tomar para si cada vez mais aspectos da vida social, privilegiando sempre o coletivo em detrimento do individual até o momento em que as prestações assumidas pelo Estado se tornaram excessivamente onerosas, ao ponto de se tornarem de impossível cumprimento $^{242}$. Como se vê, a sociedade e o Estado padeciam de uma separação

\footnotetext{
${ }^{242}$ Para um panorama completo do histórico da dicotomia em todos os seus estágios V. BARROSO, Luís Roberto. Curso de Direito Constitucional Contemporâneo. op. cit. p. 80 e ss.
} 
que abalava sua relação chegando à extensão de impossibilitar a compactação dos fins de ambos - que, na prática, deveriam ser os mesmos.

O Estado democrático de direito, permeado pelo constitucionalismo e pela elevação do papel dos direitos fundamentais (aliado à extensão de seu rol), emergiu buscando reduzir esse afastamento, de modo a buscar, da maneira mais eficiente possível, efetivar e tutelar esses exatamente esses direitos fundamentais. Nesse afã, se elevou a Constituição Federal ao posto de feixe normativo do qual todos os imperativos jurídicos emanam, não apenas no que diz respeito às normas binárias propriamente ditas, como na pirâmide normativa concebida por KELSEN e os positivistas ${ }^{243}$, mas também atribuindo-se eficácia aos seus princípios, que passaram igualmente a dotar de normatividade prática, diretiva e programática sob qualquer ação estatal e, até mesmo, privada.

Desse modo, se percebe a constitucionalização não só do direito público, como é mais fácil de conceber, mas também do direito privado. Atualmente o arcabouço principiológico e normativo constitucional é a fonte primordial de ambos os regimes privado e público. Em função disso, podemos perceber um forte movimento teórico de constitucionalização e interdisciplinaridade das matérias antes autônomas. Exemplo dessa transformação é a importância crescente dos estudos de direito civil constitucional, que modificam as concepções clássicas dos princípios de direito privado, como a autonomia da

\footnotetext{
243 'A validade de todo o ordenamento depende, segundo Kelsen, do disposto na 'primeira Constituição', devendo-se, porém, notar que o adjetivo 'primeira' não indica uma precedência cronológica, mas sim uma prioridade lógica. Assim, a Constituição de 1988 seria, segundo os kelsenianos, a 'norma primeira' na ordem da vigência, subordinando-se-lhe toda a legislação anterior, desde, por exemplo, o Código Comercial de 1850 até à mais recente das leis. Saliente-se que, de conformidade com a teoria kelseniana, não cabe ao jurista, enquanto jurista, indagar das causas sociais ou políticas que dão origem a determinado ordenamento jurídico. Este obriga, do ponto de vista jurídico, pelo simples fato de ter vigência e possuir o mínimo de eficácia bastante para assegurar a sua aplicação. Como se vê, a validade jurídica é apreciada de um ponto de vista puramente formal, de tal modo que as regras jurídicas se ordenariam hierárquica e logicamente, como degraus escalonados, a começar pelas normas de menor incidência, como as particulares e as individualizadas, até alcançar as genéricas, dentre as quais se emergem as disposições constitucionais". REALE, Miguel. op. cit. p. 193-194.
} 
vontade e o pacta sunt servanda para concatená-los aos princípios constitucionais, notadamente ao princípio da dignidade da pessoa humana ${ }^{244}$.

Com o mesmo viés, a constitucionalização do direito administrativo já demonstra ter consequências positivas no rompimento com dogmas oriundos de conceitos não mais compatíveis com o atual Estado ${ }^{245}$. A superação do princípio da supremacia do interesse público ${ }^{246}$, o surgimento da teoria dos graus de vinculação que busca substituir a dicotomia entre ato vinculado e ato discricionário $^{247}$, a emergência do princípio da juridicidade em detrimento do princípio da legalidade administrativa clássica ${ }^{248}$ e a revisão do significado e aplicabilidade do poder de polícia $^{249}$ são símbolos dos novos rumos para que

244 "As relações entre o direito constitucional e o direito civil atravessaram, nos últimos dois séculos, três
fases distintas, que vão da indiferença à convivência intensa. (...) A fase atual é marcada pela passagem
da Constituição para o centro do sistema jurídico, de onde passa a atuar como filtro axiológico pelo qual
se deve ler o direito civil". BARROSO, Luís Roberto. Curso de Direito Constitucional Contemporâneo. op. cit. p. 396.

245 "O Direito Administrativo de cunho europeu do século passado e começo do presente, como assim também a doutrina clássica, não admitem que existam tais direitos subjetivos frente ao Estado como poder e nem que o poder seja um Direito subjetivo similar aos particulares; porém a tendência oposta é cada vez mais forte e responde a uma necessidade sócio-política inegável". GORDILLO, Augustin. Princípios Gerais de Direito Público, trad. Marco Aurélio Greco. São Paulo: Revista dos Tribunais, 1977. p. 92.

${ }^{246} \mathrm{O}$ tema, apesar de ainda controverso, é fortemente defendido por diversos autores já citados no item 1.1 , entre eles BINENBOJM, ARAGÃO, SARMENTO, ÁVILA.

${ }^{247}$ A ideia é a de que o paradigma de dicotomia entre o ato vinculado e o ato discricionário, assim como a dicotomia entre o regime contratual privado e regime contratual público é artificial e não condiz com o princípio da razoabilidade. "Ao invés de uma predefinição estática a respeito da controlabilidade judicial dos atos administrativos (como em categorias binárias do tipo ato vinculado versus ato discricionário), impõe-se o estabelecimento de critérios de uma dinâmica distributiva funcionalmente adequada de tarefas e responsabilidades entre Administração e Judiciário, que leve em conta não apenas a programação normativa do ato a ser praticado (...), como também a específica idoneidade (de cada um dos poderes) em virtude da sua estrutura orgânica, legitimação democrática, meios e procedimentos de atuação, preparação técnica etc., para decidir sobre a propriedade e a intensidade da revisão jurisdicional de decisões administrativas, sobretudo das mais complexas e técnicas" BINENBOJM, Gustavo. op. cit. p. 40.

${ }^{248}$ Muito resumidamente, a teoria pode ser resumida da seguinte forma. "A filtragem constitucional do direito administrativo ocorrerá, assim, pela superação do dogma da onipotência da lei administrativa e sua substituição por referências diretas a princípios expressa ou implicitamente consagrados no ordenamento constitucional. Em tempos de atribuição de amplo poder normativo a entidades da Administração Pública e proliferação de autoridades administrativas, sobreleva a importância dos princípios e regras constitucionais na densificação do ambiente decisório do administrador e amenização dos riscos próprios da normatização burocrática". v. idem. p. 38 .

249 "Ela [a noção de poder de polícia] é terrivelmente problemática, por uma infinidade de motivos. O mais grave deles - que modernamente se quis eliminar, com a exclusão da palavra poder, passando-se a referir apenas a polícia administrativa - é seu timbre autoritário. Reconhecer à Administração um poder de polícia parece significar algo além da mera descrição da função de aplicar as leis reguladoras dos direitos, único sentido que a expressão poderia ter no Estado de Direito". SUNDFELD, Carlos Ari. Direito Administrativo Ordenador. op. cit. p. 11. No mesmo sentido: "O poder de polícia é um dos temas do Direito Público que mais está a merecer atualização. Remonta ele a épocas em que a Administração 
caminha o Direito Público. As noções que essas novas teorias combatem são consectários de valores dogmáticos cuja justificativa não mais se compatibiliza com a constitucionalização do direito e a conjectura panorâmica histórica, política e social do Estado em que vivemos ${ }^{250}$.

Por esses motivos, não seria exagero inferir que estamos em um momento de recente quebra de paradigma - a introdução da constitucionalização do direito e todas suas consequências - que exige um ajuste relativo aos conceitos que, a despeito de nos termos acostumado, são oriundos de noções que não mais se justificam $^{251}$. Nesse liame, é possível inserir a dicotomia entre os regimes público e privado nesse contexto, representando um dogma que necessita ser revisitado de modo a ser, no mínimo, flexibilizado. O emprego adequado do conceito de interesse público, o papel central da Constituição Federal e seus princípios no ordenamento jurídico - inclusive no direito privado - e a sofisticação e decorrente complexidade das relações entre Estado e indivíduos, notadamente no âmbito econômico ${ }^{252}$, faz com que seja premente que se atribua uma roupagem mais dinâmica e flexível à dicotomia e às suas repercussões.

Pública possuía uma competência natural e genérica para conformar os direitos individuais a um metafísico interesse público". ARAGÃO, Alexandre dos Santos. op. cit. p. 35.

250 "Não obstante as transformações por que passou o Estado moderno, desde a ascensão do Estado providência até o seu colapso, verificado nas últimas décadas do século XX, assim como a emergência do Estado democrático de Direito, agravaram o descompasso entre as velhas categorias e as reais necessidades e expectativas das sociedades contemporâneas em relação à Administração Pública" BINENBOJM, Gustavo. op. cit. p. 23..

${ }^{251}$ A origem do direito administrativo para os juristas mais modernos se distingue da noção clássica segundo a qual ele surgiu em reação ao regime absolutista como modo de execução dos direcionamentos do poder legislativo. $\mathrm{O}$ direito administrativo, para eles, seria fruto de resquícios autoritários e seus institutos, como o poder de polícia ou a noção de supremacia do interesse público, denunciariam esse viés. V. idem. p. 11.

252 "No passado, os economistas lidavam com questões reconhecidamente econômicas - inflação e desemprego, poupança e investimento, taxas de juros e comércio exterior. Explicava de que maneira os países enriquecem e como o sistema de preços joga com a oferta e a demanda futura da carne de porco e outros bens de mercado. Ultimamente, contudo, muitos economistas abraçaram um projeto mais ambicioso, porque a economia oferece, sustentam eles, não apenas um conjunto de percepções sobre a produção e o consumo de bens materiais, mas também uma ciência de comportamento humano. No cerne dessa ciência está uma ideia simples mas de grande alcance: em todas as esferas da vida, o comportamento humano pode ser explicado partindo-se do princípio de que as pessoas decidem o que fazer sopesando os custos e benefícios das opções à sua frente e escolhendo aquela que acreditam ser capaz de lhes proporcionar maior bem-estar ou que tenha maior utilidade" SANDEL, Michael J. $O$ que $o$ Dinheiro Não Compra: Os limites morais do mercado, 5 ed. trad. Clóvis Marques. Rio de Janeiro: Civilização Brasileira, 2013. p. 49-50. 
Como se expôs analiticamente ao longo do presente trabalho, as diferenças entre os regimes público e privado no âmbito contratual segundo o modelo clássico são, na prática, enormes e quase sempre os parâmetros que definirão qual será o aplicável são obscuros ou firmados em pressuposições incompatíveis com os valores constitucionais - muitas vezes graças à impossibilidade de adequação à velocidade da dinâmica das relações entre os particulares e o próprio Estado $^{253}$.

Desse modo, a análise a ser feita não deve se basear na miopia formalista, onde pequenos aspectos axiomáticos irão definir o caráter publicístico ou privado de dado contrato ${ }^{254}$. A solução mais compatível com o atual estado de coisas gira em torno das ferramentas hermenêuticas constitucionais como o princípio da razoabilidade e a ponderação, que, ao considerar aspectos concretos de cada contrato, poderão prover a resposta mais atenta aos princípios norteadores do Estado democrático de direito ${ }^{255}$.

É bem verdade que esse é um exercício de difícil visualização. É compreensível que assim o seja, uma vez que ainda vivemos sob a sombra dos modelos estatais ultrapassados cujos paradigmas menores são de difícil mutação, ainda que o paradigma principal tenha sido rompido. No entanto, é essencial que haja um esforço nesse sentido - como já há, por exemplo nas novas teorias

\footnotetext{
253 "Aos poucos se tomou consciência de que os contratos administrativos não tinham um caráter tão exorbitante quanto num primeiro momento se tinha pensado. Simultaneamente, por um processo inverso, verificou-se a percepção da necessidade de sujeitar os contratos jurídicos-privados da Administração a determinadas vinculações de direito público. Trata-se, assim, do segundo termo da dicotomia 'desmistificação do contrato administrativo/publicização do contrato jurídico-privado', que vai ter como principal consequência a uniformização do regime jurídico aplicável a todos os contratos da administração pública". ESTORNINHO, Maria João. Réquiem Pelo Contrato Administrativo, Coimbra: Almendina, 1990. p. 151. Apud ARAGÃO, Alexandre dos Santos. op. cit. p. 163.

254 "Assim é que, procurar uma distinção entre as duas figuras contratuais [pública e privada] se apresentou como um dos primeiros problemas teóricos a serem enfrentados (...)”. MOREIRA NETO, Diogo de Figueiredo. Mutações do Direito Administrativo. op. cit.. 2007. p. 412.

${ }^{255}$ Nesse sentido: "El estudio empírico de las relaciones contractuales en el mercado ("socios de mercado") debería encontrar un vínculo entre las nuevas y las clásicas teorías del contrato (y teorías de la justicia, hasta J. Rawls). El mercado, como toda forma de vida social, está estructurado, funcionalizado, conformado normativamente y constituido jurídicamente en el Estado constitucional. En un punto de vista ideal y real se transforma desde el estado de naturaleza al estado de civilización: por ejemplo, a través de los postulados constitucionales materiales y procesales relativos a la justicia y el bien común" HÄBERLE, Peter.Siete tesis para uma teoria constitucional del mercado trad. Miguel Azpitarte Sanchez, in Revista de Derecho Constitucional Europeo, n. 5. Disponível em <http://www.ugr.es/ redce/REDCE5/articulos/01peterhaberle.htm>, acessado em 27 de outubro de 2014.
} 
emergentes citadas acima ${ }^{256}$ - para que possamos estabilizar o presente modelo e tirar proveito de suas repercussões em desapego a conceitos ultrapassados. A tendência lastreada por esse novo paradigma necessariamente aponta por uma maior dinamização, sobretudo no que diz respeito ao regime público fechado ${ }^{257}$.

Ressalte-se, não se prega aqui uma abnegação ao público em consagração ao privado. Muito pelo contrário, a noção que aqui se defende em nada se justifica no individualismo ou em outros ideais libertários. Reconhece-se o retrocesso que isso representaria para a tutela dos direitos fundamentais ${ }^{258}$. É inegável que a existência de contratos precipuamente públicos ainda se justifica, assim como se admite que, em regra, o interesse público ainda merece maior tutela. O que se sustenta, em seu turno, é a ruptura com a dicotomia dogmática de separação rígida entre os interesses estatais e sociais, que, em essência, deveriam dispor de afinidade permanente. A razoabilidade e a máxima efetivação dos direitos fundamentais, notadamente da dignidade da pessoa humana, clamam por um conceito mais dinâmico e menos artificial tendente a exterminar, ou, ao menos, reduzir a separação entre o Estado e a sociedade ${ }^{259}$.

\footnotetext{
256 Nesse esforço no Brasil se destacam, entre muitos outros, no Direito Público ARAGÃO, BINENBOJM, BARROSO, SARMENTO, ÁVILA, MOREIRA NETO e SUNDFELD. No Direito Privado são imprescindíveis as obras de TEPEDINO, BODIN DE MORAES, SCHREIBER, KONDER COMPARATO, entre outros.

257 "Essas vantagens [trazidas pelo regime público fechado à Administração] perderam sentido e estão em vias de desaparecer dos quadros atuais da economia de mercado, demandante de alta competitividade para atrair capitais, tecnologias, mercados e cérebros, levando o Estado a atuar não mais como executor, mas, preferentemente, como formulador político de instrumentos de fomento". MOREIRA NETO, Diogo de Figueiredo. Mutações do Direito Administrativo. op. cit. p. 418. Como se vê o autor aponta exatamente o que se expôs acima, tanto no que diz respeito à ideia de subsidiariedade da atuação estatal, como também em relação ao desenvolvimento da atividade de fomento em consonância com a ascensão do Estado regulador.

258 "A desregulação pode ser bastante prejudicial se utilizada sem cuidado na área da regulação social. Simplesmente desregular, por exemplo, para remover mecanismos regulatórios, ou desmantelar agências que controlam externalidades, desequilíbrios nas condições de barganhar, assimetrias de informação etc. significa que o mercado é livre para novamente produzir externalidades negativas que a regulação tinha por função corrigir" REICH, Norbert. A Crise Regulatória Existe e Pode Ser Resolvida? Trad. Paulo Todescan L. Mattos in Regulação Econômica e Democracia: O debate europeu. coord. Paulo Todescan L. Mattos.São Paulo: Singular, 2006. p. 40.

259 "Devemos ainda ter em mente que a distinção da natureza jurídica pública ou privada dos contratos celebrados pela Administração Pública deve ser bastante relativizada, tanto pelo lado do Direito Público, quanto do próprio Direito Civil. O que importa são os poderes concretamente conferidos pelo ordenamento jurídico à Administração, não uma classificação etérea da natureza do contrato" ARAGÃO, Alexandre Dos Santos de. op. cit. p. 161.
} 
O que se quer dizer, em essência, é que a distinção apriorística de regimes contratuais entre público e privado atenta contra o princípio da razoabilidade e é vestígio de modelos estatais pretéritos, surgindo como um empecilho para a persecução dos fins do Estado democrático de Direito. Representa uma visão maniqueísta e míope incapaz de contemplar todos os aspectos que jogo, exigindo uma reflexão mais compreensiva.

$\mathrm{Na}$ prática, o resultado da adequação que se defende é a utilização de critérios mais dinâmicos e menos rígidos que compatibilizarão a realidade de cada caso aos aspectos correspondentes atingindo a sua máxima funcionalidade. A bem da verdade, a complexidade em que chegou a interação entre o Estado e a economia sequer nos permite identificar com precisão relações como públicas ou privadas, o que apenas comprova a futilidade da dicotomia em foco ${ }^{260}$.

\subsection{A Aplicação da Análise Econômica do Direito à Atuação da Petrobras}

Com o item 1.2 esperou-se demonstrar a intensa relação entre a economia e o direito. No mesmo sentido, seguindo a linha do item anterior, é indispensável a conclusão de que a interdisciplinaridade se faz cada vez mais essencial na compreensão jurídica. Prosseguindo-se com a análise da repercussão da relação entre direito e economia, a conclusão que se alcança é que não se pode conceber um sem o outro. Desta forma, surge a questão relativa a como proceder diante dessa mútua invasão, que muito tem a ver com a ascensão do debate e prática econômica na vida social.

Em resposta a essa indagação surgiu, inicialmente nos países de língua inglesa, espalhando-se depois para a Europa e outros países, o movimento do

\footnotetext{
${ }^{260}$ Tome-se como exemplo as já comentadas concessões realizadas pela ANP para particulares que visam explorar o mercado petrolífero. A tentativa de encaixar seu conceito como sendo uma típica concessão claramente não se mantem, uma vez que é um contrato voltado à exploração econômica de determinada atividade. Por outro lado, não se pode admitir que a ANP não possua nenhuma prerrogativa em relação ao concessionário, já que isso poderia ser prejudicial ao regime de monopólio flexibilizado atual. Dessa contenda, e por conta da dicotomia que se procura desconstruir, a doutrina tradicional encara um paradoxo e para resolvê-lo, faz uso de criação de figuras esdrúxulas que representariam contratos suis generis com um rol de características preconcebidas já determinadas. É evidente que o atual nível de sofisticação da relação entre o público e o privado não mais suporta essa dicotomia artificial.
} 
Law and Economics ${ }^{261}$, que visa, em abstrato, utilizar a ciência econômica como forma de auxílio na experiência jurídica ${ }^{262}$. Faz-se uso, portanto, das premissas da teoria econômica como forma de compreender e desenvolver institutos jurídicos e, assim, prever seus resultados.

É verdade que essa corrente encontra forte resistência, sobretudo por se entender que sua aplicação significaria um apego aos valores liberais. Ocorre que, a despeito de ser uma teoria fortemente ligada, em alguns casos, a doutrinas voltadas exclusivamente a eficiência econômica e destituídas de valores morais, essa crítica não se justifica em sua integridade. Isso porque a análise econômica do direito costuma a ser sustentada por axiomas ideológicos, como a crença no Estado mínimo, mas essa interseção doutrinária não é necessariamente a única forma de se utilizar o law and economics. Muito pelo contrário, o movimento é tão somente um resultado de uma interdisciplinaridade necessária ao estudo jurídico e o seu conteúdo moral irá depender do seu intérprete.

O ponto é simples, não podemos conceber o direito sem tomarmos em conta as consequências econômicas que ele irá ter sobre a sociedade. Ora, para a tutela de qualquer tipo de direito fundamental - inclusive as liberdades individuais negativas ${ }^{263}$ - é necessário que o Estado provenha de recursos, que garantirão sua efetividade. Esses recursos, como é evidente, são escassos e uma otimização da tutela dos direitos fundamentais exige eficiência econômica. Desse modo, ignorar o aspecto econômico do universo jurídico é como construir um prédio sem arquitetos ou engenheiros. Por melhores que sejam as intenções dos

\footnotetext{
${ }^{261}$ Law and Economics significa direito e economia em uma tradução livre, mas é traduzido comumente como análise econômica do direito. "The economic analysis of law is an interdisciplinary subject that brings together two great fields of study and facilitates a greater understanding of both. Economics helps us to perceive law in a new way, one that is extremely useful to lawyers and to anyone interested in issues of public policy". COOTER, Robert e ULEN Thomas. Law \& Economics. 5 ed. Boston: Pearson. 2007. P. 11.

${ }^{262}$ CYRINO, André Rodrigues. op. cit. p. 140.

${ }^{263}$ O ponto é demonstrado por SUNSTEIN e HOLMES. O livro dos autores vai, aliás, mais longe ao dizer que não há sentido em diferenciar direitos negativos de direitos positivos, uma vez que nenhum dos dois representa, na realidade, uma abstenção do Estado, todos exigem, em algum momento ou outro, uma atitude comissiva por parte do Estado, o que deve ser custeado através de impostos. V. SUNSTEIN, Cass R. e HOLMES, Stephen. op. cit.
} 
juristas, provavelmente seus projetos jamais se manterão. Seria um esforço do dever ser em completa dissintonia com a realidade.

\section{Os liberais (ou conservadores ${ }^{264}$ ) costumam se utilizar dessa teoria para} legitimar suas pretensões individualistas de desaparecimento, ou diminuição, da atividade estatal na vida social. Ocorre que, em regra, os mecanismos utilizados para defender essa visão de mundo se dissociam da moral, apenas objetivando a forma mais eficiente, matematicamente falando, de alocação de recursos ${ }^{265}$. Como se disse, essa corrente não representa a integridade da aplicabilidade da análise econômica do direito que é, na verdade, uma técnica imparcial de interpretação jurídica ${ }^{266}$. É possível se atribuir conceitos econômicos na análise jurídica sem, necessariamente, se abnegar de valores morais, mais especificamente da persecução de direitos fundamentais ${ }^{267}$.

\footnotetext{
${ }^{264}$ A alcunha liberal muitas vezes é associada ao liberalismo social, onde se defende políticas voltadas para o desenvolvimento social e proteção das minorias. O liberalismo a que se refere aqui (também chamado de conservadorismo, sobretudo nos Estados Unidos) diz respeito à ideologia econômica, onde costumeiramente se prega o Estado mínimo e uma reaproximação do laizes-faire.

265 "Quando a guerra fria acabou, os mercados e o pensamento pautado pelo mercado passaram a desfrutar de um prestígio sem igual, e muito compreensivelmente. Nenhum outro mecanismo de organização da produção e distribuição de bens tinha se revelado tão bem-sucedido na geração de afluência e prosperidade. Mas, enquanto um número cada vez maior de países em todo o mundo adotava mecanismos de mercado na gestão da economia, algo mais também acontecia. Os valores de mercado passavam a desempenhar um papel cada vez maior na vida social. A economia tornava-se um domínio imperial. Hoje a lógica de compra e venda não se aplica mais apenas a bens materiais: governa crescentemente a vida como um todo. Está na hora de perguntarmos se queremos viver assim (...). A crise financeira não serviu apenas para pôr em dúvida a capacidade dos mercados de gerir os riscos com eficiência. Generalizou também a impressão de que os mercados desvincularam-se da moral e de que de alguma forma precisamos reestabelecer esse vínculo". SANDEL, Michael J. op. cit. p. 11-12.

${ }^{266} \mathrm{Na}$ realidade, essa é apenas uma das correntes de defensores da law and economics. A base da teoria liberal, que foi desenvolvida na Universidade de Chicago, liderada por POSNER, é o teorema de Coase, que "pode ser interpretado como uma proposta de que se conte uma história a partir de outros momentos e não apenas considerando a existência de um fato jurídico relevante. Ele demonstra o esforço do economista de inserir no pensamento jurídico a necessidade de que se imagine um mundo idealizado em que se alcançaria uma solução mais eficiente independentemente do marco legal. Um mundo em que a história econômica representa um prólogo necessário" CYRINO, André Rodrigues. op. cit. p. 147. Por mais que não seja o uso ideal da análise econômica do direito, por ter pouca praticidade e se desassociar de juízos morais, a corrente traz aspectos interessantes para a discussão. Imaginar uma situação ideal, onde o custo de transação é zero, é um bom mecanismo de se considerar aspectos interdisciplinares na tomada de decisão jurídica.

267 "É, portanto, estranho e lamentável que a análise econômica do direito (law and economics) seja frequentemente associada a um conjunto de ideologias conservadoras e, para muitos moralmente condenáveis que não têm conexão intrínseca com a análise econômica de problemas jurídicos". ROSEACKERMAN, Rose. Análise Econômica Progressista do Direito - E o Novo Direito Administrativo trad. Mariana Mota Prado, in Regulação Econômica e Democracia - O Debate Norte-Americano. Org. Paulo Mattos, São Paulo: Editora 34, 2004. p. 243.
} 
Uma das correntes desse movimento, chamada de Escola Reformista, que se utiliza de premissas econômicas menos radicais, se alinha à possibilidade de eventuais intervenções estatais com fim de redistribuição de riquezas, que em última instância, levariam a uma sociedade mais justa. Procura-se prevenir as falhas mercadológicas inerentes à atividade econômica com fins de promoção de igualdade. A corrente sugere uma reanálise na forma de desenvolvimento de políticas públicas, buscando torna-las mais legítimas e eficientes. Trata-se de uma tentativa de criação de mecanismos que auxiliarão o processo decisório que antecederá o aperfeiçoamento das intervenções estatais, tendo em vista a tentativa de prever e corrigir as possíveis falhas mercadológicas delas decorrentes $^{268}$.

Além de sugerir a promoção de redistribuição de riquezas através de intervenções estatais, a corrente se difere das outras escolas de law and economics quanto ao seu objeto central de estudo. Enquanto, por um lado, as escolas tradicionais - incluindo-se, aí, a Escola de Chicago - se pautam substancialmente no controle judicial da atuação da Administração Pública, a Escola Reformista tem como objeto central a tomada de decisão políticoeconômica. Seu objetivo é repensar esse processo decisório de modo a torná-lo eficiente e democraticamente legítimo ${ }^{269}$.

Na medida do possível, os preceitos acima têm praticidade na experiência brasileira, inclusive em relação à Petrobras, instrumento de intervenção estatal. Uma análise econômica deve preceder a atuação da empresa, cujas repercussões socioeconômicas são de grande importância para a persecução dos direitos fundamentais no país. Assim, antes de se permitir que a empresa se imiscua em empreitadas no sentido de satisfazer o interesse público através de políticas públicas, é imprescindível que se aufira quais as consequências que essa atuação

\footnotetext{
268 "O Direito Administrativo deveria tornar-se mais preocupado com o modo como políticas substantivas são feitas e com a revisão dos paradoxos e inconsistências dos processos de escolha coletiva. Apesar de esta mudança já ter começado, ela deve ir muito além. O foco deveria estar menos em se todos os interesses afetados foram ouvidos ou se o Estado está prejudicando indivíduos específicos, e mais nas características estruturais do processo político e de políticas públicas e na avaliação de resultados substantivos em termos de equidade e eficiência”. ROSE-ACKERMAN, Susan. Op. cit. p. 249.

${ }^{269}$ Idem.
} 
terá para o mercado, e consequentemente para a sociedade. O modelo de tomada de decisão deve ser repensado no sentido de se vincular uma interpretação mais expansiva dos resultados da política pública que se quer botar a cabo.

O mercado do petróleo atingiu níveis de sofisticação e importância altíssimos, sobretudo após a descoberta da camada pré-sal. Os agentes nele envolvidos, concorrentes da Petrobras, são algumas das maiores empresas do mundo $^{270}$. Desse modo, para se manter em condições de competir com essas outras empresas (e auferir lucro, o que, como já se viu, deve ser um de seus objetivos centrais) é essencial que se compreenda as consequências econômicas de instrumentalização da empresa para a persecução de fins atrelados a políticas públicas previamente à sua realização, nos moldes do que prega a Escola Reformista $^{271}$. O simples fato de que a empresa tenha como critérios de gestão mais determinantes o auxílio às políticas de governo - e não o lucro - já é em si um fato de significativos impactos para a sua atuação.

A importância da empresa para o país é inegável ${ }^{272}$ e enfraquecer sua capacidade competitiva pode surtir o efeito contrário ao pretendido pela medida de interesse público que se impôs. Essa conclusão é singela, uma vez que qualquer atuação terá invariavelmente consequências sistêmicas que vão para além das repercussões imediatas e de fácil previsibilidade, sendo imprescindível uma investigação mais compreensiva, capaz de se antecipar às possíveis consequências negativas da medida para uma análise de custo-benefício mais esclarecida.

\footnotetext{
${ }^{270}$ Segundo a Forbes, todas as dez maiores empresas do mercado de petróleo estão entre as cinquenta empresas mais valiosas do mundo. Informações disponíveis em: http://www.forbes.com/global2000/\#page:1 sort:0 direction:asc search: filter:Oil\%20\%26\%20Gas\%20 Operations filter:All\%20countries_filter:All\%20states, consultado em: 27 de outubro de 2014.

271 "A análise econômica do direito deveria estar no centro do estudo do moderno Estado do Bem-Estar Social. Hoje, está na periferia. Ao preocupar-se com o common Law e ao assumir uma visão generalizadamente negativa da operação do setor público, os advogados-economistas delegaram as análises do sistema político-econômico para outros. (...) um tratamento mais construtivo é possível e mesmo necessário. Enquanto alguns dos mais inovadores estudiosos do direito administrativo deram a partida, uma reforma muito mais substancial desta área é necessária. Economistas, analistas de políticas públicas e cientistas políticos deveriam colaborar ativamente com advogados em projetos pedagógicos e educacionais. Aa integração deveria ocorrer tanto no nível da alta teoria, em que as estruturas subjacentes do Estado estão em questão, quanto no nível concreto das políticas públicas, em que análises detalhadas e baseadas em fatos são essenciais". ROSE-ACKERMAN, Susan. op. cit. p. 268.

${ }^{272} \mathrm{Cf}$. dados expostos na introdução do capítulo 5 .
} 
Tome-se como exemplo a hipótese de a Petrobras calcular o preço pelo qual venderá a gasolina por ela produzida, não com base no mercado, mas abaixo dele, na tentativa de incentivar o mercado automobilístico, o que levaria ao aquecimento do setor e à criação de empregos e também como forma de conter a inflação. O fim perseguido através da medida claramente, à primeira vista, está compatível com o interesse público.

Ocorre que, se for realizada uma investigação mais sistêmica, é possível que as consequências mediatas desse tipo de atuação sejam prejudiciais à sociedade como um todo. Explica-se. Ao vender seu produto por preço abaixo do valor de mercado, a Petrobras cria um subsídio estatal para ela deficitário. Isso invariavelmente fará, por um lado, com que ela perca força no mercado - de forte competição - por não estar auferindo o lucro que poderia, pondo em cheque a sua eficiência e, por outro, que seus concorrentes privados sejam destruídos em total dissintonia com a livre concorrência por não terem a capacidade de diminuírem o preço da mesma forma ${ }^{273}$. Isso pode significar, em última instância, mais prejuízos do que aqueles benefícios auferidos com o aquecimento do mercado automobilístico.

Há um exemplo ainda mais prático que ilustra as consequências sistêmicas negativas de algumas condutas adotadas pelo governo recentemente. Exatamente em função da excessiva instrumentalização da empresa pelo governo, a agência de classificação de risco de crédito Moody's Investors Service rebaixou o índice de confiança do crédito da Petrobras no mercado. O relatório que gerou a queda demonstra que o governo tem se imiscuído em demasiado na gestão da companhia, o que, evidentemente, prejudica sensivelmente sua rentabilidade, sua capacidade de angariar investimentos e, portanto, sua capacidade de honrar seus compromissos $^{274}$.

\footnotetext{
${ }^{273}$ JUSTEN FILHO, Marçal. op. cit. p. 266.

${ }^{274}$ Confira-se, por oportuno, trecho do relatório: "While government support continues to provide one notch of uplift on the BCA, we note increasing linkages between Petrobras and the sovereign. The government has been playing a larger oversight role in Petrobras' operations, strategic direction and offshore development. We are maintaining a negative outlook on Petrobras' ratings given the probability
} 
A redução do nível de confiança atribuído ao crédito da empresa tem como consequência direta a diminuição de investimentos, que leva, por sua vez, a um menor fluxo de entrada de capital nacional e estrangeiro na economia do país, o que repercute de forma negativa diretamente no valor da moeda brasileira, diminuindo o poder de compra da população e desacelerando o desenvolvimento econômico nacional como um todo. Esse conjunto de resultados - que provavelmente traz mais prejuízos que os benefícios trazidos diretamente pelas políticas públicas que foram concretizadas - só poderia ser previsto através de uma investigação compreensiva realizada previamente à tomada de decisão que levou à vinculação da Petrobras às políticas de governo.

Desse modo, além do aspecto jurídico da medida, é premente que se procure compreender qualquer atuação de cunho estatal se valendo de preceitos micro e macroeconômicos oriundos das ciências econômicas, o que facilitará a eficiência imprescindível para a persecução dos direitos fundamentais. Ressaltese, que, como se verá mais especificamente no próximo item e já se pontuou, não há aqui uma apologia à impossibilidade de vinculação da Petrobras a eventuais diretivas de governo, muito menos a uma eventual privatização da empresa. Quanto ao ponto específico da análise econômica do direito, o que se defende é que se repense estruturalmente o processo decisório que levaria a essa vinculação para que ele se torne mais compreensivo, sob um aspecto interdisciplinar, e seus resultados se tornem mais eficientes.

that the company's leverage may increase further due to lower international oil prices and limited flexibility to reduce cost, with negative impact on margins. In this environment, execution on the company's capital program and achievement of targeted production growth could be negatively impacted. Petrobras' ratings could be downgraded if financial leverage increases and is sustained with debt/EBITDA above $5 \mathrm{x}$ or if production growth falls short of targets. A downgrade of Brazil could also pressure the Petrobras' ratings. We do not see momentum for an upgrade of Petrobras' ratings in the near-to-medium term. In the longer-term it could be upgraded as the company lowers if debt leverage and delivers on rising and profitable production and reserves growth, in conjunction with a higher rating on Brazil's government debt". Disponível em: https://www.moodys.com/research/Moodys-downgrades-Petrobrasratings-to-Baa2--PR 310942, acessado em 27 de novembro de 2014. 


\subsection{A Petrobras Como Sociedade de Economia Mista e Instrumentalização de Políticas Públicas}

O ponto que segue se relaciona com o anterior, uma vez que, sob outro prisma, procura entender os limites da possibilidade de vinculação da Petrobras a políticas públicas. No capítulo 3 se procurou demonstrar a natureza híbrida suis generis das sociedades de economia, que encontra justificativa na fusão entre algum fim que politicamente se considerou interesse público e o lucro. Também se procurou demonstrar, ao descrever a aplicabilidade do princípio da subsidiariedade, que, por se tratar de uma atuação direta do Estado na economia, a estatal representa uma exceção à regra. Demonstração dessa excepcionalidade é a necessidade de lei para a criação desse tipo de sociedade.

O propósito da excepcional criação de uma sociedade de economia mista, e, portanto, o que motivou o legislador a editar a lei que a criou, é, por conseguinte, um fim único que comunga ao mesmo tempo o lucro e o interesse público, em regime de colaboração entre o capital privado e o público ${ }^{275}$. Tem-se, assim, que além dos motivos de cunho econômicos elencados acima, também por desígnio constitucional, não é possível a desvinculação das estatais da persecução do lucro - bem como é inviável que se desliguem completamente dos fins de interesse público. E assim tem que ser, caso contrário não há mais justificativa para que a empresa se mantenha sob esse regime, sendo mais coerente que se valha ou do formato de empresa privada ou de empresa pública, a depender de qual fim se privilegie.

A instrumentalização de sociedade de economia mista para concretização de políticas públicas é um terreno delicado, onde, em muitos casos se prejudica o lucro em prol de outros valores ligados ao bem coletivo. Com efeito, é legítimo que isso aconteça, quando de forma pontual e dentro dos limites da razoabilidade e seus subprincípios a serem aferidos pelas peculiaridades do caso concreto, de modo que o sacrifício realizado não se torne demasiado. O risco, entretanto, se dá

\footnotetext{
275 "Quando houver sócios privados participando da sociedade de economia mista, o regime jurídico será afetado. Quando o quadro societário da sociedade de economia mista for composto também por sócios privados, acentuar-se-á o seu cunho empresarial especulativo". JUSTEN FILHO, Marçal. op. cit. p. 266.
} 
quando esse tipo de conduta estatal passa a ser sistemática e institucionalizada, passando a gestão da empresa a representar mais uma ferramenta de governo que concretamente uma empresa de predominância privada. Nessas situações a conciliação de fins que legitimou e justificou a criação da empresa estatal cessa por completo.

A polêmica ganha contornos ainda mais relevantes quando se discute a Petrobras, empresa que explora atividade econômica, atua em regime de competição e cujas ações são negociadas no mercado. É essencial para o desenvolvimento nacional que a Petrobras continue a figurar entre as grandes empresas do mundo, expandindo cada vez mais seu mercado e as suas formas de atuação $^{276}$. Ocorre que a captura da atuação lucrativa da empresa pelo governo ${ }^{277}$ gera inegáveis e nefastas consequências para a competitividade e eficiência da empresa, o que leva, consequentemente, ao prejuízo do interesse de seus acionistas minoritários, o lucro.

Os fatores citados no item anterior denunciam a crescente dissociação da atuação da estatal com o lucro, motivo pelo qual a empresa foi criada sob o regime de sociedade de economia mista. Sob um aspecto jurídico, essa desvinculação não é sustentável ${ }^{278}$. Evidentemente, por ter natureza híbrida, é natural que eventuais derrogações sejam admitidas no sentido de, em condição de cedência excepcional, se consagrar determinada medida de interesse público em

\footnotetext{
${ }^{276}$ Após a flexibilização do monopólio do mercado petrolífero, a Petrobras iniciou um planejamento de expansão de suas atividades, criando diversas subsidiárias e explorando o mercado em outros países. "Com a abertura do mercado brasileiro de upstream pela Lei do Petróleo, a Petrobras adotou a estratégia de fazer parcerias para a exploração de algumas áreas obtidas no chamado Round Zero, ao mesmo tempo em que buscava, para enfrentar a concorrência, ampliar o seu campo de atuação. Essa estratégia foi mantida e até ampliada ao longo da década posterior à Lei do Petróleo". RIBEIRO, Marilda Rosado de Sá. op. cit. p. 420-421.

${ }^{277} \mathrm{E}$ aí o mais grave, passa-se a haver uma fusão entre o governo e o Estado, cujas instituições necessitam de uma estabilidade que as constantes alternâncias, senão de partidárias, ao menos estratégicas, não podem oferecer. Essa mistura representa um grande risco para os valores democráticos, não devendo o jogo político ter uma influência tão determinante e tendo como alcunha o termo paternalismo. "Em síntese, trata-se da apropriação da coisa pública como se fosse uma possessão privada, passível de uso em benefício próprio ou dos amigos, ou ainda em detrimento dos inimigos. O agente público que se vale da sua posição ou do patrimônio estatal para obter vantagens, praticar ou cobrar favores e prejudicar terceiros, de forma personalista, viola o princípio republicano". BARROSO, Luís Roberto. Curso de Direito Constitucional Contemporâneo. op. cit. p. 89.

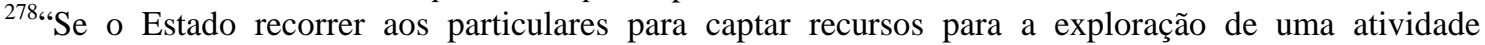
empresarial, acenando com o retorno de lucros, ser-lhe-á vedado ignorar os interesses dos particulares com os quais se associou". JUSTEN FILHO, Marçal. op. cit. p. 266.
} 
sacrifício ao interesse privado, mas sistematizar e institucionalizar a prevalência daquele por este é simplesmente pôr em cheque a própria justificativa de existência da sociedade de economia mista.

Repita-se, é natural que a Petrobras se submeta a diretivas de cunho político, até porque faz parte da Administração Pública Indireta, sendo alvo de supervisão ministerial e fiscalização pelo Poder Legislativo e pelo Tribunal de Contas da União ${ }^{279}$. Diferente disso, porém, é atrelar a sua gestão, que, pela sua natureza preponderantemente privada, deveria ser de cunho empresarial, à instabilidade política típica dos governos. Fazê-lo violaria, inclusive, o direito dos acionistas minoritários, já que "o exercício do direito de controle não pode implicar benefício unilateral e exclusivo ao acionista controlador, mas deve levar em consideração os interesses da companhia e da coletividade de seus acionistas ${ }^{280}$.

Sob o ponto de vista societário, a hipótese de abuso do poder de controle por parte do Estado é absolutamente possível ${ }^{281}$, mesmo nas sociedades de economia mista, se verificar-se a instrumentalização da empresa para fins de cunho clientelísticos, inteiramente dissociados dos fins privados que devem ser resguardados pela sua gestão. $\mathrm{O}$ interesse público deve sempre ser conjugado com a finalidade lucrativa, a impossibilidade de realizar essa compatibilização cria dificuldades sistêmicas, como o abuso de controle pelo Estado e que, apenas após causar muitos prejuízos ${ }^{282}$, denunciará a insustentabilidade do regime atribuído.

\footnotetext{
${ }^{279}$ EIZIRIK, Nelson. op. cit. p. 312.

${ }^{280}$ É claro que, como já se demonstrou, o interesse da companhia não está adstrito ao lucro, incorporando também a noção de interesse público, porém nunca exclusivamente qualquer um dos dois. Assim, continua o autor ressaltando que "o referencial para o exercício regular do poder de controle por parte do Estado é o interesse da companhia no sentido mais amplo, compreendendo o interesse público combinado com a finalidade lucrativa". Idem. p. 314.

281 "A implementação de tais objetivos complementares de Governo, não inseridos no objeto social da sociedade de economia mista, pode constituir abuso do poder de controle, por caracterizar a adoção de políticas ou decisões que não tenham por fim o interesse da companhia e visem a causar prejuízos aos acionistas minoritários e investidores". Ibidem. p. 315.

${ }^{282}$ É impossível, aqui, não fazer referência aos recentes e graves escândalos ligados à administração da Petrobras, onde administradores indicados por motivos exclusivamente políticos pelo governo se locupletaram de suas posições para desviar os recursos da empresa. Isso é apenas uma prova da
} 
A Petrobras atua em um mercado fundamental para o desenvolvimento nacional e, em última instância, para a concretização dos fins do Estado democrático de direito. Nesse liame, é indissociável a sua atuação do interesse público. Foi justamente essa conjectura - que ainda se mantem - que justificou a criação da empresa, de modo que a privatização sustentada por alguns não nos parece ser a estratégia mais adequada no presente momento. Por outro lado, entretanto, é inconcebível, dadas as proporções econômicas que a empresa tomou, a sua reestatização, sendo indispensável para sua subsistência o capital privado que hoje a sustenta.

Com efeito, ainda é possível que se conciliem a atividade da Petrobras como vetor de efetivação do interesse coletivo e a sua finalidade lucrativa. Porém, para tanto, é premente que se desvincule a sua gestão de finalidades partidárias de governo e de políticas públicas sistemáticas cujo objetivo unicamente complementar em nada se aproxima do interesse dos particulares investidores, sob pena de violação aos preceitos que justificaram a sua criação pelo legislador.

problemática por trás da vinculação em questão, que torna mais suscetível a atividade clientelística e, mais grave ainda, corrupta. 


\section{CONCLUSÃO}

"O direito nunca muda de uma vez só: novas construções teóricas erigemse sempre sobre os escombros do passado",283. É com esse ânimo que se inicia a presente conclusão.

Esta monografia se voltou, após a exposição de um arcabouço teórico razoavelmente extenso ${ }^{284}$, a investigar alguns institutos jurídicos sob o prisma do atual estado de coisas de modo a, se adequado, sustentar um rompimento com o paradigma dominante.

Inicialmente, se traçou algumas considerações acerca do conceito de interesse público e as decorrências de suas interpretações, na tentativa de compreender as noções tradicionais a ele atreladas e suas respectivas repercussões. Buscou-se demonstrar a essencialidade desse conceito jurídico indeterminado para a atuação estatal em geral e desconstruir o princípio da supremacia do interesse público por ser consectário lógico de dogmas ultrapassados.

O passo seguinte, relativo à intervenção estatal propriamente dita, configurou uma exposição que se iniciou pela relação entre o Direito e a Economia, passando pelo desenvolvimento teórico do Estado moderno e culminando no exame das diferentes modalidades de intervenção (atividade de fomento, disciplina e atuação direta) e seus mecanismos de interação, a que se aplica sempre em conta o princípio da subsidiariedade.

Os regimes contratuais passaram ao foco, em uma tentativa de se demonstrar as distinções básicas principais entre os regimes público e privado. Se demonstrou que tradicionalmente, os contratos surgiram no ambiente privado, motivados sobretudo pelos princípios da autonomia da vontade e do pacta sunt servanda. O desenvolvimento da capacidade negocial estatal exigiu uma

\footnotetext{
${ }^{283}$ BINENBOJM, Gustavo. op. cit. p. 335.

${ }^{284}$ No sentido de abranger uma grande quantidade de matérias que aparentemente não se relacionavam prima facie.
} 
adaptação do instituto de modo a adequá-lo às peculiaridades inerentes à natureza pública.

Essas adaptações levaram ao que nós concebemos hoje como regime contratual público, onde se observa a presença das cláusulas exorbitantes que se convertem em privilégio da Administração Pública, ao mesmo tempo em que há a obrigatoriedade pela realização de licitação prévia à realização do contrato, como forma de consagração dos princípios administrativos.

Ocorre que, como se passou a demonstrar na sequencia, há institutos no complexo universo jurídico da Administração Pública, cuja natureza não é de fácil percepção, sendo a distinção clássica entre regimes de inviável aplicação. As sociedades de economia mista, frutos de um regime híbrido delicado de conciliação entre lucro e interesse público, enfrentam polêmicas de enorme complexidade quando da sua atuação. Isso porque, ao mesmo tempo em que, em muitos casos, frequentam ambientes competitivos eminentemente privados, também devem prezar pela persecução do fim que justificou a sua criação, que, por sua vez, necessariamente deve ser vinculado ao interesse coletivo.

As dificuldades enfrentadas pelas sociedades de economia mista em geral se exacerbam no que diz respeito à maior delas, um dos objetos de estudo da presente monografia. A Petrobras, maior empresa brasileira, se submete ao regime de sociedade de economia mista. No entanto, muito em função da sua importância econômica e de seu histórico de empresa monopolista, possui tratamento singularizado no que diz respeito a seu regime contratual, se submetendo a um regime licitatório flexível mais condizente com a sua natureza privada e, mais importantemente, competitiva.

A despeito das contendas doutrinárias e judiciais acerca da constitucionalidade desse regime, se impunha que houvesse, como se buscou através do decreto que o criou, uma flexibilização no que diz respeito ao regime contratual constante na Lei de Licitações e Contratos Administrativos. A Petrobras jamais triunfaria no mercado competitivo sem esse ajuste, que, diga-se, 
veio em momento crucial para a empresa dentro do cenário econômico nacional e internacional.

Os novos rumos a que se encaminha o mercado do petróleo, notadamente a Petrobras, são ainda mais relevantes em função da descoberta do pré-sal que tornou ainda mais complexo o já sofisticado setor petrolífero. Desse modo, e por todo o exposto, foi possível se alcançar algumas proposições que se espera sirvam para auxiliar a adequação dos institutos em comento aos princípios e valores que atualmente ditam os paradigmas que deveriam conformar a área, mas que, por apego a valores passados, se mantém obscuros.

A primeira dessas proposições, como se viu, segue a mesma linha da superação do princípio da supremacia do interesse público, haja vista que busca combater uma dicotomia tradicional do direito administrativo com origens em noções oriundas de diretivas superadas e incompatíveis com o Estado democrático de direito, baseando-se por vezes, em noções autoritárias ou em condutas que já se provaram ineficientes por parte da Administração Pública. A dicotomia entre os regimes público e privado representa uma noção formalista e míope que retira do administrador e do particular a possibilidade de se adequar, nos limites da razoabilidade, à real conjectura contratual em jogo. Com isso, espera-se seja superada essa dicotomia artificial e cuja concretização é infrutífera.

A segunda delas diz respeito à aplicação da análise econômica do direito mais especificamente da Escola Reformista - ao processo de tomada de decisão política na atuação da empresa como instrumento do Governo/Estado. Procurouse demonstrar, sob um aspecto econômico interdisciplinar amplo, que, em relação à persecução de tutela de direitos fundamentais, é necessário se realizar uma investigação prévia de custo-benefício - não apenas financeiro, mas sistêmico - no desenvolvimento de políticas públicas, de modo a otimizar a alocação de recursos, tendo como norte a distribuição eficiente de riqueza, que, 
em última instância, levará a uma atuação estatal sensível para suas próprias limitações e mais suscetível de alcançar seus fins democráticos.

A última delas, que tem ligação com a anterior, diz respeito à relação entre a Petrobras e a concretização de políticas públicas, sob um aspecto jurídico. Tanto quanto ao aspecto do direito administrativo, no que diz respeito à natureza precipuamente privada das sociedades de economia mista, quanto no aspecto societário, que diz respeito sobre o abuso do poder de controle por parte do Estado, é impossível se conceber a legitimidade na instrumentalização sistemática da Petrobras para concretização de políticas públicas em detrimento absoluto do lucro, sob pena de que se passe a inexistir a justificativa que levou a sua criação. A despeito de se admitir derrogações eventuais relativas à finalidade coletiva da sociedade, seu caráter privado, competitivo e, por conseguinte, lucrativo não pode ser, como tem sido, descartado levianamente.

Retomando a abertura do presente capítulo, não se espera que as alterações sugeridas se deem de forma repentina, até porque o direito é uma ciência usualmente tradicionalista e não costuma se valer desse tipo de transformação sem uma crise paradigmática abrupta. No entanto, para que essas adaptações se materializem, é imprescindível que já esteja inaugurado e amadurecido o debate doutrinário, que irá fertilizar o campo no qual as metamorfoses necessárias se darão. 


\section{Bibliografia}

ALESSI, Renato. Principi di diritto amministrativo, v. I. Milão: A. Giuffrè, 1974

ALEXY, Robert. Theorie der Grundrechte. 2 ed. Frankfurt am Main: Suhrkamp, 1994.

AMARAL, Flávio Garcia, Licitações e Contratos Administrativos (Casos e Polêmicas). Rio de Janeiro: Lumen Iuris. 2007.

ARAGÃO, Alexandre Santos de. Agências Reguladoras e a Evolução do Direito Administrativo Econômico, $3^{\mathrm{a}}$ ed. Rio de Janeiro: Forense, 2013.

. O Princípio da Eficiência. Revista Eletrônica de Direito Administrativo

Econômico n 4, Salvador: Instituto de Direito Público da Bahia, 2006.

ÁVILA, Humberto Bergmann. Repensando o "Princípio da supremacia do interesse público sobre o particular”, in Interesses Públicos versus Interesses Privados: Desconstruindo o Princípio de Supremacia do Interesse Público org. Daniel Sarmento, Rio de Janeiro: Lumen Iuris. p 171-216. 2005.

BARCELlOS, Ana Paula. Ponderação e Racionalidade. Rio de Janeiro: Renovar, 2005.

BARROSO, Luís Roberto. A Ordem Econômica Constitucional e os Limites à Atuação Estatal no Controle de Preços, in Revista de Direito da Associação de Procuradores do Novo Estado do Rio de Janeiro:Direito da Regulação, v. XI, coord. Alexandre dos Santos de Aragão, Rio de Janeiro: Lumen Iuris, 2002.

Curso de Direito Constitucional Contemporâneo. 4 ed. Rio de Janeiro: Saraiva, 2013.

BINENBOJM, Gustavo. Uma Teoria de Direito Administrativo. $3^{\mathrm{a}}$ ed. Rio de Janeiro: Renovar, 2014.

BOBBIO, Norberto. Dalla Struttura Alla Funzione. Edizioni di Comunitá: Milão, 1977. 
BRITTO, Carlos Ayres. O Perfil Constitucional da Licitação. Curitiba: ZNT, 1997.

CARVALHO FILHO, José dos Santos. Manual de Direito Administrativo, 27 ed. São Paulo: Atlas, 2014.

CLÈVE, Clèmerson Merlin. Fiscalização Abstrata de Constitucionalidade no Direito Brasileiro, 2 ed. São Paulo: Revista dos Tribunais, 2000.

COOTER, Robert e ULEN Thomas. Law \& Economics. 5 ed. Boston: Pearson. 2007.

CYRINO, André Rodrigues. Direito Constitucional Regulatório: Elementos para uma Interpretação Institucionalmente adequada da Constituição Econômica Brasileira. Rio de Janeiro: Renovar, 2010.

DA SILVA, José Afonso. Curso de Direito Constitucional Positivo. 34 ed. Malheiros: São Paulo, 2011.

DALLARI, Adilson Abreu. Aspectos jurídicos da Licitação, $4^{\mathrm{a}}$ ed. São Paulo: Saraiva, 1997.

Licitações nas empresas estatais, in Temas de Direito Administrativo: Estudos em Homenagem ao Professor Paulo Neves de Carvalho, org. Sérgio Mourão Corrêa Lima, Rio de Janeiro: Forense, 2006

DALLARI, Dalmo de Abreu. Elementos da Teoria Geral do Estado, 23ª ed. São Paulo: Saraiva, 2002.

DE ENTERRÍA, Eduardo Garcia e FERNÁNDEZ, Tomás-Ramon. Curso de Derecho Administrativo vol. I, $5^{\text {a }}$ ed. Madri: Civitas, 1998.

. Curso de Derecho Administrativo vol. II, $5^{\text {a }}$ ed. Madri: Civitas, 1998.

DEVOLVÉ, Pierre. Droit Public de l'Economie. Paris: Précis, 1998.

DI PIETRO, Maria Sylvia Zanella. Direito Administrativo, $14^{\mathrm{a}}$ ed. São Paulo: Atlas, 2012. 
DWORKIN, Ronald. Taking Rights Seriously, Cambridge: Harvard University Press, 1977.

EIZIRIK, Nelson. A Lei das S/A Comentada, Volume III. São Paulo: Quartier Latin, 2011.

ESTORNINHO, Maria João. Réquiem Pelo Contrato Administrativo, Coimbra: Almendina, 1990.

GOMES, Orlando. Contratos, $17^{\mathrm{a}}$ ed. Rio de Janeiro: Forense, 1996.

GORDILlO, Augustin. Princípios Gerais de Direito Público (trad. Marco Aurélio Greco). São Paulo: Revista dos Tribunais, 1977.

GRAU, Eros Roberto. A Ordem Econômica na Constituição de 1988. $5^{\mathrm{a}}$ ed. Malheiros: São Paulo, 2000.

. O Direito Posto e o Direito Pressuposto. São Paulo, Malheiros, 2005.

HÄBERLE, Peter. Siete tesis para uma teoria constitucional del mercado trad. Miguel Azpitarte Sanchez, in Revista de Derecho Constitucional Europeo, n. 5. Disponível em 〈http://www.ugr.es/ redce/REDCE5/articulos/01peterhaberle.htm>, acessado em 27 de outubro de 2014.

HJORUNGNES, Diana Amendoeira Maciel, Brasil, e os próximos dez anos?, in Novos Rumos do Direito do Petróleo, org. Marilda Rosado de Sá Ribeiro, Rio de Janeiro: Renovar, 2009.

JUSTEN FILHO, Marçal. Curso de Direito Administrativo, $8^{\mathrm{a}}$ ed. Belo Horizonte: Editora Fórum, 2012.

MARTINS, Daniela Couto. A regulação da Indústria do Petróleo, São Paulo: Fórum, 2006.

MELLO, Celso Antônio Bandeira de. Curso de Direito Administrativo, $30^{\mathrm{a}}$ ed. São Paulo: Malheiros, 2013.

MEIRELLES, Hely Lopes. Direito administrativo brasileiro, $18^{a}$ ed. São Paulo: Malheiros, 1993. 
. Licitação e o Contrato Administrativo, 9ª ed., São Paulo: RT, 1990.

MENDONÇA, José Vicente Santos de. Uma teoria do Fomento Público: Critérios em Prol de um Fomento Público Democrático, Eficiente e NãoPaternalista, in Revista de Direito da Procuradoria Geral, v. 65, CEJUR:Rio de Janeiro, 2010.

MONCADA, Luís Cabral de Oliveira. Direito Económico, 4a ed. Coimbra: Coimbra Editora, 2003.

MOREIRA, José Carlos Barbosa. Regras de experiência e conceitos juridicamente indeterminados, in Temas de direito processual, $2^{\text {a }}$ série. São Paulo: Saraiva, 1988.

MOREIRA NETO, Diogo de Figueiredo. Curso de Direito Administrativo. $14^{\mathrm{a}}$ ed. Rio de Janeiro: Forense. 2005.

- Quatro Paradigmas do Direito Administrativo pós-moderno: Legitimidade, Finalidade, Eficiência e Resultados. Belo Horizonte: Fórum, 2008.

MOREIRA NETO, Diogo de Figueiredo. Mutações do Direito Administrativo. $3^{\mathrm{a}}$ ed. Rio de Janeiro: Renovar. 2007.

ORTIZ, Gaspar Ariño. Princípios de Derecho Público Económico, Granada: Comares. 1999.

OSÓRIO, Fábio Medina. Existe uma supremacia do Interesse Público sobre o privado no direito Administrativo brasileiro? Revista de Direito Administrativo, Rio de Janeiro. v. 220, p. 69-107, 2000.

PESSOA, Robertônio Santos. Administração indireta - Uma reflexão crítica, in Revista Interesse Público n 31:75, Rio de Janeiro: Fórum. 2005.

POSNER, Richard. The Constitution as an Economic Document, in George Washington Law Review, n 56, 1987. 
REICH, Norbert. A Crise Regulatória Existe e Pode Ser Resolvida? Trad. Paulo Todescan L. Mattos in Regulação Econômica e Democracia: O debate europeu. coord. Paulo Todescan L. Mattos.São Paulo: Singular, 2006.

RIBEIRO, Marilda Rosado de Sá. Direito do Petróleo. $3^{\mathrm{a}}$ ed. Rio de Janeiro: Renovar. 2014.

ROSE-ACKERMAN, Rose. Análise Econômica Progressista do Direito - E o Novo Direito Administrativo trad. Mariana Mota Prado, in Regulação Econômica e Democracia - O Debate Norte-Americano. Org. Paulo Mattos, São Paulo: Editora 34, 2004.

SADDY, A. Formas de Atuação e Intervenção do Estado Brasileiro na Economia. Rio de Janeiro: Lumen Iuris, 2011.

SANDEL, Michael J. O que o Dinheiro Não Compra: Os limites morais do mercado, 5 ed. trad. Clóvis Marques. Rio de Janeiro: Civilização Brasileira, 2013.

SARMENTO, Daniel. Interesses públicos "versus" interesses privados na Perspectiva da Teoria e da Filosofia Constitucional in Interesses Públicos versus Interesses Privados: Desconstruindo o Princípio de Supremacia do Interesse Público org. Daniel Sarmento, Rio de Janeiro: Lumen Iuris. p. 23-116, 2005.

SOUTO, Marcos Juruena Vilena. Direito Administrativo Contratual. Rio de Janeiro: Lumen Juris, 2004.

SUNDFELD, Carlos Ari. Fundamentos de Direito Público, $4^{\mathrm{a}}$ ed. São Paulo: Malheiros, 2013.

Direito Administrativo Ordenador, 3 ed. São Paulo: Malheiros, 1997.

SUNDFELD, Carlos Ari e SOUZA, Rodrigo Pangani, Licitações nas Estatais: Levando a Natureza Empresarial a Sério, in Revista de Direito Administrativo, vol. 245. Rio de Janeiro: Atlas, 2007.

SUNSTEIN, Cass R. O Constitucionalismo após o The New Deal trad. Jean Paul Cabral Veiga da Rocha in Regulação Econômica e Democracia - O Debate Norte-Americano. Org. Paulo Mattos, São Paulo: Editora 34, 2004. 
The Partial Constitution. Cambridge: Harvard University Press, 1993.

SUNSTEIN, Cass e HOLMES, Stephen. The costs of Rights: Why liberty depends on taxes, New York: W. W. Norton \& Co., 1999.

SUNSTEIN, Cass R. e THALER, Richard H. Nudge: Improving decisions about health, wealth and happiness, Chicago: Penguin books, 2009.

WEBER, Max. Economia e Sociedade, Vol. II. trad. Regis Barbosa. São Paulo: UNB. 2011.

WILlEMAN, Marianna Montebello. Controle de Constitucionalidade por Órgãos Não Jurisdicionais: A Interpretação Constitucional fora das Cortes, in Revista da Procuradoria do Estado Do Espírito Santo, v. 12, n 12, 2012. p. 283326.

O princípio da subsidiariedade e a redefinição do papel do estado no Brasil in Revista CEJ v. 615, Rio de Janeiro: América do Norte, 2008.

.O Controle de Licitações e Contratos Administrativos pelos Tribunais de Contas in Revista de Direito da Procuradoria Geral do Estado do Rio de Janeiro, n. 64. Rio de Janeiro: CEJUR, 2009

ZAGREBELSKY, Gustavo. El derecho dúctil. Ley, Derechos, Justicia, trad. Mariana Gascón. Madrid: Editorial Trotta, 2011. 